\title{
Conservation status of freshwater mussels in Europe: state of the art and future challenges
}

Manuel Lopes-Lima ${ }^{1,2, \dagger, *}$, Ronaldo Sousa ${ }^{1,3, \dagger}$, Juergen Geist ${ }^{4, \dagger}$, David C. Aldridge ${ }^{5}$, Rafael Araujo $^{6}$, Jakob Bergengren ${ }^{7}$, Yulia Bespalaya ${ }^{8}$, Erika Bódis ${ }^{9}$, Lyubov Burlakova $^{10}$, Dirk Van Damme ${ }^{11}$, Karel Douda ${ }^{12}$, Elsa Froufe ${ }^{1}$, Dilian Georgiev ${ }^{13}$, Clemens Gumpinger ${ }^{14}$, Alexander Karatayev ${ }^{10}$, Ümit Kebapçi ${ }^{15}$, Ian Killeen ${ }^{16}$, Jasna Lajtner $^{17}$, Bjørn M. Larsen ${ }^{18}$, Rosaria Lauceri ${ }^{19}$, Anastasios Legakis ${ }^{20}$, Sabela Lois ${ }^{21}$, Stefan Lundberg ${ }^{22}$, Evelyn Moorkens ${ }^{16}$, Gregory Motte ${ }^{23}$, Karl-Otto Nagel ${ }^{24}$, Paz Ondina $^{21}$, Adolfo Outeiro ${ }^{21}$, Momir Paunovic ${ }^{25}$, Vincent Prié ${ }^{26,27}$, Ted von Proschwitz $^{28}$, Nicoletta Riccardii ${ }^{19}$, Mudīte Rudzīte ${ }^{29}$, Māris Rudzītiss ${ }^{30}$, Christian Scheder $^{14}$, Mary Seddon ${ }^{2}$, Hülya Şereflişan ${ }^{31}$, Vladica Simić ${ }^{32}$, Svetlana Sokolova ${ }^{8}$, Katharina Stoeckl $^{4}$, Jouni Taskinen ${ }^{33}$, Amílcar Teixeira ${ }^{34}$, Frankie Thielen ${ }^{35}$, Teodora Trichkova $^{36}$, Simone Varandas ${ }^{37}$, Heinrich Vicentini ${ }^{38}$, Katarzyna Zajac ${ }^{39}$, Tadeusz Zajac $^{39}$ and Stamatis Zogaris ${ }^{40}$

${ }^{1}$ Interdisciplinary Centre of Marine and Environmental Research (CIIMAR/CIMAR), University of Porto, Rua dos Bragas 289, 4050-123 Porto, Portugal

${ }^{2}$ IUCN SSC Mollusc Specialist Group, c/o 219 Huntingdon Road, Cambridge CB3 ODL, U.K.

${ }^{3}$ Centre of Molecular and Environmental Biology (CMBA), University of Minho, Campus de Gualtar, 4710-057 Braga, Portugal

${ }^{4}$ Aquatic Systems Biology Unit, Department of Ecology and Ecosystem Management, Technische Universität München, Mühlenweg 22, 85350

Freising, Germany

${ }^{5}$ Aquatic Ecology Group, Department of Zoology, University of Cambridge, Downing Street, Cambridge CB2 3EJ, U.K.

${ }^{6}$ Museo Nacional de Ciencias Naturales-CSIC, C/Fosé Gutiérrez Abascal 2, 28006 Madrid, Spain

${ }^{7}$ Water Unit, County Administration Board Fönköping, SE-551 86 Jönköping, Siveden

${ }^{8}$ Institute of Ecological Problems of the North of Ural Branch of Russian Academy of Sciences, 163000 Arkhangelsk, Russia

${ }^{9}$ MTA Centre for Ecological Research, Danube Research Institute, Fávorka S. u. 14, 2131 Göd, Hungary

${ }^{10}$ Great Lakes Center, Buffalo State College, 1300 Elmwood Ave., Buffalo, NY 14222 U.S.A.

${ }^{11}$ Research Unit Palaeontology, Geological Institute, Universiteit Gent, Krijgslaan 281 (S8-B), B-9000 Gent, Belgium

${ }^{12}$ Department of Zoology and Fisheries, Faculty of Agrobiology Food and Natural Resources, Czech University of Life Sciences Prague, Kamycka 129, Prague CZ 165, Czech Republic

${ }^{13}$ Department of Ecology and Environmental Conservation, University of Plovdiv, Tzar Assen Str. 24, BG-4000 Plovdiv, Bulgaria

${ }^{14}$ Consultants in Aquatic Ecology and Engineering (Technisches Büro für Gewässerökologie) - Blattfisch, Gabelsbergerstraße 7, 4600 Wels, Austria

${ }^{15}$ Biology Department of Art and Science Faculty, Mehmet Akif Ersoy University, Burdur, Turkey

${ }^{16}$ 123, Rathdown Park, Greystones, County Wicklow, Ireland

${ }^{17}$ Department of Zoology, Division of Biology, Faculty of Science, University of Zagreb, Rooseveltov trg 6, HR-10000 Zagreb, Croatia

${ }^{18}$ Norwegian Institute for Nature Research (NINA), PO Box 5685 Sluppen, NO-7485 Trondheim, Norway

${ }^{19}$ CNR ISE - Institute of Ecosystem Study, Largo Tonolli 50, 28922 Verbania, Italy

${ }^{20}$ Zoological Museum, Department of Biology, University of Athens, Athens, Greece

${ }^{21}$ Departamento de Zooloxí e A.F., Fac. Veterinaria, Universidade de Santiago de Compostela (USC), 27002 Lugo, Spain

${ }^{22}$ Swedish museum of Natural History, PO Box 50007, SE-104 05 Stockholm, Sweden

${ }^{23}$ CRNFB - Centre de Recherche de la Nature, des Forêts et du Bois, Gembloux, Belgium

${ }^{24}$ Senckenberg Forschungsinstitut und Naturmuseum Frankfurt, Abteilung Marine Zoologie/Sektion Malakologie, Senckenberganlage 25, 60325

Frankfurt/Main, Germany

*Address for correspondence (Tel: +351223401800; E-mail: lopeslima.ciimar@gmail.com).

$\dagger$ These authors made equal contributions to this work. 
${ }^{25}$ Institute for Biological Research 'Sinisa Stankovic', University of Belgrade, 142 Bulevar despota Stefana, 11000 Belgrade, Serbia

${ }^{26}$ Equipe 'Exploration de la Biodiversité', USM 603/UMR 7138 'Systématique, Adaptation, Evolution', Muséum National d'Histoire Naturelle, Case Postale 51, 55, Rue Buffon, 75231 Paris Cedex 05, France

${ }^{27}$ Biotope, 22 Bd Maréchal Foch, 34140 Mèze, France

${ }^{28}$ Göteborg Natural History Museum, Invetebrate Zoology, Box 7283, 40235 Göteborg, Sweden

${ }^{29}$ Museum of Zoology, University of Latvia, Kronvalda Bulv. 4, Riga, LV-1586 Latvia

${ }^{30}$ Museum of Geology, University of Latvia, Alberta 10, Riga, LV-1010 Latvia

${ }^{31}$ Faculty of Marine Sciences and Technology, Mustafa Kemal University, 31200 Iskenderun, Hatay, Turkey

${ }^{32}$ Department of Hydroecology and Water Protection, Faculty of Science, Institute of Biology and Ecology, University of Kragujevac, 34000 Kragujevac, Serbia

${ }^{33}$ Department of Biological and Environmental Science, University of Jyväskylä, PO Box 35 (YAC-315.2), FI-40014 Jyväskylä, Finland

${ }^{34}$ CIMO - Mountain Research Centre, School of Agriculture, Polytechnic Institute of Bragança, Campus de Santa Apolónia, Apartado 1172, 5301-854 Bragança, Portugal

${ }^{35}$ Natur \& Ëmwelt/Fondation Hëllef fir d'Natur, Kierchestrooss 2, L-9753 Heinerscheid, Luxembourg

${ }^{36}$ Institute of Biodiversity and Ecosystem Research, Bulgarian Academy of Sciences, 2 Gagarin Str., Sofia, 1113 Bulgaria

${ }^{37}$ CITAB - Centre for Research and Technology of Agro-Environment and Biological Sciences, Forestry Department, University of Trás-os-Montes and Alto Douro, Apartado 1013, 5001-811 Vila Real, Portugal

${ }^{38}$ Gewässerökologie Wasserschöpfi, 488055 Zurich, Switzerland

${ }^{39}$ Institute of Nature Conservation, Polish Academy of Sciences, 31-120 Kraków, Mickiewicza 33, Poland

${ }^{40}$ Hellenic Centre For Marine Research - Institute of Marine Biological Sciences and Inland Waters, 46, $7 \mathrm{~km}$ Athens-Sounio, Anavissos, Attiki, Greece

\section{ABSTRAGT}

Freshwater mussels of the Order Unionida provide important ecosystem functions and services, yet many of their populations are in decline. We comprehensively review the status of the 16 currently recognized species in Europe, collating for the first time their life-history traits, distribution, conservation status, habitat preferences, and main threats in order to suggest future management actions. In northern, central, and eastern Europe, a relatively homogeneous species composition is found in most basins. In southern Europe, despite the lower species richness, spatially restricted species make these basins a high conservation priority. Information on freshwater mussels in Europe is unevenly distributed with considerable differences in data quality and quantity among countries and species. To make conservation more effective in the future, we suggest greater international cooperation using standardized protocols and methods to monitor and manage European freshwater mussel diversity. Such an approach will not only help conserve this vulnerable group but also, through the protection of these important organisms, will offer wider benefits to freshwater ecosystems.

Key words: biology, ecology, Europe, freshwater bivalves, naiads, Margaritiferidae, Unionidae.

\section{CONTENTS}

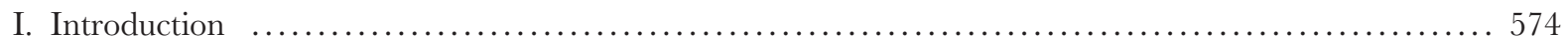

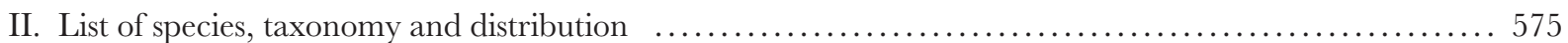

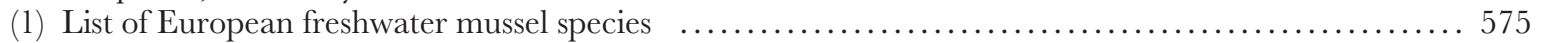

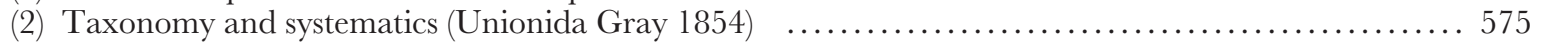

(a) Family Margaritiferidae Henderson 1929 (1910) $\quad$.................................... 575

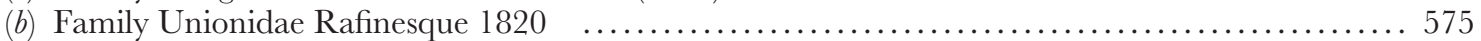

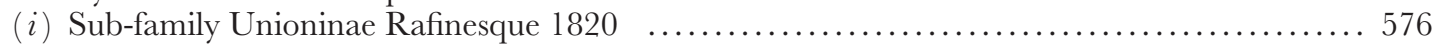

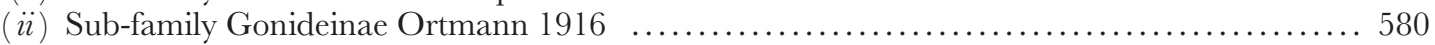

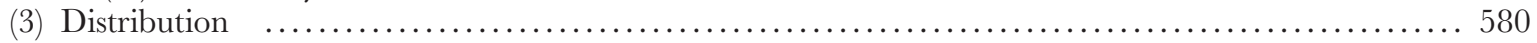

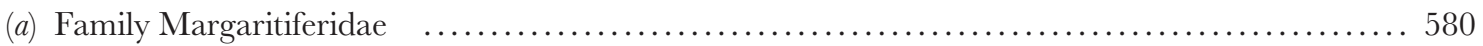

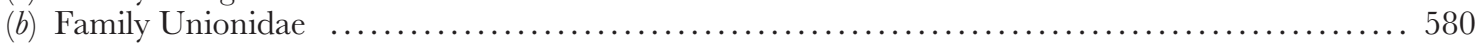

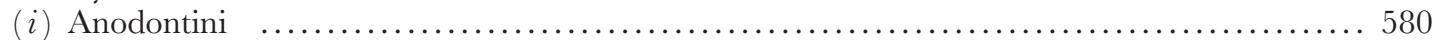

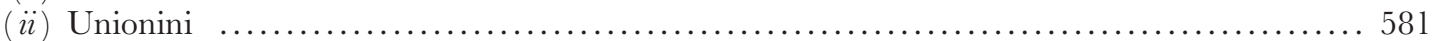

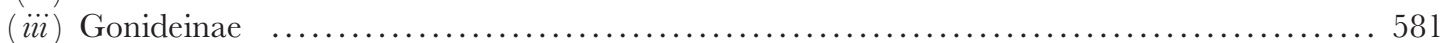

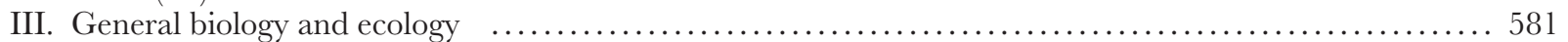

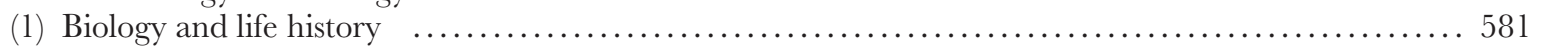




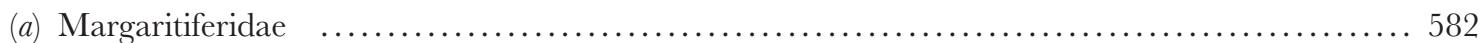

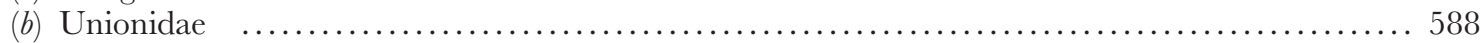

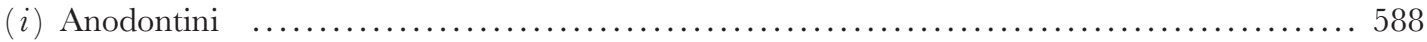

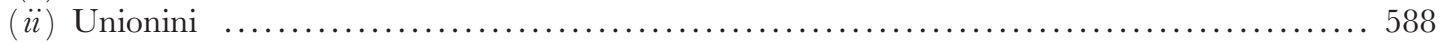

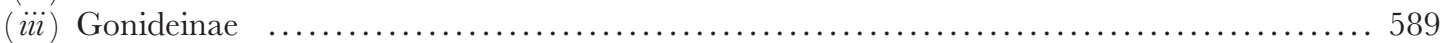

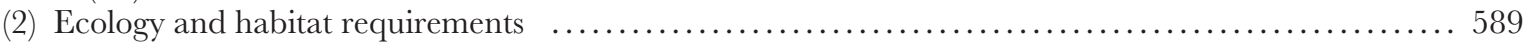

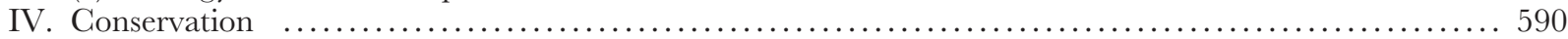

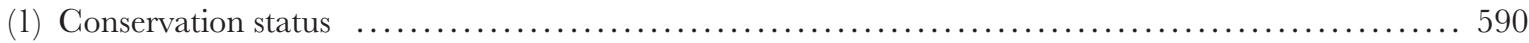

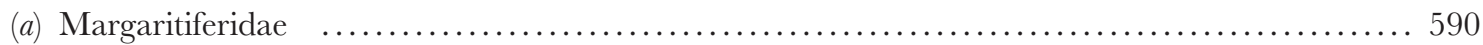

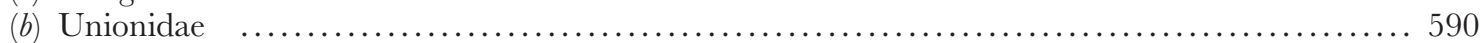

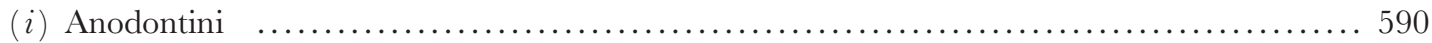

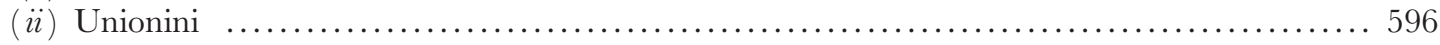

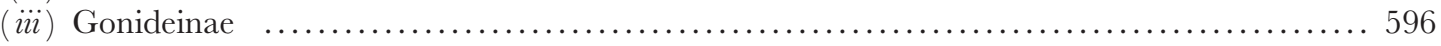

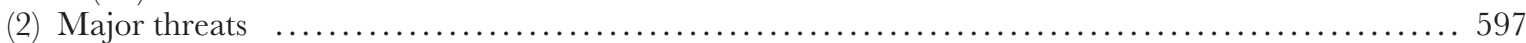

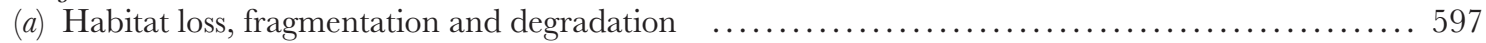

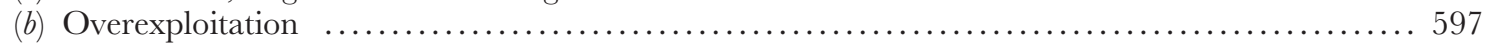

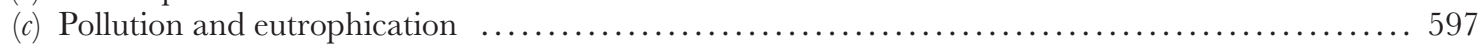

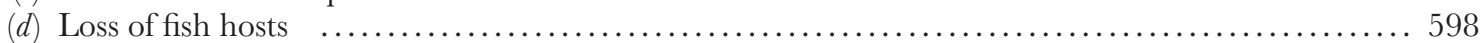

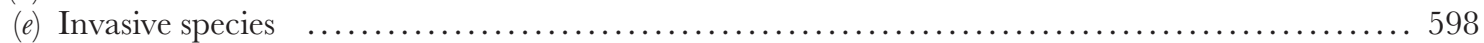

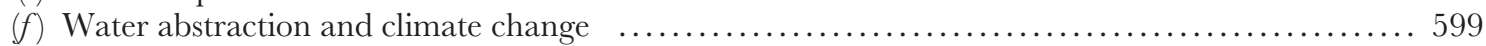

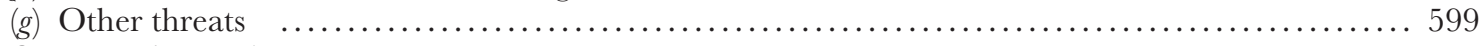

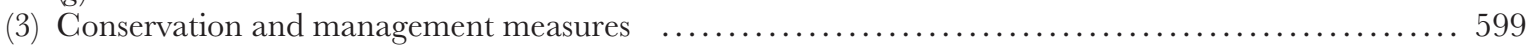

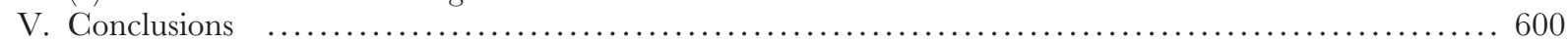

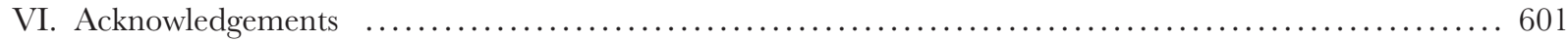

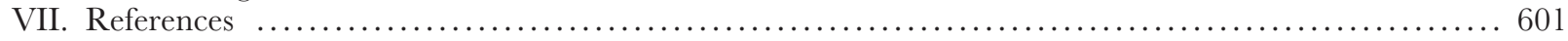

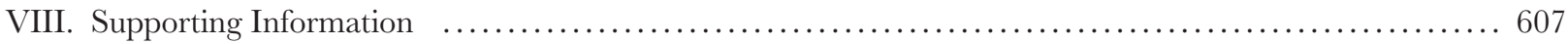

\section{INTRODUCTION}

Freshwater bivalves of the Order Unionida Gray 1854, also known as freshwater mussels, freshwater clams or naiads, are remarkable organisms. They may live for over a century and their unique life history includes parental care (i.e. brooding) and larval parasitism on freshwater fishes (and occasionally other vertebrates) (Lopes-Lima etal., 2014c). Freshwater mussels are also important components of aquatic ecosystems (Vaughn \& Hakenkamp, 2001), sometimes constituting $>90 \%$ of the benthic biomass of rivers (Negus, 1966). An individual mussel is capable of filtering around 401 of water each day (Tankersley \& Dimock, 1993) and the combined filtration of a mussel population can account for approximately $50 \%$ of the observed seston retention in a river during the summer (Pusch, Siefert \& Walz, 2001). Their transfer of matter and energy from the water column to the benthos may have strong effects on primary and secondary production, biogeochemical cycles, sedimentation rates, and water clarity (Strayer et al., 1999). In addition, their shells function as an important substrate for many other organisms (Vaughn \& Hakenkamp, 2001; Spooner et al., 2013). Because of their direct and indirect effects on fresh waters, mussels are often described as ecosystem engineers (Gutiérrez et al., 2003). Their key role in ecosystems is exemplified by the higher diversity of associated macroinvertebrates at sites which carry higher densities of mussels (Aldridge, Fayle \& Jackson, 2007). Freshwater mussels also provide important direct services to humans, such as water purification, serving as important prey for several commercial fishes, providing a direct source of protein, and providing valuable materials such as shells and pearls (Haag, 2012).

Mussels are declining precipitously worldwide (Strayer et al., 2004). For example, 224 (44\%) of the 511 freshwater mussel species are classified as Near Threatened or Threatened in the 2015 IUCN Red List of Threatened Species. Much of the global awareness of freshwater mussel declines stems from North American Unionida, which constitute the continent's most imperilled fauna (Williams et al., 1993; Strayer etal., 2004). Over 70\% of North American species are considered imperilled at some level (Williams etal., 1993) and 37 species are presumed extinct (Lydeard et al., 2004).

In recent years, Europe's freshwater mussels have also received increasing attention. More rivers and lakes are being surveyed and molecular techniques are helping to discern phylogenies and resolve synonymies. Increased international collaboration is revealing widespread and rapid declines at the regional level (Sousa etal., 2008; Geist, 2010; Prié, Molina \& Gamboa, 2014). Despite this increasing awareness, conservation has focused on a handful of species, such as Unio crassus Philipsson 1788, and the pearl mussels Margaritifera margaritifera (Linnaeus 1758) and Margaritifera auricularia (Spengler 1793). Some populations of these species have disappeared within living memory or have been reduced to small, localized, non-recruiting populations (e.g. Araujo \& Ramos, 2001). Considerably less attention has been paid to the other European Unionida mussels, and this probably reflects the assumption that they are widespread, 
abundant and recruiting. The absence of baseline data makes the quantification of population change challenging, and the recent discoveries of new populations of some species can even give the impression of population increase (Aldridge, 2004).

To date, no publication has attempted to synthesize our collective understanding of the ecology, distribution, and conservation status of the European freshwater mussel species. To address this, we have assembled the knowledge and expertise of malacologists from across Europe to (i) list the presently accepted European Unionida species and discuss their taxonomy; (ii) characterize their distribution; (iii) describe their basic biological characteristics and habitat preferences highlighting research gaps on life history and their functional role; $(i v)$ assess their conservation status; (v) summarize the major threats to these species and highlight the critical knowledge gaps that impair conservation efforts; and $(v i)$ suggest a logical path for future work.

\section{LIST OF SPEGIES, TAXONOMY AND DISTRIBUTION}

\section{(1) List of European freshwater mussel species}

In the early 1900s, European mussel diversity was grossly overestimated (about 1500 species) due to numerous synonyms applied to variable shell forms, particularly by the French Ecole Nouvelle (Graf, 2010). By the end of the 20th century many synonymies had been resolved, merging the previous descriptions into 12 recognized species with several subspecies (e.g. Germain, 1931; Haas, 1969; Araujo \& de Jong, 2015). In recent years, this number has increased reflecting molecular advances in taxonomy (Araujo, Toledo \& Machordom, 2009b; Reis \& Araujo, 2009; Prié, Puillandre $\&$ Bouchet, 2012) and will likely continue to increase as more research efforts are made in this field (Graf, 2010). Currently, 16 species of European Unionida are recognized (Figs 1 and 2). Based on this recent work, we present a revised checklist of the European Unionida species (Table 1, see also online supporting information, Appendix S1).

\section{(2) Taxonomy and systematics (Unionida Gray 1854)}

The order Unionida is represented in Europe by two families: (i) the Margaritiferidae Henderson 1929 (1910), which comprises only two species: $M$. auricularia and $M$. margaritifera and; (ii) the Unionidae, represented by 14 species in five genera (Anodonta Lamarck 1799; Microcondylaea Vest 1866; Potomida Swainson 1840; Pseudanodonta Bourguignat 1877; and Unio Philipsson 1788).

\section{(a) Family Margaritiferidae Henderson 1929 (1910)}

In Unionida phylogeny, the Margaritiferidae was regarded until recently as the most basal family due to the lack of more specialized anatomical features (Bogan \& Roe, 2008). However, molecular studies place margaritiferids as sister to (or nested within) the Unionidae (Hoeh etal., 2002; Graf \& Cummings, 2006). The interspecific relationships within the Margaritiferidae have also remained contentious. Using mainly conchological and anatomical characters, Smith (2001) divided the family into three genera: Margaritifera Schumacher 1816, Margaritanopsis Haas 1912, and Pseudunio Haas, 1910. However, a study using molecular techniques indicated polyphyly in these genera, and instead suggested that the genus Margaritifera should encompass all margaritiferid species (Huff et al., 2004).

Although distinct evolutionary lineages or subspecies of M. margaritifera have been described [e.g. M. m. durrovensis Philips 1928 and M. m. brunnea (Bonhomme 1840)], these are not supported by molecular data (Fig. 1; Chesney, Oliver \& Davis, 1993; Machordom et al., 2003). Within the species, a gradient in genetic diversity is evident, with higher variation observed in northern than in south-western Europe (Geist \& Kuehn, 2005; Geist et al., 2010b). The pronounced genetic structure across $M$. margaritifera populations may reflect reproductive isolation (Geist \& Kuehn, 2005) and/or differentiation according to use of different host fishes (Salmo trutta or Salmo salar) (Karlsson, Larsen \& Hindar, 2014).

The generic affiliation of $M$. auricularia has been controversial. This species was allocated to the genus Pseudunio to distinguish it from M. margaritifera (Haas, 1910) and 1 year later re-synonymized with Margaritifera (Ortmann, 1911). Pseudunio was subsequently resurrected as a subgenus to distinguish $M$. auricularia and its subspecies $M$. a. marocana Pallary 1918 from the remaining Margaritifera species (Haas, 1969). Since then, Pseudunio was used again as a genus based on morphological characters (Smith, 2001; Nienhuis, 2003). The first comprehensive phylogenetic study on margaritiferids, using nuclear and mitochondrial molecular data, associated M. auricularia with the North American Margaritifera monodonta (Huff etal., 2004). However, this association was not well supported and the mitochondrial data alone presented an alternative pattern dividing both species into separate lineages. More recent molecular studies showed that although both $M$. auricularia and the re-described North African $M$. marocana form a monophyletic clade (Araujo et al., 2009c), the use of Pseudunio as either a genus or subgenus is not supported (Araujo et al., 2009a).

\section{(b) Family Unionidae Rafinesque 1820}

The family Unionidae is represented in Europe by two subfamilies: Unioninae and Gonideinae (Graf \& Cummings, 2015). Within the Unioninae, the European species are divided into two tribes: $(i)$ the Anodontini, including two Anodonta species and Pseudanodonta complanata (Rossmässler 1835) and (ii) the Unionini, which comprises all Unio species. In the Gonideinae, two species are recognized: Potomida littoralis (Cuvier 1798) and Microcondylaea bonellii (A. Ferussac 1827), both restricted to southern Europe. Although preliminary molecular data support their presence in Gonideinae (E. Froufe \& M. Lopes-Lima, unpublished data), the monophyly of this subfamily remains 


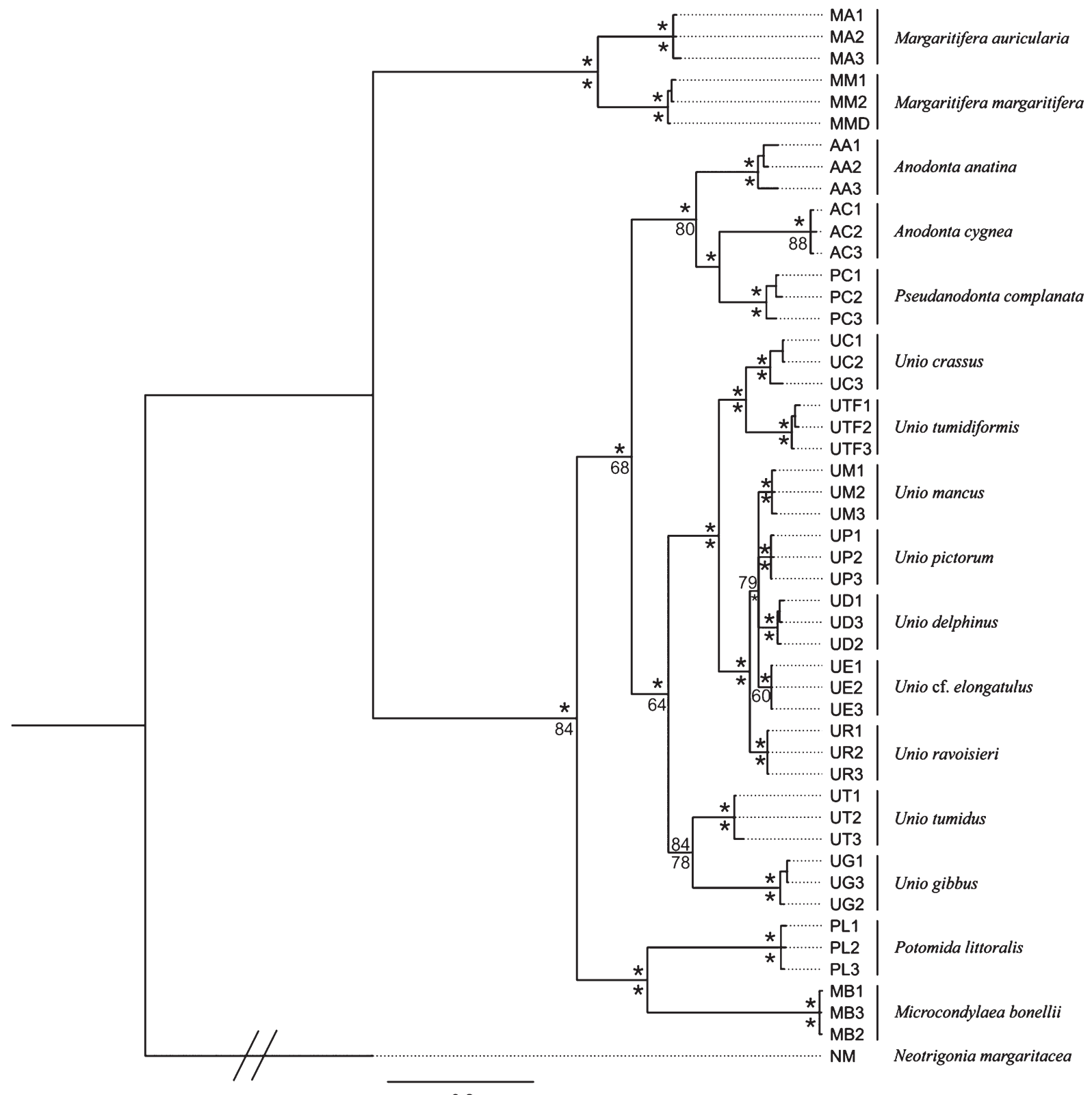

0.2

Fig. 1. Phylogenetic tree obtained by Bayesian inference analysis using the GTR $+\mathrm{I}+\mathrm{G}$ model and maximum likelihood (ML) using the TPM2uf $+\mathrm{I}+\mathrm{G}$ model of the combined mtDNA fragments [cytochrome oxidase subunit I (COI) and 16S]. Support values are given as Bayesian posterior probability above nodes and as bootstrap support below nodes, except for those with values below 50 and within the species level, which have been omitted for clarity. Values above 90 are represented by*. The tree topologies resulting from ML and BI approaches were congruent. The tree was rooted with Neotrigonia margaritacea. See Appendix S1 and Table S1 for available sequences downloaded from GenBank and new sequence codes.

uncertain and further studies are needed to clarify their status.

(i) Sub-family Unioninae Rafinesque 1820. Tribe Anodontini Rafinesque 1820. The number of Anodonta species in Europe was unclear and their taxonomy in disarray until the middle of the 20th century when all species were merged into the single taxon Anodonta cygnea (Linnaeus 1758) (Haas, 1969). Since then, an additional species, Anodonta anatina (Linnaeus 1758), is recognized (Fig. 1; Nagel, Badino \& Celebrano,
1998; Araujo etal., 2009a). The high plasticity (Zieritz \& Aldridge, 2011) and similarity of some morphotypes can make visual distinction between Anodonta species extremely difficult, with molecular identification keys producing more reliable results (Källersjö etal., 2005; Zieritz etal., 2012). A study of the cytochrome oxidase I (COI) mitochondrial gene of Anodontini from across Europe identified three clades of $A$. anatina, but recognised only two species (A. anatina and A. cygnea; Froufe et al., 2014). Nagel, Badino 


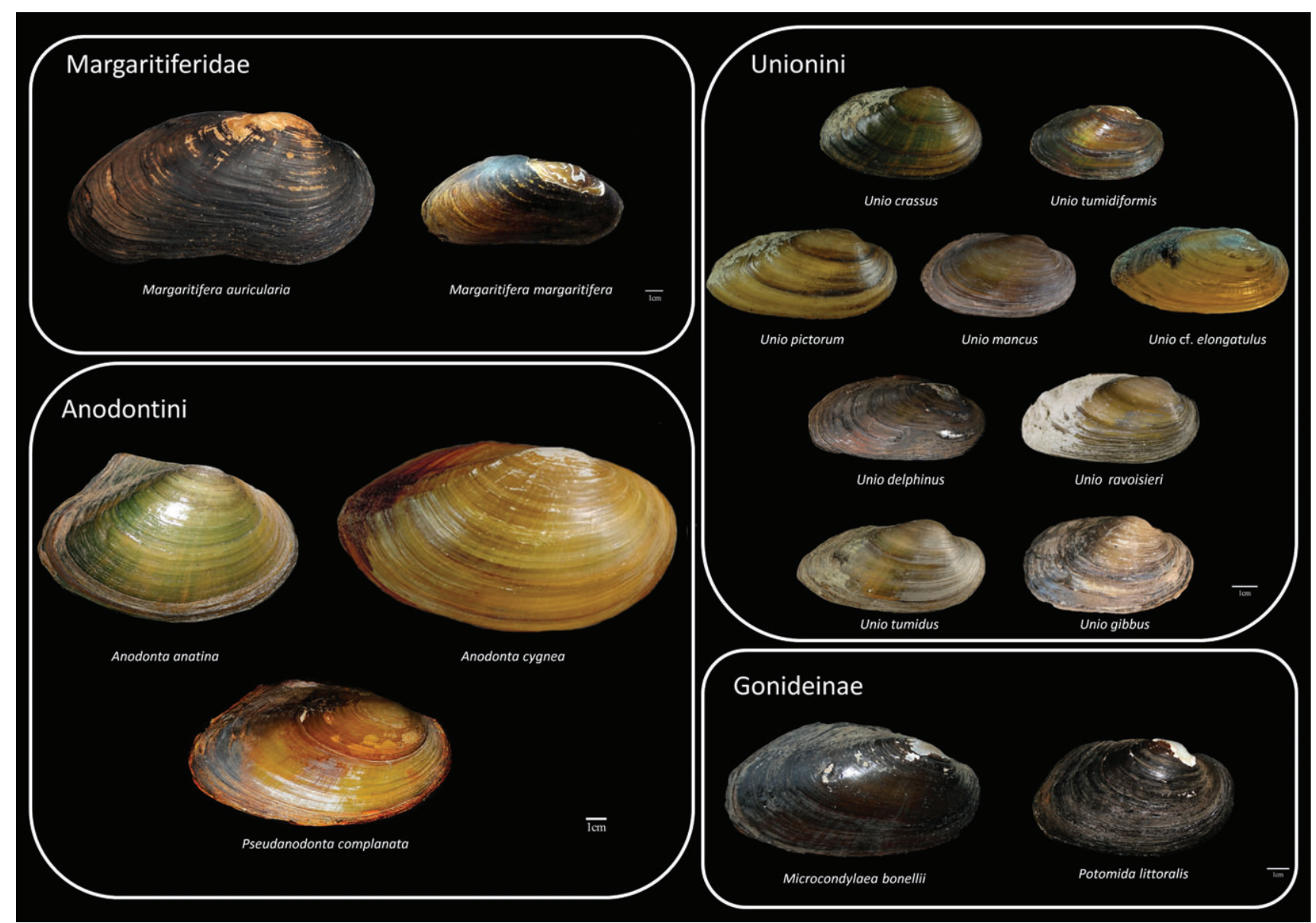

Fig. 2. Shells of representative freshwater mussel taxa in Europe.

\& Alessandria (1996) suggested that some populations of Anodonta in Italy and Switzerland belong to one or two additional lineages and this warrants further investigation; however, no Anodonta subspecies are currently accepted.

The phylogeny and taxonomy of $P$. complanata remains unresolved. Some studies recognize three geographically separated species in Europe: $P$. complanata; $P$. elongata Holandre 1836 and P. middendorffi (Siemaschko 1849), the latter comprising two subspecies (Haas, 1969; Araujo \& de Jong, 2015). Additional Pseudanodonta taxa are also included in other regional checklists (e.g. Kantor et al., 2010). However, Pseudanodonta has not been subject to rigorous genetic studies across its distribution, and its taxonomic status is unclear. Because these issues are unresolved we follow traditional usage and recognize Pseudanodonta as containing a single species, P. complanata (e.g. Graf, 2007; Skidmore et al., 2010).

Tribe Unionini Rafinesque 1820. The genus Unio in Europe is divided into four main lineages: crassus, pictorum, tumidus and gibbus (Table 1; Fig. 1). This division is based on the most recent molecular data (Araujo etal., 2009a; Reis \& Araujo, 2009; Khalloufi etal., 2011; Prié etal., 2012; Prié \& Puillandre, 2014) although further research is needed to enlighten inter- and intraspecific relationships.
$U$. crassus lineage - the crassus lineage was recently divided into two species, U. crassus and Unio tumidiformis Castro 1885 (Reis \& Araujo, 2009). Within U. crassus sensu stricto, several subspecies have been recognized (e.g. Haas, 1969; Kantor etal., 2010; Araujo \& de Jong, 2015), but the validity of most is unknown (see Table 1). Unio c. courtillieri was recently confirmed as a distinct lineage based on $16 \mathrm{~S}$ and COI gene fragments (Prié \& Puillandre, 2014). In this study, we recognize only $U$. tumidiformis and two subspecies within $U$. crassus, $U$. c. crassus and $U$. c. courtillieri, but other previously described subspecies deserve further attention (see Table 1).

$U$. pictorum lineage - over the last decade, the pictorum lineage has been divided into Unio pictorum (Linnaeus 1758), Unio mancus Lamarck 1819, Unio delphinus Spengler 1793, and Unio ravoisieri Deshayes 1848 (Araujo, Gómez \& Machordom, 2005; Araujo etal., 2009b; Khalloufi etal., 2011; Reis, Machordom \& Araujo, 2013). In addition, a number of subspecies have been described (Haas, 1969; Araujo \& de Jong, 2015), but the validity of most remains uncertain (e.g. Prié \& Puillandre, 2014). Despite the nomenclatural priority of mancus over elongatulus, some authors have not considered U. mancus as a valid species (e.g. Haas, 1969). Instead, they have placed $U$. mancus under the name $U$. elongatulus 


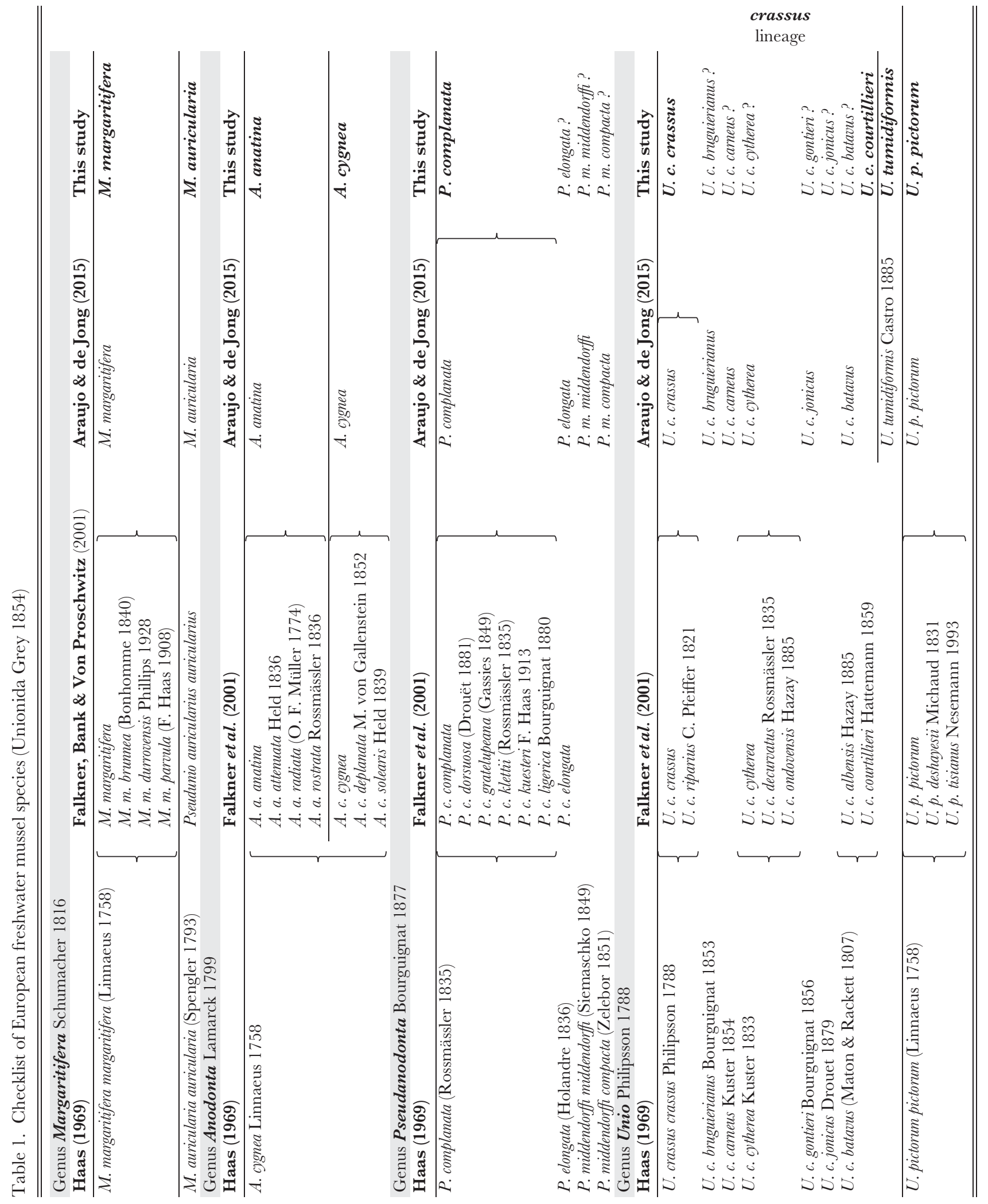




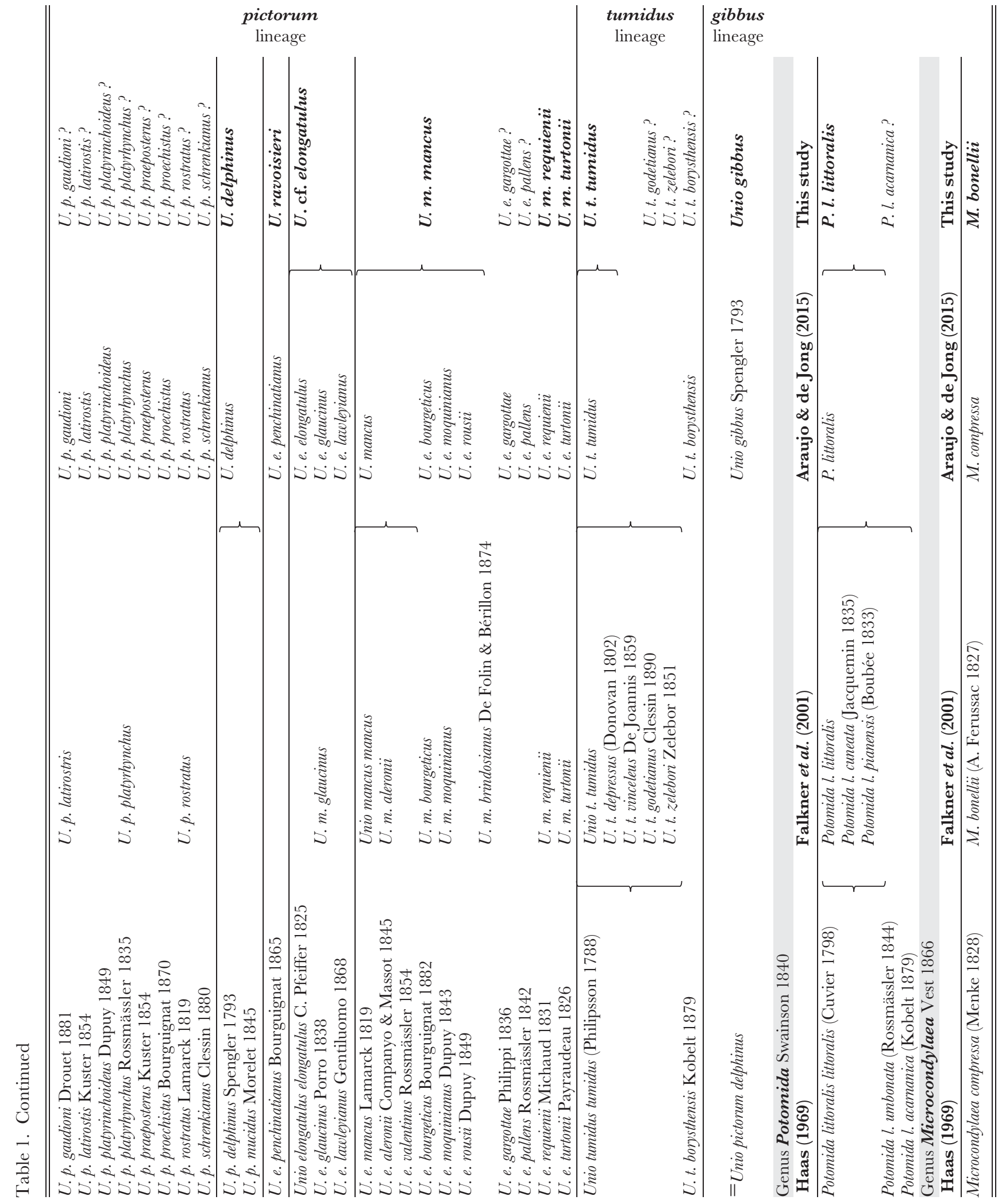


(Haas, 1969). However, in recent years these lineages have been consensually reassigned to $U$. mancus (Araujo etal., 2005; Prié et al., 2012). Recent molecular studies revealed three genetically distinct subspecies within $U$. mancus in Spain and France: $U$. m. mancus, U. m. requienii, and $U$. m. turtonii (Araujo et al., 2005; Prié et al., 2012). Additionally, a population from northern Italy is genetically divergent from French and Spanish U. mancus and is referred to as Unio cf. elongatulus following Prié \& Puillandre (2014). The status of two previously described subspecies of the elongatulus/mancus complex, U. e. gargottae and U. e.pallens, still need validation.

The species $U$. ravoisieri and $U$. delphinus were once included within U. elongatulus and U. pictorum, respectively (Haas, 1969). Both species were recently shown to be distinct, based on molecular, reproductive and morphological characters (Araujo etal., 2009a; Khalloufi etal., 2011). Within the $U$. pictorum lineage we recognise five species: $U$. pictorum, $U$. delphinus, $U$. ravoisieri, $U$. cf. elongatulus and $U$. mancus with three subspecies: U.m. mancus, U.m. requienii, and $U . m$. turtonii (Table 1).

$U$. tumidus lineage - relatively little attention has been paid to $U$. tumidus Philipsson 1788. Although subspecies have been described, recent molecular assessment of material from France did not support the assignment of any subspecies (Prié \& Puillandre, 2014; Table 1).

U. gibbus lineage - in Europe, this lineage includes only $U$. gibbus Spengler 1793, based on morphological, reproductive, and molecular characters (Araujo et al., 2009b).

(ii) Sub-family Gonideinae Ortmann 1916. Microcondylaea bonellii (A. Ferussac 1827) and Potomida littoralis (Cuvier 1798) were previously assigned to the North American subfamilies Ambleminae (Nagel etal., 1998) and Quadrulinae (Haas, 1940, 1969), respectively. Both species were later considered as incertae sedis (Graf \& Cummings, 2007). Subsequent studies placed them in the Gonideinae (Whelan, Geneva \& Graf, 2011), despite a lack of unequivocal support for the monophyly of the subfamily. In this study, both species are provisionally considered as part of the Gonideinae. In the present study, newly sequenced individuals associate $M$. bonelli with $P$. littoralis within the European Unionida (Fig. 1; see online Appendix S1).

$P$. littoralis was formerly divided into several subspecies, but molecular studies covering the Iberian Peninsula and France have detected no valid subspecies within this region (Araujo etal., 2009a). Populations of P. littoralis in Greece and Turkey show considerable isolation and are worthy of further taxonomic evaluation (Reis et al., 2013). However, based on the current evidence we recognize no subspecies under $P$. littoralis.

Very low genetic diversity was detected for $M$. bonellii populations from Italy using allozymes (Nagel \& Badino, 2001), but more research is needed from across its distribution to understand better the phylogeography of this species.

\section{(3) Distribution}

Data on the distribution of European freshwater mussels were derived from published distribution data, supplemented with information from the most recent surveys performed by the authors of this review (Figs 3-6; see online Appendix S2). For many European regions, there is a paucity of detailed surveys, and even scarcer are studies addressing possible changes in density, biomass or spatial distributions over time. There are also considerable differences in data quality and quantity across regions, with much more information available for France, Germany, Great Britain, Iberia and Scandinavia than for the Balkans and Eastern Europe. There is also an imbalance in data available for different species, with considerable detail on $M$. margaritifera, $M$. auricularia and $U$. crassus, but relatively little information for $P$. complanata, $M$. bonellii and $U$. cf. elongatulus.

Highest species richness per basin is found in central, northern, and eastern Europe (Fig. 7), but the freshwater mussel fauna of these regions is relatively homogeneous. By contrast, southern Europe is characterized by lower species richness per basin but a higher number of distribution-restricted species (e.g. M. bonellii and $U$. tumidiformis).

\section{(a) Family Margaritiferidae}

The genus Margaritifera is distributed discontinuously across Europe. The holarctic $M$. margaritifera has a wide distribution (Araujo \& Ramos, 2001; Young, Cosgrove \& Hastie, 2001; Geist, 2010) occurring in oligotrophic streams in northern and central Europe from the British Isles in the west to Norway in the north and northern Russia in the east. The species extends southwest to the northern Iberian Peninsula where it is found in the north-western Atlantic rivers (Fig. 3). While $M$. margaritifera is still found in most of its historical distribution, the species has disappeared from many streams and is now probably extinct in Belarus, Denmark, Lithuania, and Poland (Cuttelod, Seddon \& Neubert, 2011). M. auricularia was once widespread in western Europe. Ninetieth century historical records exist from the Iberian Peninsula to France, and the Po basin in Italy, but since the 20th century its distribution has been restricted to south-western France and the Ebro basin in Spain (Smith, 2001) (Fig. 3).

\section{(b) Family Unionidae}

The family Unionidae is present in all European countries including UK and Ireland (Haas, 1969).

(i) Anodontini. The two Anodonta species are distributed widely from the UK in the west to Russia in the east (Fig. 4A, B) and occur in all southern European countries. However, A. anatina has a much wider distribution than $A$. cygnea and can occupy a wider variety of habitats. $P$. complanata is present in most of northern and central Europe from the UK in the west to Russia in the east, but is not known from southern Europe (Fig. 4G). 


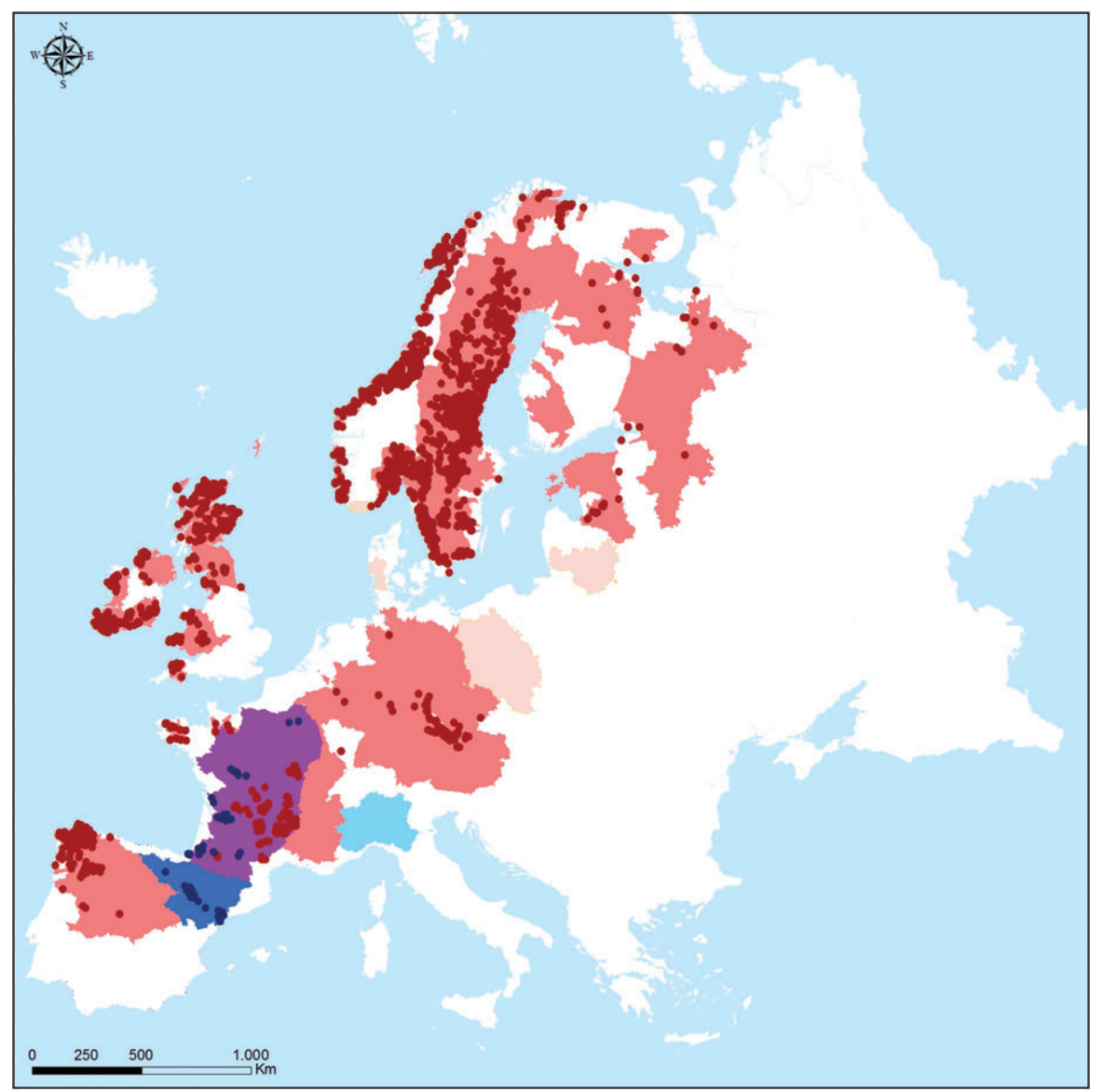

Fig. 3. Distribution of Margaritiferidae in Europe. Light shades correspond to historical distribution in hydrographical basins (prior to 1992), dark shades correspond to present distribution in hydrographical basins (after 1992) and dots represent present known populations (after 1992). Known distribution of Margaritifera auricularia (blue), M. margaritifera (red), and both (purple). Distribution data are based on recent surveys performed by the authors of this review and published distributions (see online Appendix S2).

(ii) Unionini. The genus Unio is present in all European countries. $U$. crassus is widely distributed in central, south-eastern and northern Europe from France in the west to Russia in the east (Fig. 5A). U. tumidiformis is present only in the south-west of the Iberian Peninsula (Fig. 5A). In the pictorum lineage, $U$. pictorum is the most widespread, being distributed in central, south-eastern and northern Europe from the British Isles in the west to Russia in the east (Fig. 5B). $U$. delphinus and $U$. ravoisieri are restricted to different regions of the Iberian Peninsula, with $U$. delphinus present in western Iberia and $U$. ravoisieri known from just two locations (River Ser and Lake Banyolas) in Catalonia (Araujo et al., 2009a) (Fig. 5C). U. mancus is present in Mediterranean Iberia, France (where it is possibly sympatric with $U$. pictorum), Italy and Croatia, where in the last two countries it may co-occur with $U$. cf. elongatulus (Fig. 5G). U. tumidus is also widespread with a distribution similar to $U$. pictorum, although $U$. tumidus has not been recorded from Ireland (Fig. 5D). U. gibbus, which is distributed through north-west Africa, was once widely present in southern Iberia but it is now restricted to the River Barbate near Cadiz in the south of Spain (Fig. 5D). (iii) Gonideinae. The two Gonideinae, M. bonellii and $P$. littoralis, have an interesting and non-overlapping distribution in southern Europe (Fig. 6). M. bonellii is present from the Italian Peninsula to the Adriatic drainages of the Balkans. By contrast, P. littoralis has a disjunct distribution in south-western Europe including Iberia and France to Greece and Turkey in the south-east, but eastern populations potentially represent a separate species (see Section II.2b.ii).

\section{GENERAL BIOLOGY AND EGOLOGY}

\section{(1) Biology and life history}

Freshwater mussels can be very long lived and possess a remarkable life history where the female mussel broods her eggs in a modified gill (the marsupium). Fertilization takes place across the gill surface with sperm entering the mantle cavity via the inhalant current. Fertilized eggs develop into a specialized larva (the glochidium), which must parasitize a host fish (or in rare cases other vertebrates) upon which it encysts and metamorphoses. This parasitic 

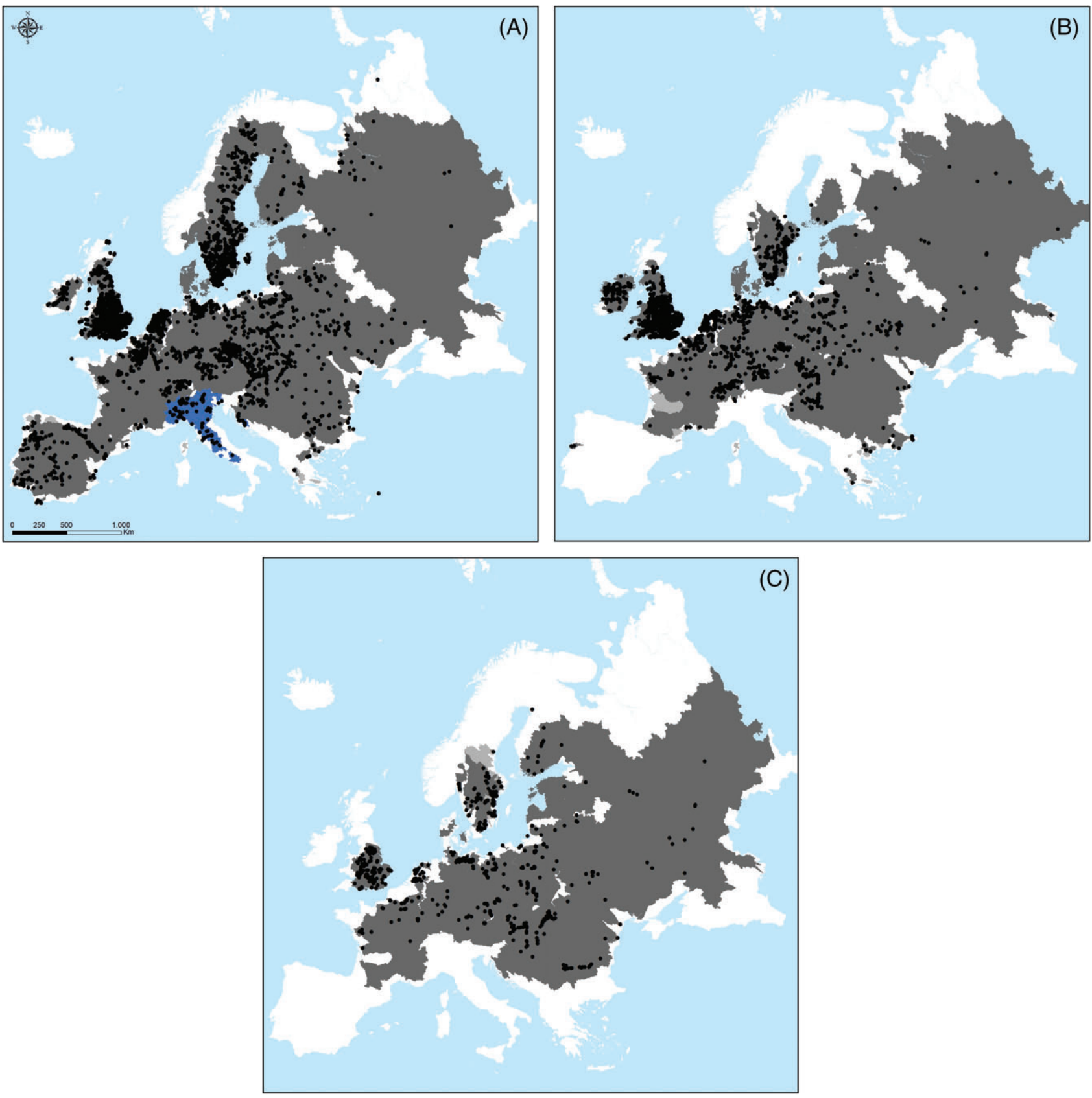

Fig. 4. Distribution of Anodontini in Europe. Light shades correspond to historical distribution in hydrographical river basins (prior to 1992), dark shades correspond to present distribution in hydrographical river basins (after 1992) and dots represent present known populations (after 1992). (A) Distribution of Anodonta anatina (grey) and Anodonta sp. (blue); (B) distribution of A. cygnea; (C) distribution of Pseudanodonta complanata. Distribution data are based on recent surveys performed by the authors of this review and published distributions (see online Appendix S2).

life stage may benefit the mussel through dispersal and provides a source of nutrients (Denic, Taeubert \& Geist, 2015). The brooding behaviour and selectivity of hosts varies among mussel species. A summary of life-history traits is given in Table 2 (see also online Appendix S3). Information on host fishes is poorly known for most mussel species and local adaptations to specific host populations can occur (e.g. Taeubert etal., 2010, 2012b; Karlsson etal., 2014).

\section{(a) Margaritiferidae}

Margaritiferids typically live for more than 80 years, reaching reproductive maturity at approximately 10 years of age (Table 2). Both European margaritiferids are short-term brooders (tachytictic), incubating the brood for 5-7 weeks in the four gill demibranchs (tetrabranchy). M. margaritifera is generally considered to be dioecious (Ziuganov et al., 1994) 


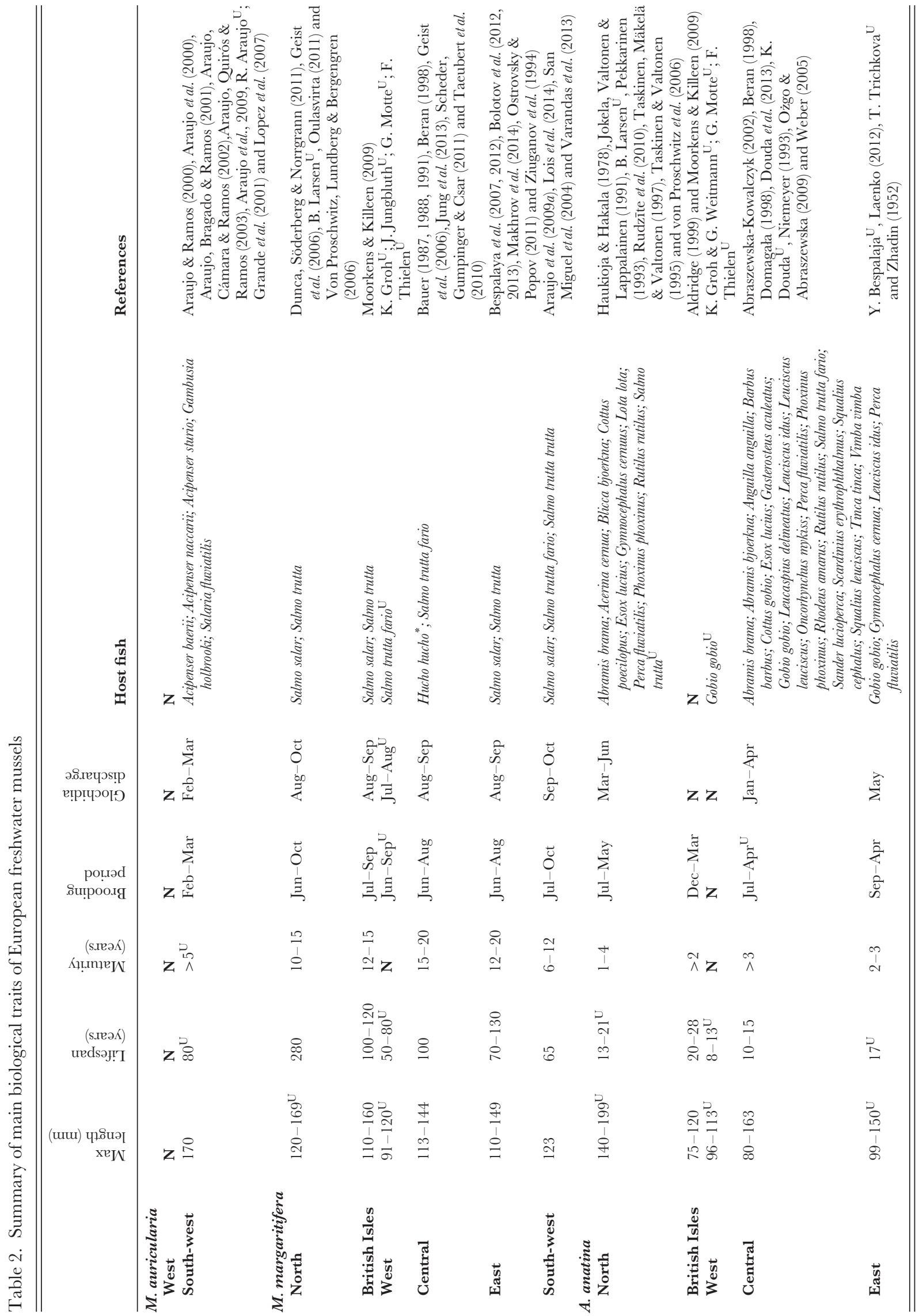




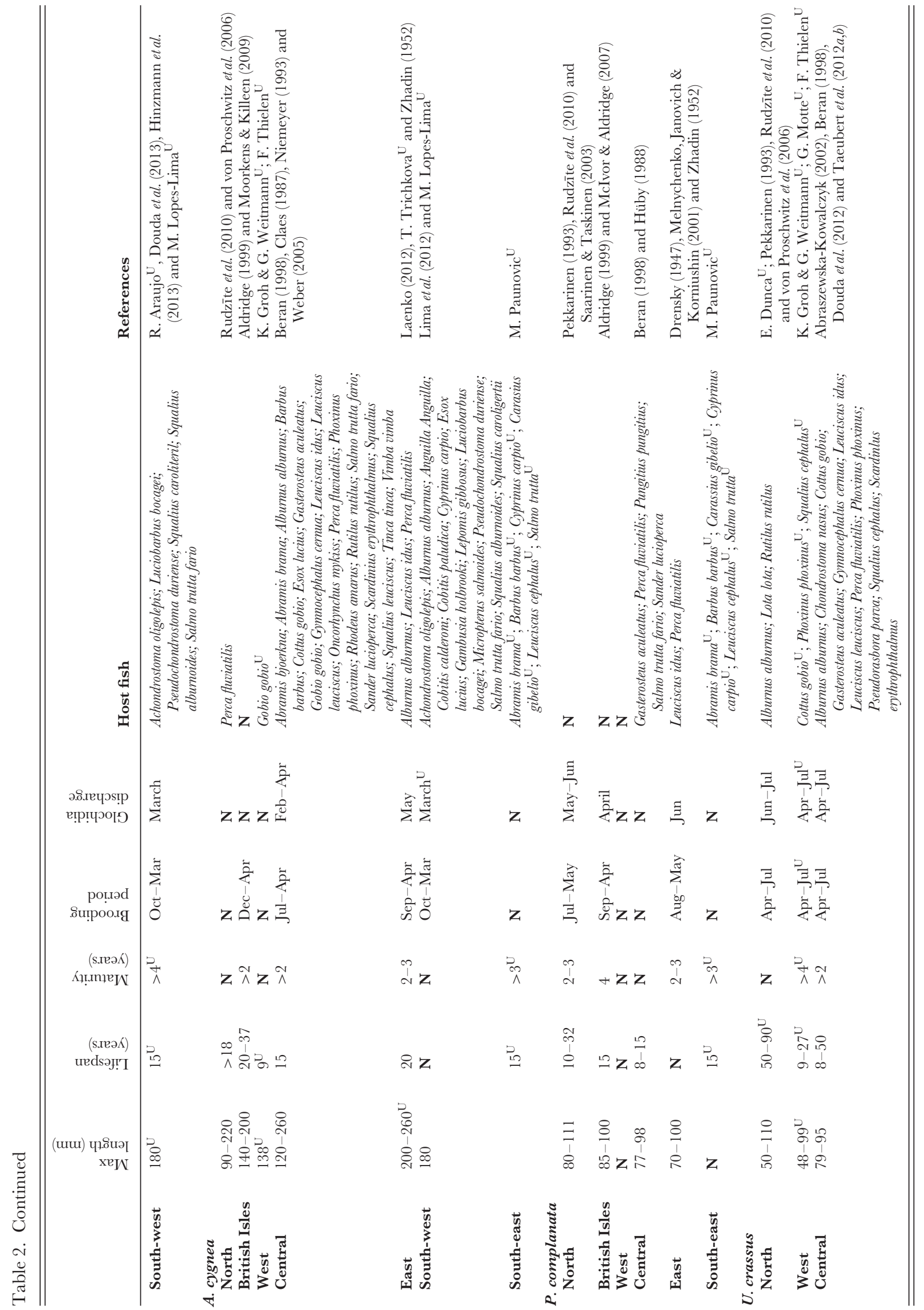




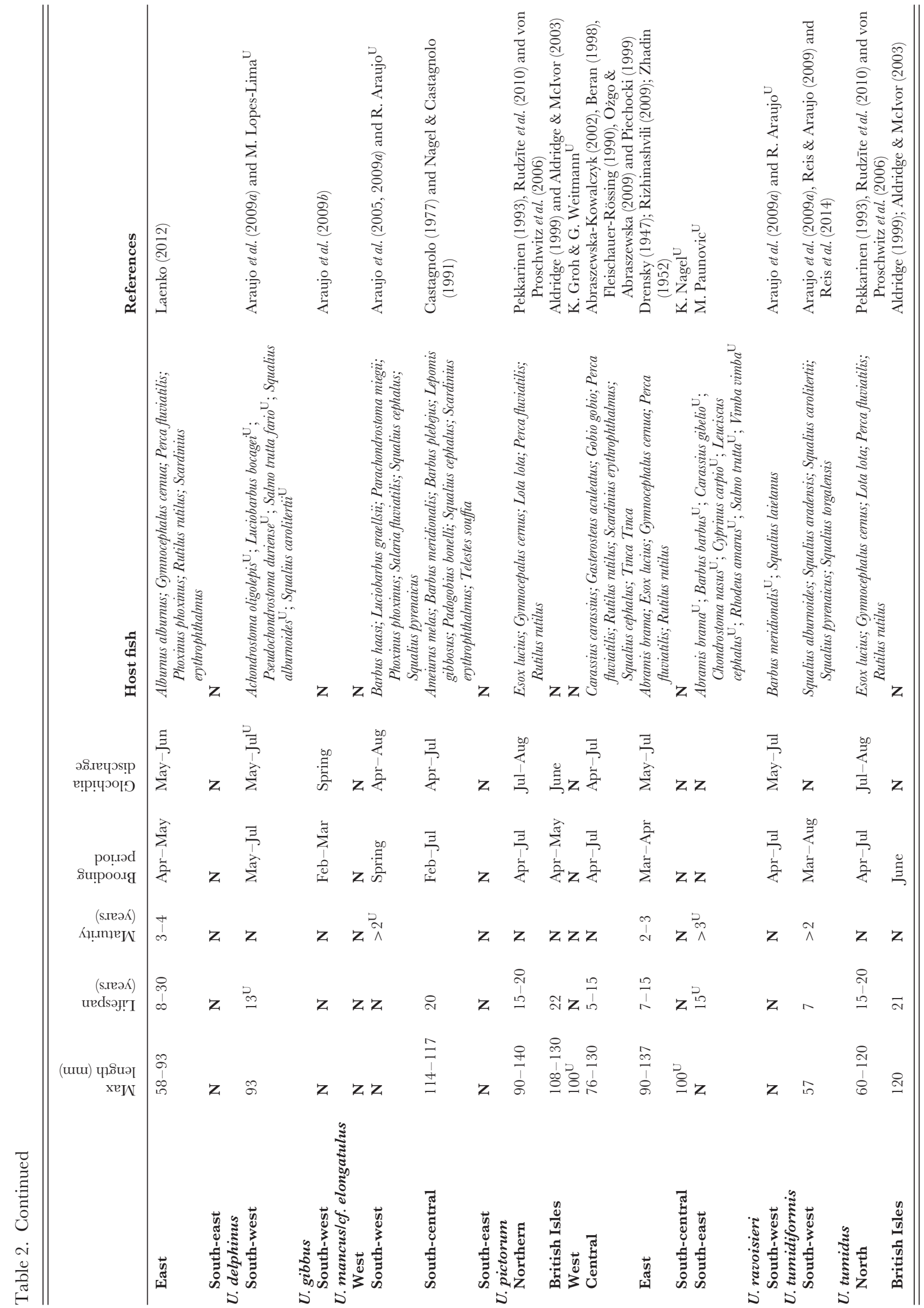




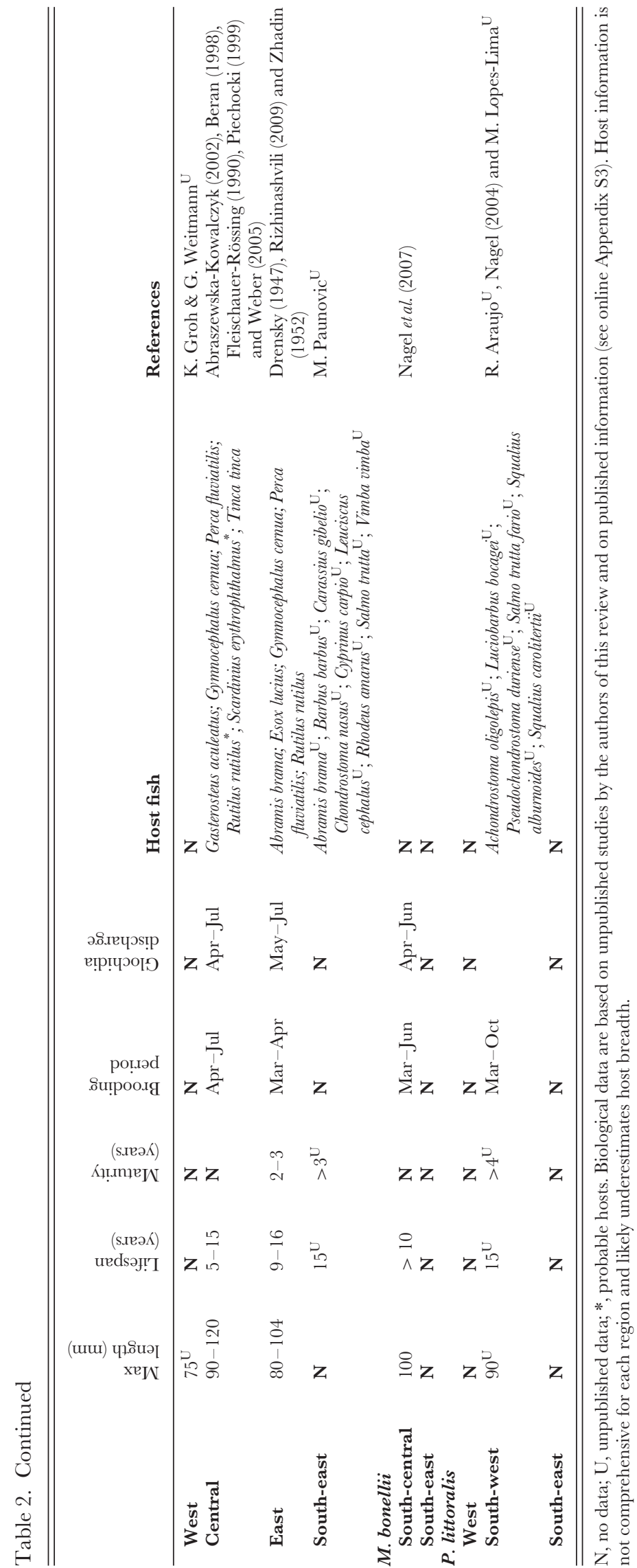



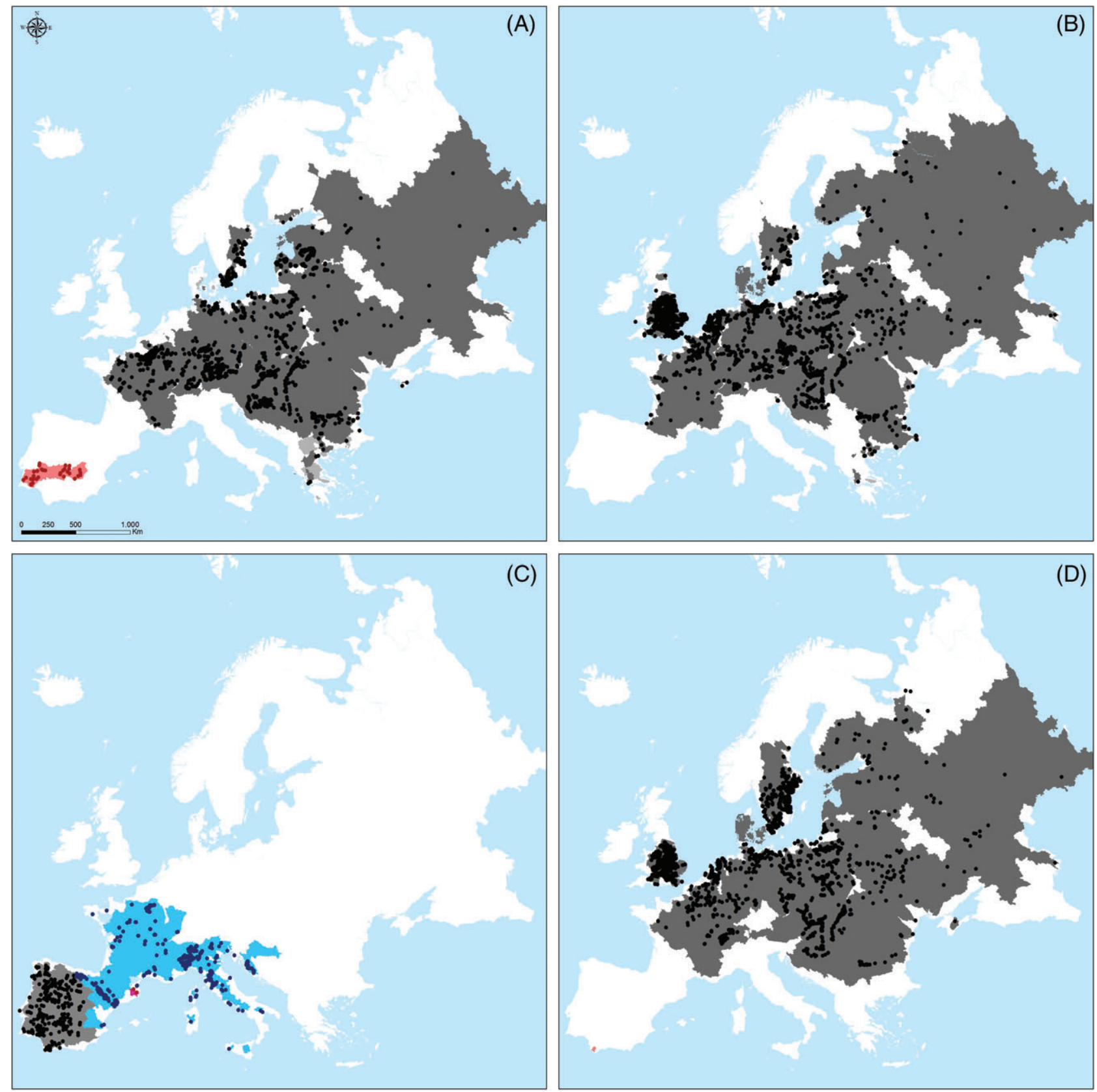

Fig. 5. Distribution of Unionini in Europe. Light shades correspond to historical distribution in hydrographical river basins (prior to 1992), dark shades correspond to present distribution in hydrographical river basins (after 1992) and dots represent present known populations (after 1992). (A) Distribution of Unio crassus (grey) and U. tumidiformis (red); (B) distribution of $U$. pictorum; (C) distribution of $U$. mancus $+U$. cf. elongatulus (blue), of $U$. delphinus (grey) and $U$. ravoisieri (red); (D) distribution of $U$. tumidus (grey) and $U$. gibbus (red). Distribution data are based on recent surveys performed by the authors of this review and published distributions (see online Appendix S2).

but females may switch to hermaphroditism at low population densities (Bauer, 1987). However, some high-density populations can comprise 100\% hermaphrodites (Grande, Araujo \& Ramos, 2001). Seventy per cent of the M. auricularia in the Canal Imperial, Ebro River basin, Spain, were hermaphroditic and 30\% were females (Grande, Araujo \& Ramos, 2001). The D-shaped, unhooked glochidia are small (maximum lengths $45-70 \mu \mathrm{m}$ for $M$. margaritifera and 127-144 $\mu \mathrm{m}$ for M. auricularia) (Araujo \& Ramos, 1998) and are broadcast into the water column. Margaritiferid larvae grow on the host fish to an up to 10-fold size increase until metamorphosis is complete. M. margaritifera uses exclusively salmonid hosts (mainly S. salar and S. trutta) in Europe (Young, 1991; Geist, Porkka \& Kuehn, 2006; Österling \& Larsen, 


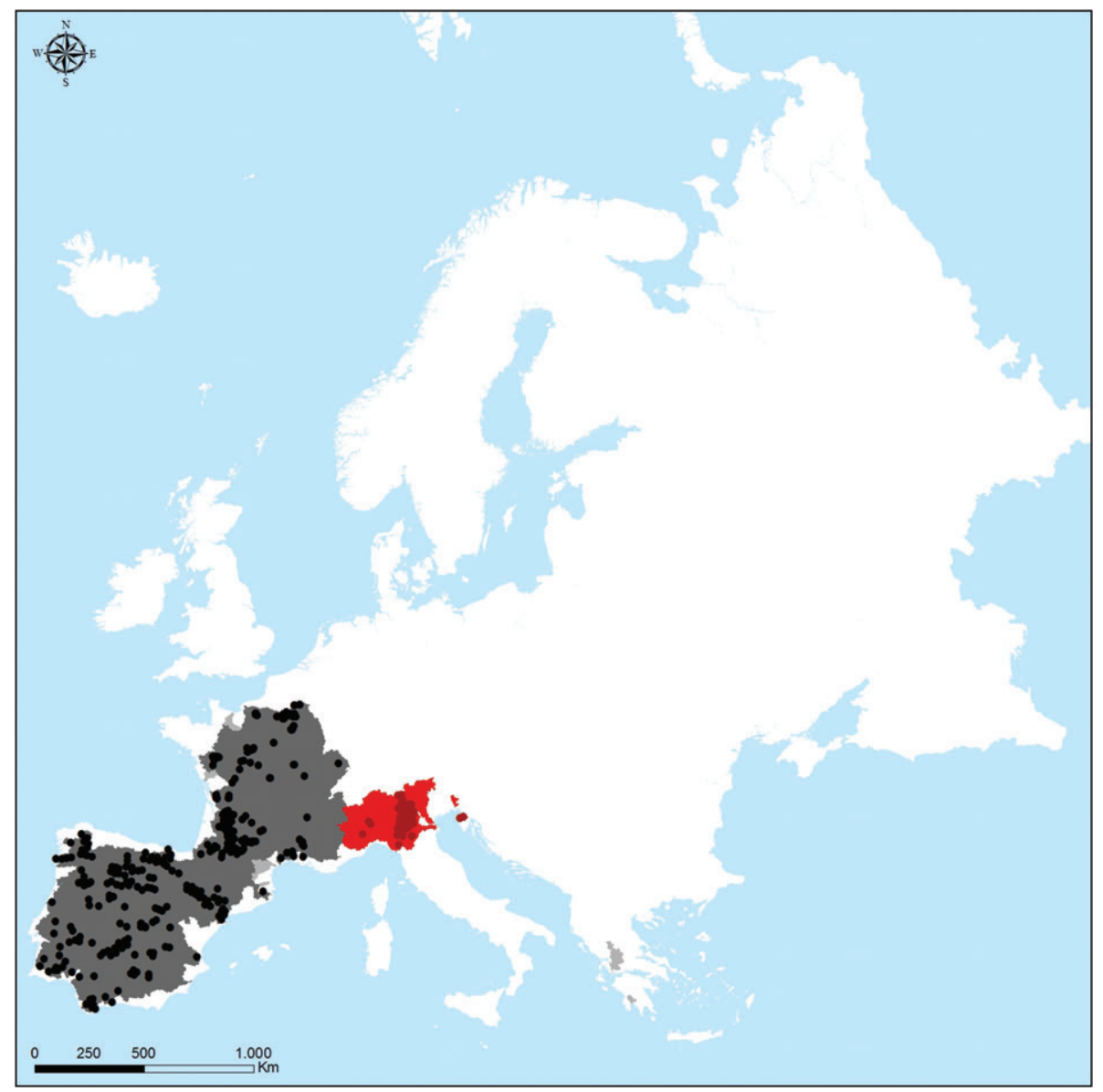

Fig. 6. Distribution of Gonideinae in Europe. Light shades correspond to historical distribution in hydrographical river basins (prior to 1992), dark shades correspond to present distribution in hydrographical river basins (after 1992) and dots represent present known populations (after 1992). Distribution of $P$. littoralis (grey), M. bonellii (red). Distribution data are based on recent surveys performed by the authors of this review and published distributions (see online Appendix S2).

2013), while $M$. auricularia uses European sturgeon (Acipenser sturio) and other Acipenseridae, Eastern mosquitofish (Gambusia holbrooki), and freshwater blenny (Salariafluviatilis) (Table 2).

\section{(b) Unionidae}

(i) Anodontini. European Anodontini typically live for less than 30 years and are sexually mature at $1-4$ years (Table 2). Both Anodonta species favour hermaphroditism in lentic habitats and gonochorism in lotic habitats (Hinzmann etal., 2013). P. complanata is either completely or predominantly dioecious (McIvor \& Aldridge, 2007). Both Anodonta species and $P$. complanata are long-term brooders (bradytictic), keeping the larvae over winter and releasing them from late winter/early spring through the summer. The marsupium is located solely in the outer gill demibranchs (ectobranchy) (Graf \& Cummings, 2007; Hinzmann etal., 2013). The glochidia of Anodontini are triangular, hooked and large (335-409 $\mu \mathrm{m}$; Aldridge \& Horne, 1998; Wächtler, Dreher-Mansur \& Richter, 2001). Both Anodonta species and $P$. complanata are host generalists, metamorphosing on fish from a wide range of families (Table 2). Anodontines release glochidia in mucous webs (Wood, 1974; Haag \& Warren, 1997) and the release of glochidia by $A$. anatina can be stimulated by the presence of the fish host (Jokela \& Palokangas, 1993).

(ii) Unionini. European unionines generally mature between 2 and 4 years of age and live less than 30 years, but longer lifespans have been recorded for countries at higher latitudes (Table 2). With the exception of some populations of $U$. gibbus, which brood glochidia in four gill demibranchs (Araujo et al., 2009b), the Unio species are generally dioecious, ectobranchs, and short-term brooders, having the capacity to generate multiple broods each year generally in the spring and summer months (Aldridge, 1999; Bauer, 2001; Araujo et al., 2009a). However, the reproductive cycles of many Unio species are poorly known. The larvae of Unio species are triangular, hooked (with the exception of $U$. gibbus which are unhooked) and intermediate in size (200-232 $\mu \mathrm{m}$; Wächtler etal., 2001). U. crassus exhibits an unusual host-infestation strategy in which females move to the shoreline and spurt water containing glochidia a short distance into the air; the resulting surface disturbance attracts host fishes (Vicentini, 2005). Glochidia are released in mucous webs by $U$. pictorum 


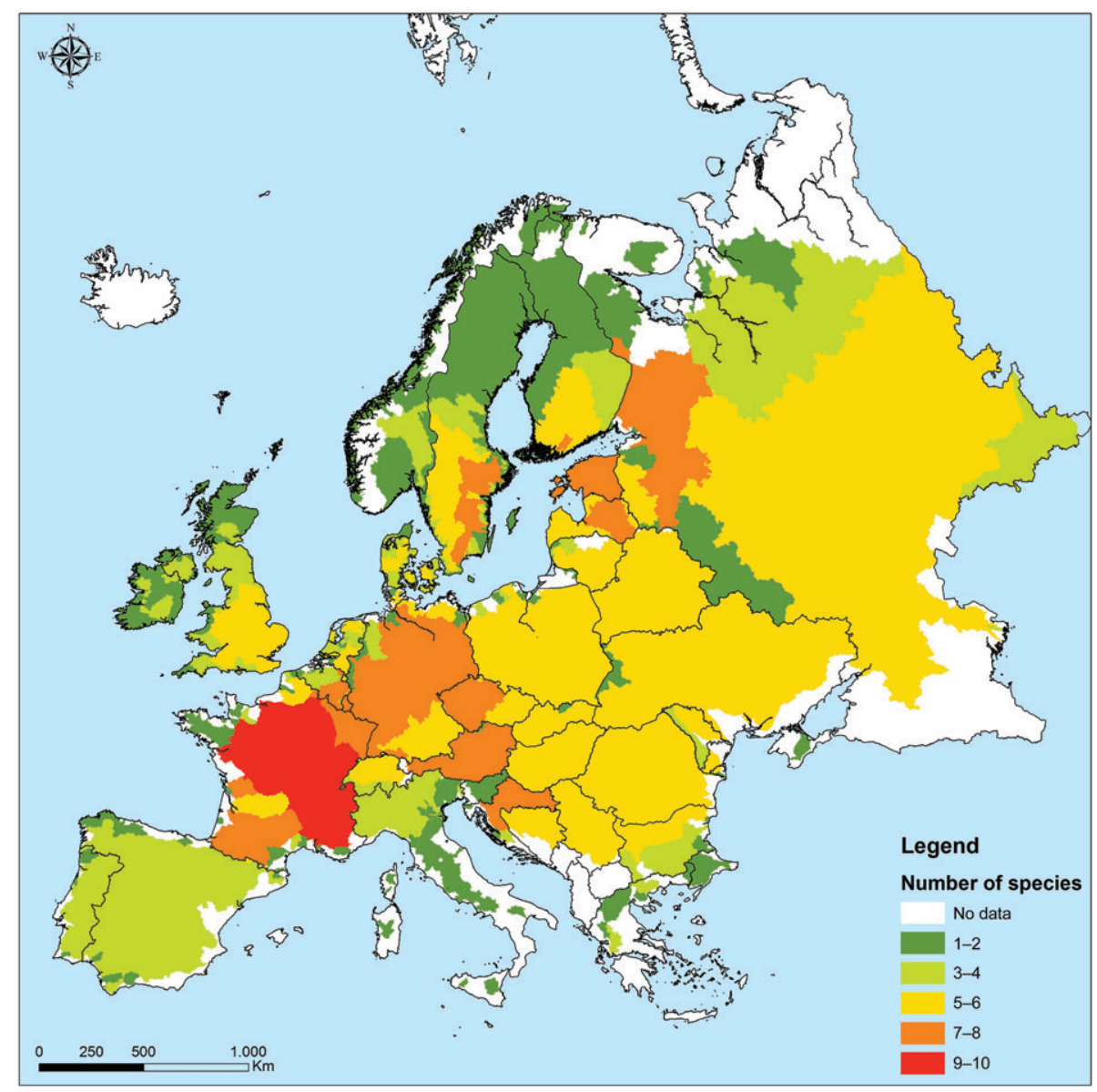

Fig. 7. Species richness of European freshwater mussel species in hydrographical river basins.

(Aldridge \& McIvor, 2003). Many Unio species (including $U$. crassus, $U$. pictorum and $U$. tumidus) release conglutinates (packets of larvae). In North America, such conglutinates may mimic food items that serve to attract host fishes (Haag \& Warren, 2003), but conglutinate release by European mussels likely reflects a response to stress (e.g. hypoxia) because conglutinates are always composed of immature larvae or eggs (e.g. Aldridge \& McIvor, 2003; Gascho Landis et al., 2012). U. pictorum and $U$. tumidus are able to use a wide range of host fishes (Table 2), while $U$. tumidiformis is a host specialist using only Iberian Squalius species (Reis \& Araujo, 2009; Reis, Collares-Pereira \& Araujo, 2014).

(iii) Gonideinae. The two Gonideinae genera are relatively poorly studied, but have been observed to live for $>10$ years. They brood larvae in both inner and outer demibranchs (tetrabranchy), are dioecious and probably short-term brooders (Nagel, 2004; Nagel et al., 2007). The glochidia of both genera are elliptical and unhooked but larger in $P$. littoralis $(\sim 200 \mu \mathrm{m})$ than in $M$. bonellii $(132-154 \mu \mathrm{m})$ (Araujo, Bragado \& Ramos, 2000; Nagel et al., 2007). The infestation strategy is unknown for P. littoralis. $M$. bonellii releases glochidia in worm-like conglutinates, unlike the conglutinates of Unio, those of $M$. bonellii are composed mostly of mature glochidia and appear to attract fish hosts (Nagel etal., 2007). P. littoralis uses a wide range of native fishes, while the hosts for $M$. bonellii remain unknown (Table 2).

\section{(2) Ecology and habitat requirements}

The forces that determine distributions of Unionida species can be best described by: (i) biogeographic history; (ii) host fish distribution; and (iii) local environment including biotic and abiotic factors (Vaughn \& Taylor, 2000). First, in Europe, several biogeographic barriers exist which may explain the distribution of freshwater mussels. For example, the presence of the Alps and the Pyrenees can explain the isolation of several freshwater mussel species in the Italian and Iberian Peninsulas. Large-scale range expansions of freshwater mussels may be also the result of glacial and interglacial periods and river captures (Froufe et al., 2014). Second, mussel distributions are determined to a large extent by the distribution of their host fishes. Species such as $M$. auricularia, that specialize on host fishes with constrained habitat requirements, typically have more restricted distributions than generalist mussel species such as many of the unionines and anodontines (Table 2). Third, at the local scale, habitat characteristics such as current velocity or water and sediment quality and biotic interactions 
such as competition, predation, parasitism and facilitation are usually considered key aspects determining Unionida species composition, density and distribution (for a review, see Strayer, 2008).

Habitat preferences are quite distinct in both European Margaritiferidae species (Table 3; see online Appendix S4). M. margaritifera is a habitat specialist found mostly in cool upland streams with bedrock, cobble, and gravel substratum, moderate flow velocities, low nutrient concentrations and low carbonate content, with salmonid hosts being present (Geist, 2010). By contrast, the few remaining $M$. auricularia populations all occur in large rivers, and even in a canal, with warm temperatures, high conductivity and carbonate content, and outside typical habitat for salmonids (Araujo et al., 2009a).

Similar diversity in habitat use is also seen in the Unionidae. While $P$. complanata generally prefers flowing rivers and streams, A. cygnea is typically associated with canals, eutrophic lakes and ponds where its thin shell allows it to float at the sediment-water interface (Killeen, Aldridge \& Oliver, 2004). A. anatina has a relatively high plasticity and tolerance to different abiotic conditions and can thus be found from fast-flowing streams to lentic habitats (Zieritz \& Aldridge, 2011). Such diversity of habitat requirements is also observed in Unio. For example, U. crassus is typically found in streams with low shear stress (Zajac \& Zajac, 2011) often with high amounts of fine sediments and organic matter (Denic et al., 2014). U. tumidiformis, is able to survive and aggregate in pools subject to high summer temperatures (up to $35^{\circ} \mathrm{C}$ ), in temporary Mediterranean rivers (Reis \& Araujo, 2009). All of the species from the pictorum lineage and $U$. tumidus have similar habitat requirements and generally occur in slow-flowing large rivers or lentic habitats with dominance of fine substrate. Ecophenotypes of $U$. pictorum have been described, with distinctly different growth forms occurring in lentic and lotic sections of the same river system (Zieritz et al., 2010). The two Gonideinae species are generally present in lotic habitats but can be occasionally found in spring-fed lakes (Araujo et al., 2009a; Albrecht et al., 2011).

\section{GONSERVATION}

\section{(1) Conservation status}

Using the last IUCN Red List assessment, of the 16 European species recognized in the present work, 12 are on the Threatened or Near Threatened categories where three are Critically Endangered, two are Endangered, two are Vulnerable, and five are Near Threatened (synonymising $U$. mancus with $U$. cf. elongatulus). One species (U. ravoisieri) was still not assessed and the remaining three species are assessed as Least Concern (Table 4 and also see online Appendix S5).

\section{(a) Margaritiferidae}

Both margaritiferids were classified as Critically Endangered in the 2011 IUCN European assessment on non-marine molluscs (Cuttelod et al., 2011).
M. margaritifera has been exploited in Europe since pre-Roman times for its pearls and for this reason many populations have been managed and protected by local authorities. Therefore, with the exception of the Iberian populations, where most populations have been located only recently (Reis, 2003; Morales etal., 2004; Varandas etal., 2013; Lois etal., 2014), in most countries the historical distribution and extent of recent decline are well known (Young etal., 2001; Geist, 2010). European M. margaritifera populations have decreased dramatically since the beginning of the 20th century (up to 90\%) and this trend is ongoing (Geist, 2010). The species is most likely extinct in Belarus, Denmark, Lithuania, and Poland, and more than 95\% of the remaining populations in southern and central Europe are highly fragmented and functionally extinct due to the lack of recent recruitment (Young et al., 2001; Geist, 2010). Many M. margaritifera populations have also disappeared in northern latitudes (e.g. Finland and Russia; Oulasvirta, 2011; Makhrov et al., 2014). The largest European populations with recent recruitment are found in the least densely populated areas of northern Europe (e.g. Kola peninsula, Scotland; Geist, 2010). Poor recruitment in $M$. margaritifera has been attributed to the long juvenile phase ( $>5$ years) where animals bury within coarse, well-oxygenated substrates; such habitat has been lost as a result of anthropogenic eutrophication and siltation (Geist \& Auerswald, 2007). Since 1992 this species has been listed in annexes II and V of the European Commission (EG) Habitats Directive and has attracted the main portion of European Community funds devoted to freshwater bivalve conservation (Gum, Lange \& Geist, 2011). The decline of $M$. auricularia in both abundance and extent of occurrence is estimated to be over 90\% (Prié, 2010), and it is now almost extinct, surviving only in Spain and France. The few remaining populations are aging with only the Charente, Vienne (Loire), Luy (Adour) and Dronne (Garonne) Rivers still showing signs of recruitment within the past 15 years. The probable primary host (A. sturio) is extinct in the Ebro basin and has almost disappeared from France (Gessner et al., 2010).

\section{(b) Unionidae}

(i) Anodontini. Neither Anodonta species is considered to be threatened in Europe because population numbers and distribution are large (Hinzmann etal., 2013). Like many anodontines in other parts of the world (Strayer, 2008; Haag, 2012), European Anodonta seem to be rather adaptable and have persisted in or colonized many highly altered or degraded habitats. However, while A. anatina is currently listed by the IUCN as Least Concern (Lopes-Lima, 2014), some populations of $A$. cygnea are declining and the species was assessed as Near Threatened in 2011 (Killeen \& Aldridge, 2011). Recent studies have identified regional genetic differences for both $A$. anatina (Froufe etal., 2014) and A. cygnea (Geist, Geismar \& Kuehn, 2010a), and such studies are helping to identify important conservation or management units. For example, one of the $A$. anatina lineages, which includes individuals from Italy and the Ebro 


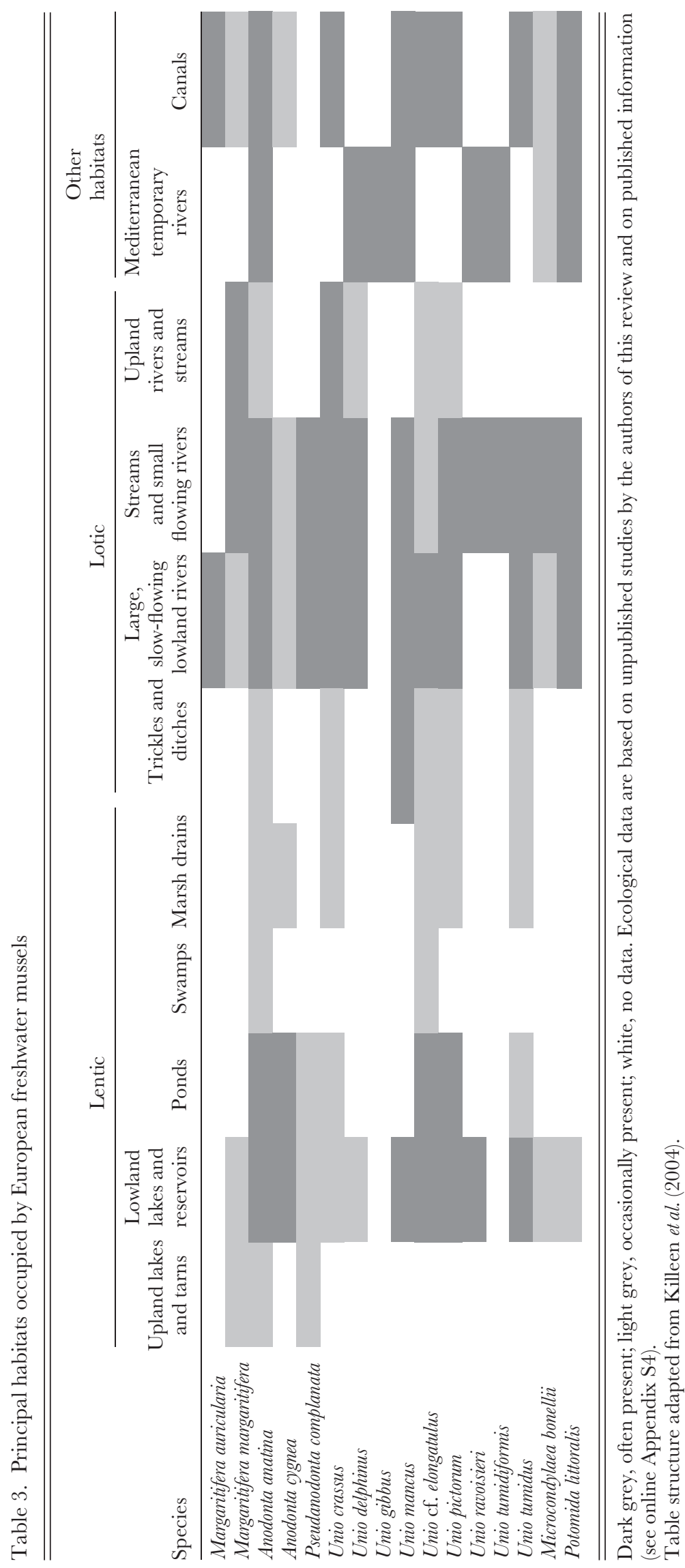




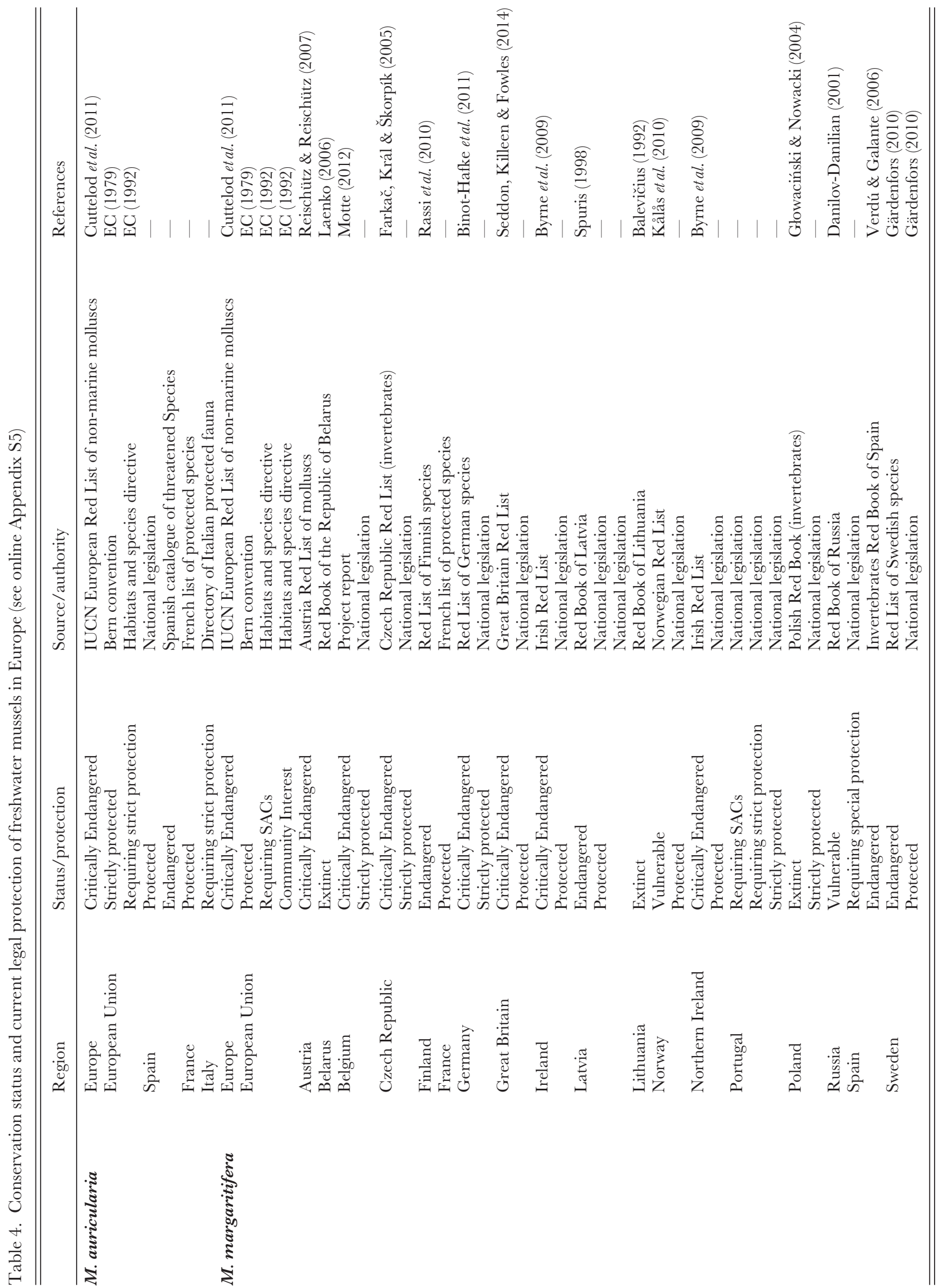




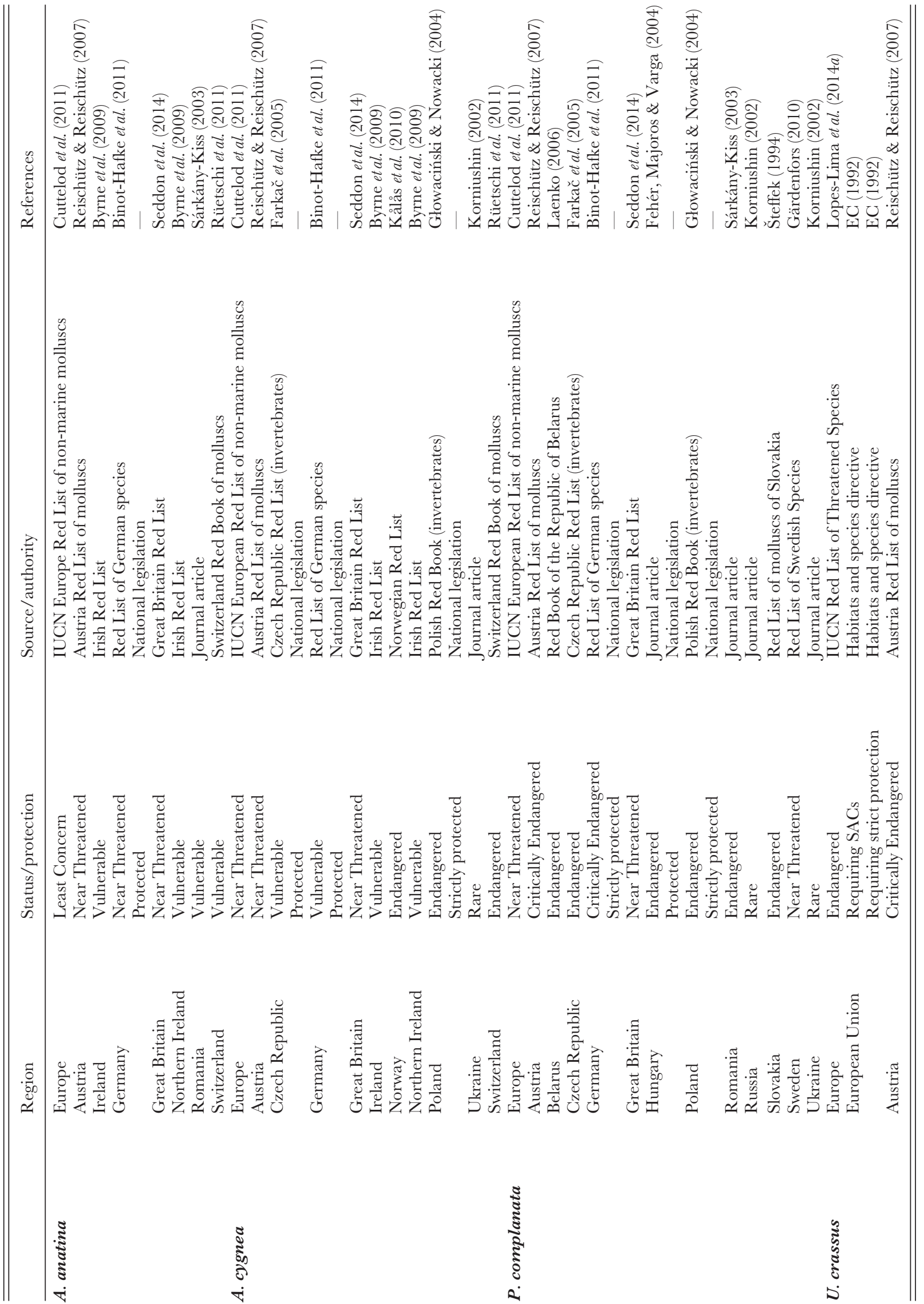




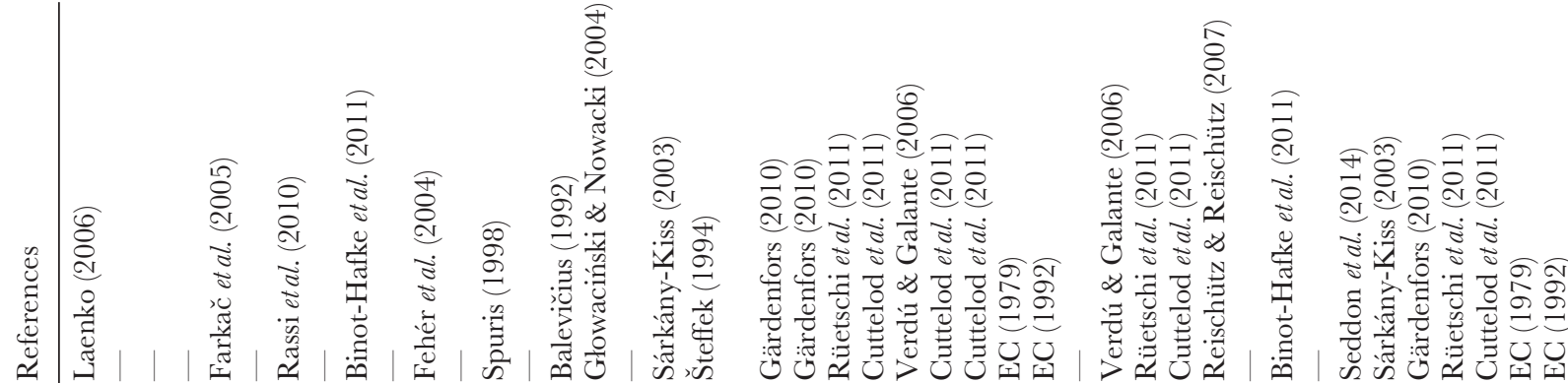

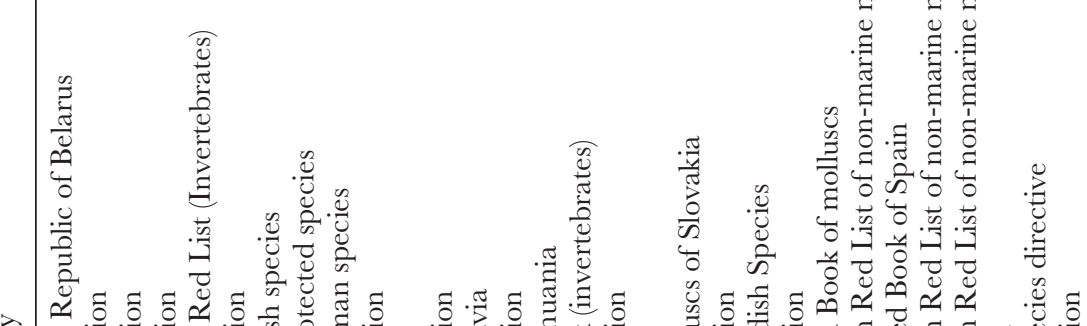

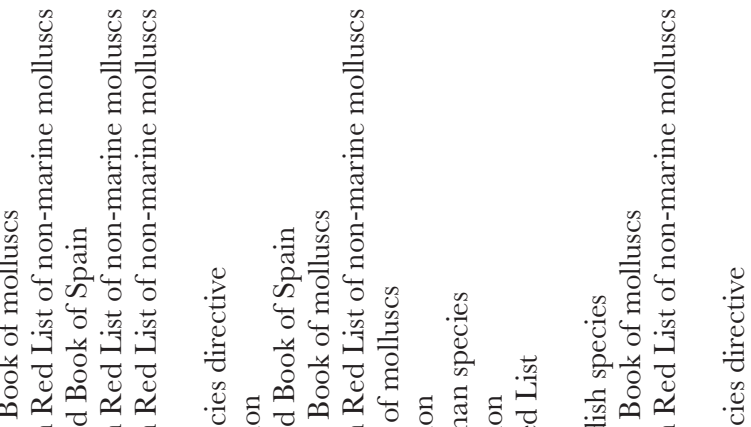
.

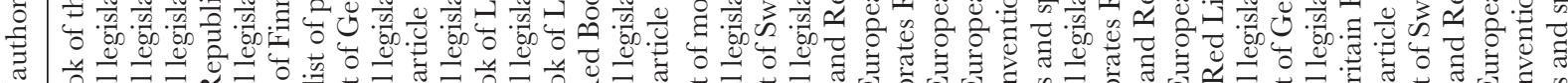

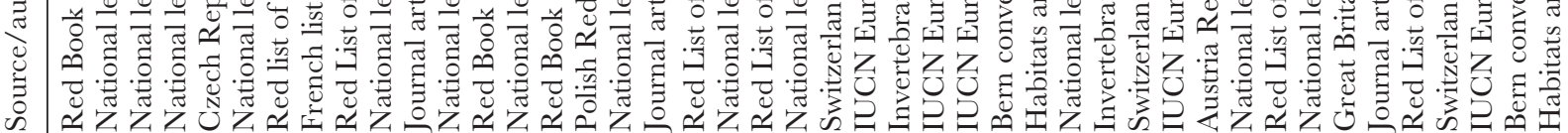

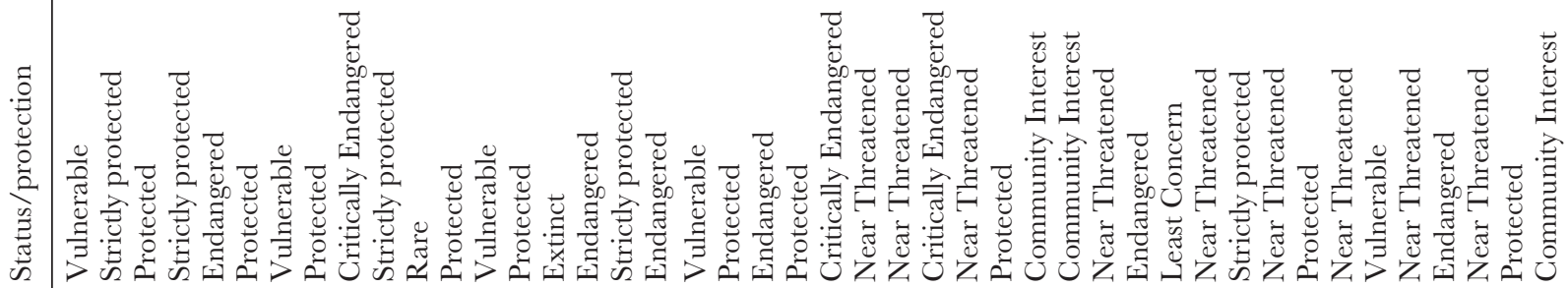

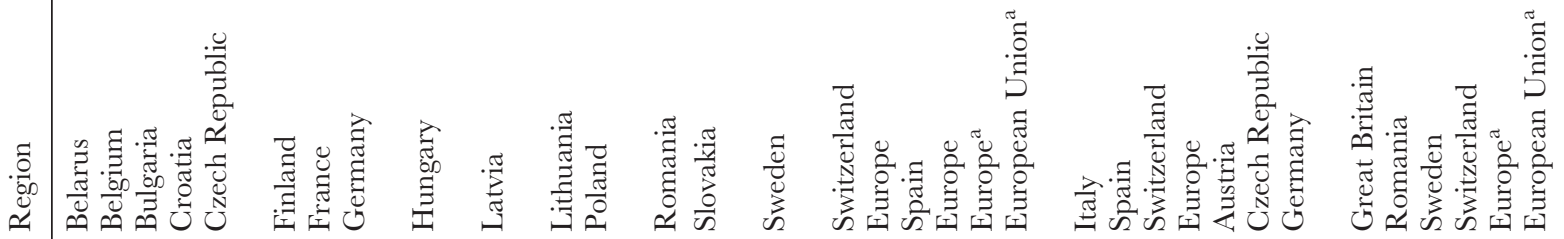

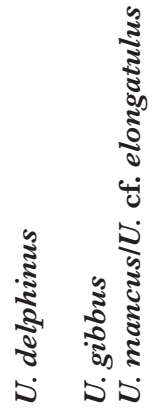




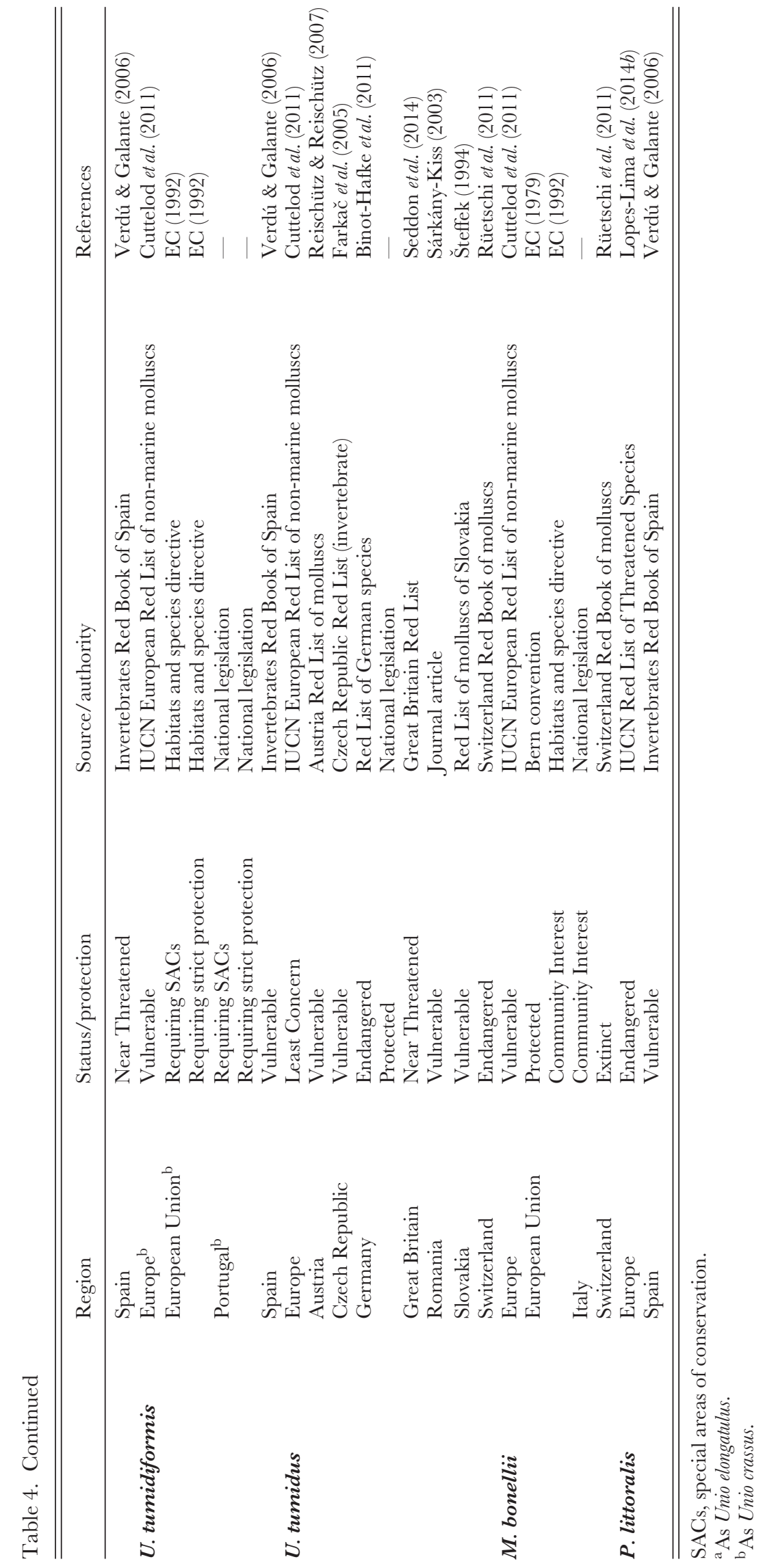


basin, in Spain (Froufe et al., 2014), is especially restricted in distribution and is decreasing rapidly (Araujo et al., 2009a). $P$. complanata is rare across its entire distribution and there is evidence for widespread declines $(>50 \%$ over the last few decades) in populations from the UK, central Europe, and Ukraine (Tudorancea, 1972; Aldridge, 2004; McIvor \& Aldridge, 2007). This species is listed by the IUCN as Near Threatened (Van Damme, 2011a) and is already protected in several countries (Table 4).

(ii) Unionini. $U$. crassus, once considered the most abundant unionid in Europe, declined dramatically (up to $50 \%$ both in the number of individuals and populations) in western and central Europe during the second half of the 20th century (Bauer, Hochwald \& Silkenat, 1991; Lopes-Lima, Kebapçi \& Van Damme, 2014a). This species is protected and considered critically endangered in several European countries (Table 4). In 2014 it was assessed as Endangered by the IUCN (Lopes-Lima et al., 2014a) and is listed in annexes II and IV of the EG Habitats Directive. Populations seem to be stable only in the Baltic and eastern European countries (Lopes-Lima et al., 2014a). However, in recent surveys several recruiting populations were newly discovered in Germany (Stoeckl, Taeubert \& Geist, 2015), indicating that gaps in known distribution are even present in the most intensely monitored species. In contrast to $M$. margaritifera, where increased loads of fine sediment appear to be problematic, this factor is unlikely to be responsible for the observed declines in $U$. crassus (Denic etal., 2014). Instead, direct threats such as predation by invasive muskrat (Ondatra zibethicus) (Zahner-Meike \& Hanson, 2001), dredging and insufficient host fish populations appear to be the main causes of decline, at least in central Europe (Taeubert, Gum \& Geist, 2012a; Taeubert et al., 2012b; Stoeckl et al., 2015).

$U$. tumidiformis has a restricted distribution in small rivers of southern Iberia, a region severely affected by water extraction (Benejam etal., 2010). The populations are very scattered and sparse, with recent declines in number of populations of $30-35 \%$ (Araujo, 2011e). The species is considered Vulnerable by the IUCN over its entire distribution (Araujo, $2011 e$ ), and is protected (as U. crassus) in Portugal and Spain under annexes II and IV of the EC Habitats Directive.

$U$. pictorum is one of the most widespread unionid species in Europe where it has been assessed as Least Concern by the IUCN (Van Damme, 2011b). Although no comprehensive surveys and monitoring programmes have been carried out across its entire distribution, due to recent declines it is of emerging concern in some countries (e.g. Austria, Germany, Great Britain, and Sweden) where it is listed as Near Threatened.

$U$. mancus has undergone a strong decline in both number of populations and individuals in its western distribution (Araujo etal., 2009a; Prié etal., 2012). It was listed as Near Threatened in Europe in 2011 by the IUCN (Araujo, 2011d), although more recent data suggest each of three French subspecies could be considered as Endangered (Prié etal., 2012). There are no data regarding the conservation status of $U$. mancus in south-eastern Europe. U. mancus is protected in Spain under the Habitats and Species Directive Annex V under the name $U$. elongatulus.

Unio cf. elongatulus can be locally abundant, but the number of populations is declining. Surveys from 2012 to 2014 (N. Riccardi, unpublished data) confirmed only 59 of the 97 populations reported by Bodon et al. (2005). It has not been assessed by the IUCN since it has only recently been recognized.

The status of $U$. delphinus has not been determined rigorously, but a recent assessment estimated a 20-30\% population loss over the last 50 years (Araujo, 2011b). The species was considered as Near Threatened by the IUCN (Araujo, 2011b).

$U$. ravoisieri has never been evaluated formally but the species should be considered as Endangered or even Critically Endangered in Europe, due to a very low abundance and a European distribution restricted to a single small Mediterranean basin (River Ser) and a single small lake (Lake Banyolas) in Catalonia, Spain. Additionally, the Lake Banyolas fish fauna has changed dramatically in recent years with the introduction of 12 non-native species (including largemouth bass, Micropterus salmoides, pumpkinseed sunfish, Lepomis gibbosus and roach, Rutilus rutilus), which may reduce the availability of suitable hosts (García-Berthou \& Moreno-Amich, 2008). Unio ravoisieri is protected in Spain under the Habitats and Species Directive Annex $\mathrm{V}$ under the name $U$. elongatulus.

$U$. tumidus is considered to be abundant and widespread in its entire distribution, having been assessed as Least Concern in Europe by the IUCN (Van Damme, 2011c). However, should be considered Vulnerable in France where $>70 \%$ reduction in its historical distribution has been estimated (Prié et al., 2014).

$U$. gibbus is probably the most endangered freshwater mussel species in Europe. It is found only in the Barbate basin in southern Spain (Araujo etal., 2009b) and only two live individuals have been found since 2007. It is listed as Critically Endangered by the IUCN (Araujo, 2011c).

(iii) Gonideinae. The conservation status of $P$. littoralis was recently assessed by the IUCN as Endangered (Lopes-Lima, Prié \& Seddon, 2014b). P. littoralis has suffered a strong decline in both the number of populations and individuals and almost $75 \%$ of its recorded populations in the Iberian Peninsula have disappeared or are likely to disappear within the next 10 years (Araujo, $2011 a$ ). In France, although historically known from all main drainages, where empty shells can still be found, living individuals are becoming rare and many populations are declining with a suggested distribution contraction of around 75\% (Prié et al., 2014). It is probably extirpated from the Seine River basin and from several small Mediterranean basins.

M. bonellii is listed on Annex $\mathrm{V}$ of the EG Habitats and Species Directive as a protected species. It has been assessed as Vulnerable in Europe by the IUCN (Albrecht et al., 2011). In Italy the number of populations is very small and it is presumed extinct in Switzerland (Rüetschi etal., 2011). The best-known recruiting populations occur in the Po 
River tributaries Marcova, Rotaldo, Stura (N. Riccardi, unpublished data) and one Isonzo tributary Versa (Nagel etal., 2007).

\section{(2) Major threats}

Globally, known major threats to freshwater biodiversity include loss, fragmentation and degradation of habitat, overexploitation, pollution, introduction of non-native invasive species, and climate change (Dudgeon etal., 2006; Geist, 2011). European freshwater mussels are vulnerable to all these threats. Other currently unknown factors may also play a role.

\section{(a) Habitat loss, fragmentation and degradation}

Most streams and rivers in Europe are highly altered physically and damage to mussel habitats continues to be a concern (Geist, 2014). Dams and channelization alter the physical characteristics of aquatic ecosystems and can disrupt natural meta-population structure by preventing gene flow (e.g. Geist \& Kuehn, 2005). The resulting fragmentation is also a threat to long-term population persistence because it eliminates the possibility of recolonization after a severe disturbance (e.g. drought, toxic spill) due to the interruption of fish host migration from adjacent non-disturbed areas (Haag, 2012). Even small dams can be a major barrier to the dispersal of fish carrying glochidia (Watters, 1996). This situation may be more acute in freshwater mussels such as M. margaritifera that are dependent on mobile or migratory host fishes, but less important in mussel species such as $A$. anatina that use less-mobile hosts (Douda etal., 2013). In Europe, about 7000 large (>15 m high) dams exist (Limburg \& Waldman, 2009). There is a high pressure for establishing new dams for hydropower in central Europe (e.g. Germany and Poland) and for irrigation in the Iberian Peninsula and the Balkans. Dams typically favour lentic or generalist taxa such as $A$. anatina and reduce or eliminate lotic species such as M. margaritifera (Burlakova et al., 2011; Mueller, Pander \& Geist, 2011).

Dams also negatively affect mussel habitat through changes in sediments, river flow, and temperature (Mueller et al., 2011). Increased sedimentation upstream of dams and decreases in sediment porosity are particularly harmful to rheophilic mussel species such as $M$. margaritifera, directly by increasing juvenile mortality (Geist \& Auerswald, 2007; Österling, Arvidsson \& Greenberg, 2010), and indirectly by reducing hatching rates of salmonid hosts (Sternecker \& Geist, 2010; Sternecker, Cowley \& Geist, 2013). Other riverine freshwater mussel species such as $U$. crassus appear to be much more tolerant of fine sediments (Zajac \& Zajac, 2011; Denic etal., 2014). Water releases from dams often result in both abnormally high and low flows (Vaughn \& Taylor, 1999). High water velocities can displace adults and juveniles and may impair recruitment. By contrast, extended periods of low flow below impoundments can result in mussel mortality due to stranding and low dissolved oxygen levels. Changes to thermal regimes as a result of dams can have strong effects on fish communities, on the reproductive ability of freshwater mussels (Heinricher \& Layzer, 1999), as well as the timing and successful development of mussel larvae on their fish hosts (Taeubert, El-Nobi \& Geist, 2014). Dredging of river beds and weed removal using mechanical excavators can directly remove large numbers of mussels and may increase the risk of smothering through the temporary suspension of fine sediments (Aldridge, 2000; Cosgrove \& Hastie, 2001). Interestingly, old and stable side channels and ditches often offer refuge to mussels from highly managed main channels. For example, in Spain $P$. littoralis predominates in rice ditches and side channels in the Valencia region, and M. auricularia persists in the Channel of Tauste in the Ebro River basin (Gómez \& Araujo, 2008).

\section{(b) Overexploitation}

In Europe, pearl fishing has historically been a major threat to many central and northern European populations of $M$. margaritifera (Young et al., 2001; Makhrov et al., 2014). Strict laws now prohibit these activities but poaching continues in some countries (e.g. Scotland and Russia) (Hastie, 2006; Bolotov et al., 2012). Until the 1990s, a craft industry existed in the Region of Aragon, Spain, for the use of M. auricularia nacre to make buttons and decorate jack-knife hilts (Álvarez, 1998). Occasional reports also describe the direct consumption of some mussel species by humans and domestic animals in Europe (e.g. Tudorancea, 1972). Although overexploitation of freshwater mussels may be responsible for local declines, it cannot account for declines at the European scale.

\section{(c) Pollution and eutrophication}

There is a wide variety of contaminants that can potentially affect freshwater mussels, despite the small number of studies that explicitly address this issue in European species. In general, free glochidia larvae are more vulnerable to pollutants than glochidia attached to fish, or juvenile mussels and adults (Bringolf etal., 2007; Taskinen etal., 2011). The effects of point-source contamination can be highly detrimental to freshwater mussels, as was the case with a heavy metal spill in River Tisza in 2000, which probably affected freshwater mussel populations (Fleit \& Lakatos, 2003). However, diffuse sources appear much more important than point sources of pollution in Europe. For example, increased loads of road de-icing salt, which can flush into watercourses along large parts of their length, have been shown to alter filtration behaviour in adult $A$. anatina (Hartmann etal., in press), and to reduce the attachment success of $A$. anatina glochidia to their host fishes, with peak concentrations of salt application typically coinciding with the timing of glochidial release (Beggel \& Geist, 2015). Diffuse pollutants such as road salt are difficult to manage and no legally prescribed environmental quality standards for salt have been established in Europe (Cañedo-Argüelles et al., 2013). Both point-source and diffuse pollution typically differ in terms of scale with the latter being a greater and region-wide problem. 
Heavy metals such as copper and cadmium (typically from industrial pollution) can affect the calcification and formation of mussel shells, with toxicity increasing at low $\mathrm{pH}$ values (e.g. Pynnönen, 1995). Environmental pollutants such as the organochlorine insecticide DDT, its metabolite DDE, and cadmium have been linked to mussel specimens with thinner and less calcified shells from declining $M$. margaritifera populations (Frank \& Gerstmann, 2007). The direct and indirect effects of acidification from airborne pollution have been particularly problematic in poorly buffered areas of Fennoscandia, Sweden, with liming activities used to mitigate the effects of poor shell deposition in $M$. margaritifera populations (Degerman et al., 2009).

The introduction of nutrients and fine sediment from agricultural run-off is considered a major threat for European freshwater mussels. Nitrogen and phosphorous concentrations are elevated and increasing in most European regions (Galloway et al., 2008; Douda, 2010; Grizzetti et al., 2011). Eutrophication and fine-sediment deposition are particularly detrimental to highly specialized species such as M. margaritifera (Bauer, 1988; Geist \& Auerswald, 2007; Denic \& Geist, 2015), whereas habitat generalist species such as Anodonta sp. can, to a certain degree, tolerate or even benefit from eutrophication (Patzner \& Müller, 2001). For rheophilic species, buried juvenile mussels are especially affected by eutrophication and siltation because they require well oxygenated substrates. In $M$. margaritifera, juveniles depend on a well-sorted stream bed with high exchange rates with the water collumn for the first 5 years of life. Eutrophication-driven siltation and colmation of stream beds has been linked with recruitment failure in this species (Geist \& Auerswald, 2007). Low redox potential in the stream bed can trigger the reduction of nitrate to toxic nitrite and ultimately ammonium, which is in a $\mathrm{pH}$-dependent equilibrium with toxic forms of ammonia. Eutrophication-associated reduction in dissolved oxygen can also induce hypoxic stress in Unionida mussels, promoting the release of eggs and immature glochidia, which in turn can lead to reduced reproductive success (Aldridge \& McIvor, 2003).

Pharmaceutical compounds, dioxins and brominated flame retardants can have acute and chronic effects on the reproduction and survival of freshwater mussels (Augspurger et al., 2007; Connon, Geist \& Werner, 2012). The number of studies specifically addressing the effects of these compounds on European freshwater mussels is currently too small for a sound assessment of their importance (Strayer \& Malcom, 2012).

\section{(d) Loss offish hosts}

In recent decades European ecosystems have been subject to the disappearance of native freshwater fish species, especially in areas with high freshwater fish endemism (e.g., Iberian Peninsula; Hermoso etal., 2011). Host limitation is most likely to occur for mussel species with restricted host fish spectra, such as $M$. margaritifera and $M$. auricularia. Observed declines in salmonids and sturgeon (e.g. Gessner etal.,
2010; Geist, 2015) have put those mussel species high on the agenda for conservation. On the other hand, in $M$. margaritifera habitats, a high richness, density and biomass of fish can also be indicative of eutrophication and habitat degradation (Geist et al., 2006). Since its fish host has a much shorter substrate-dependent phase it can benefit from slight eutrophication in the form of an increased population density and biomass. In that study, non-recruiting populations of $M$. margaritifera had significantly higher density and biomass of brown trout $(S$. trutta) compared to recruiting ones, which indicates that even slight eutrophication can result in adverse effects on pearl mussel recruitment. Furthermore, declines in host-generalist European Unionida mussels, such as $U$. crassus, can be linked to declines of their host fish species in certain areas (Douda, Horký \& Bílý, 2012; Taeubert etal., 2012a,b; Stoeckl et al., 2015).

\section{(e) Invasive species}

Hundreds of non-native species are now established in European freshwater ecosystems (DAISIE, 2009). The invasive bivalve species in European freshwater ecosystems include Corbicula fluminea (Müller 1774), Corbicula fluminalis (Müller 1774), Dreissena rostriformis bugensis (Andrusov 1897), Dreissena polymorpha (Pallas 1771) and Sinanodonta woodiana (Lea 1834), and all these bivalves may be especially detrimental to native Unionida freshwater mussels.

Corbicula is native to Asia and was first found in Europe in the early 1980s. The species is now present from Portugal in the west to Romania in the east, and the UK and Ireland in the north (Crespo et al., 2015). C. fluminea has been shown to reduce the growth and survival of sympatric $P$. complanata in $\mathrm{UK}$ rivers, and this may be attributable to the organic enrichment of sediments through biodeposition of faeces and pseudofaeces.

D. $r$. bugensis and D. polymorpha are native to the Ponto-Caspian region. D. polymorpha established broadly through Europe in the 18th and 19th centuries and is now present in north-west Russia, much of central and western Europe, and Scandinavia (reviewed in Aldridge, Elliott \& Moggridge, 2004). D. r. bugensis is a more recent invader into western Europe and is spreading rapidly (e.g. Aldridge, Ho \& Froufe, 2014). Direct competition for food is thought to be one of the major mechanisms for the decline of Unionida mussels in North America (Strayer \& Malcom, 2007). In addition, dreissenid bivalves possess byssus threads which allow them to attach to the valves of native mussels. Fouling from $D$. polymorpha can make it more difficult for Unionida mussels to burrow and move through sediments, the increased weight can result in the underlying Unionida mussel becoming buried in soft sediments, while higher drag can increase the likelihood of dislodgment by water motion. In some cases, $D$. polymorpha can prevent valve movement of the underlying Unionida mussel, thus hampering filter feeding, respiration, and reproduction. Dreissenid fouling of Unionida mussels can lead to a depletion of biomass and total energy stores, and can result in localized extirpations of European Unionida mussels 
(Sousa, Pilotto \& Aldridge, 2011; Bódis, Tóth \& Sousa, 2014a).

S. woodiana is a unionid native to south-eastern Asia and has colonized several European countries (from Spain in the south-west to Ukraine in the east and Sweden in the north; reviewed in Lajtner \& Crnčan, 2011). Dense populations of $S$. woodiana may compete with native Unionida mussels for food, increase resistance to glochidia in potential host fish, and serve as vectors of introduction of new parasites and diseases (see Sousa et al., 2014). However, many of these impacts remain speculative.

The introduction of non-native macrophytes can also impair the survival of freshwater bivalves. In the Iberian Peninsula, A. cygnea populations are located in three small lakes in the north of Portugal, all of which are heavily invaded by the water hyacinth (Eichhornia crassipes). When this invasive plant undergoes mass mortality at the end of the summer, this results in the accumulation of dead organic matter and consequent reduction in redox potential and decrease in oxygen leading to high mortalities in A. cygnea (M. Lopes-Lima \& R. Sousa, unpublished data). Other invasive plants such as Myriophyllum aquaticum, Elodea canadensis, Elodea nuttallii and Egeria densa may have similar effects on European freshwater mussels.

Recent studies showed that invasive fish species have a lower suitability as a host of $A$. anatina than native fish species (Douda etal., 2013). Reproductive success of freshwater mussels could be reduced if there is an increased likelihood of glochidia attaching to a less-suitable host. Introduction of bivalve predators such as crayfish, fishes, and mammals may also be responsible for declines in native freshwater mussels (Zahner-Meike \& Hanson, 2001; Aldridge, 2004). In the case of $U$. crassus, the presence of the muskrat was responsible for significant local density declines (up to 80\% in 1 year for a Swiss population) in a very short period of time in Luxembourg, Germany and Switzerland (Vicentini \& Pfändler, 2001).

\section{(f) Water abstraction and climate change}

Growing demands for water by agricultural, industrial and recreational activities, especially in southern European countries (e.g. Portugal, Spain, Italy and Greece), has caused significant negative impacts on Mediterranean freshwater ecosystems including decline and loss of endemic freshwater biodiversity (Benejam etal., 2010). These impacts may be exacerbated by predicted climatic change towards an increased inter-annual variability in precipitation and consequent effects in river flows (Millán, Estrela \& Miró, 2005). In addition, extreme climatic events are predicted to become more frequent and intense in the future (Diez etal., 2012). Droughts and floods have already contributed to massive die-offs of European freshwater mussels (e.g. Hastie et al., 2001; Mouthon \& Daufresne, 2006; Sousa et al., 2012; Bódis, Tóth \& Sousa, 2014b). Even small temperature changes can strongly affect metamorphosis success and larval development in freshwater mussels (Taeubert, Gum \& Geist, 2013; Taeubert et al., 2014), with knock-on consequences to recruitment success (Sousa etal., 2013, 2015). Particularly affected may be freshwater mussel populations at the edges of their distribution, such as those in the south of Europe, where intolerance to increased temperatures combined with low dispersal capacity may impair their survival in these regions (Santos et al., 2015).

In many instances freshwater mussels are likely to be exposed to multiple stressors, such as pollution, invasive species and climate change at the same time, which can place species at even greater risk. For example, a recent study modelled the projected distribution across Europe of the Near Threatened unionid $P$. complanata and the invasive, D. polymorpha under 2050 future climatic scenarios (Gallardo \& Aldridge, 2013). These authors found that while $D$. polymorpha may benefit strongly from climate changes (increase of $15-20 \%$ in distribution), P. complanata would experience considerable loss $(14-36 \%$ shrinkage in distribution). Furthermore, the overlap of the two species was predicted to increase by up to $24 \%$, meaning that $P$. complanata would be subject to increased risk of fouling with fewer refugia.

\section{(g) Other threats}

In addition to the above identified threats, many aquatic ecosystems have experienced massive mussel declines in the last decades, even though the habitat appears intact with healthy populations of fish, insects, gastropods, and other biota. Similar observations were also made in North America (e.g. Haag, 2012; Haag \& Williams, 2014). Consequently, further research into currently unknown stressors, and the interaction of multiple stressors warrants further attention.

\section{(3) Conservation and management measures}

Conservation of European freshwater mussels is essential to maintain the ecosystem functions and services they provide. Unfortunately, the European Natura 2000 network has a primary focus on terrestrial biodiversity, failing sufficiently to cover freshwater species in general (Hermoso et al., 2015), and Unionida mussels in particular.

Effective conservation plans should be aimed at multiple scales, striving to identify distinct populations or evolutionarily significant units (ESUs), populations threatened at the local scale, biodiversity hotspots and to promote river management in response to species' needs. An evidence-based structured conservation approach that includes defining conservation objectives, as well as an evaluation of conservation action and adaptive management, could greatly improve conservation success, but is still rarely applied in Europe (Geist, 2015). As a second step after the definition of objectives, information on current distribution and population size of each species is required to define conservation priorities. These conservation priorities must be assessed species-specifically and at the regional population level because even in co-occurring mussel species different factors may limit their recruitment. For example, whereas deficiencies in central European M. margaritifera recruitment 
can mostly be explained by excess amounts of fine sediment (Geist \& Auerswald, 2007), U. crassus populations seem to be more tolerant to these conditions (Denic etal., 2014) but host fishes are often limiting (Douda etal., 2012; Taeubert etal., 2012a,b; Stoeckl etal., 2015). Ideally, sound conservation projects should incorporate ecological and genetic information (Geist \& Kuehn, 2005; Geist, 2010). The genetically most valuable populations can be identified based on their respective contribution to the variation in the gene pool across its entire species distribution (Geist \& Kuehn, 2008). Isolated lineages representing unique or rare genotypes should be afforded due importance.

Based on ecological criteria, prioritization should include protection of the healthiest populations in the most intact habitats. Identifying sites which harbour multiple mussel species may often serve as a focus for conservation efforts at the national or regional scale. For example, the River Mustionjoki (Svartå) in southern Finland harbours all of the seven mussel species that occur in that country and the River Wye hosts all six of the UK's mussel species. Conservation priority should be also given to regions that harbour species with a very restricted distribution (e.g. $U$. gibbus in the River Barbate basin) that, due to their localized distribution, are especially vulnerable to extinction. In some cases, willingness of local communities and stakeholders to support restoration should also be taken into account when prioritizing sites for conservation (Geist, 2015).

Where populations are facing extinction, conservation can take two principal directions: the restoration of aquatic habitats including their catchments, or artificial culture and propagation. Ideally, the two approaches should be combined. Restoration of aquatic habitats, especially of substratum properties, can be extremely time-consuming, expensive, and conflicting management goals may arise (Geist, 2011; Pander \& Geist, 2013). Artificial propagation is likely to produce a much quicker output, particularly in species where the methodology is established. In Europe, most propagation has focussed on $M$. margaritifera (Gum et al., 2011). However, cultured mussels need to be released in suitable habitats and therefore this method can only be effective if there are suitable candidate areas for release or if it is realistic that habitats can be restored.

To date, there have been 28 projects within the LIFE program (the European Union's funding instrument for the environment) devoted to the restoration of freshwater mussel habitats, with a total funding of 64 million Euros. However, the funding distribution has been uneven with the majority being directed to the conservation of $M$. margaritifera (18) and $U$. crassus (5), with three additional projects targeting both species. Such Europe-wide and national-scale conservation projects have had different levels of success. Whilst the production of juvenile mussels in larger quantities has become feasible (reviewed in Gum et al., 2011), the number of successful habitat restorations remains extremely limited. One project on the Lutter River in northern Germany restored recruitment of $M$. margaritifera after reduction of fine-sediment inputs and restoration of the entire catchment area (Geist, 2010). Another project at the Biała River (Poland) removed four dams, which increased fish migration and allowed for successful recolonization of $U$. crassus (Zajac et al., 2013). These two examples illustrate that restoration of freshwater mussel habitats is possible, but it also shows that substantial effort and time are needed to achieve success. While successful examples of freshwater mussel conservation schemes are likely to be recorded in peer-review journals and reports, unsuccessful examples also carry important information and convey important lessons. Resources such as www.conservationevidence.com provide an effective portal for capture of such information.

Since the successful recruitment of freshwater mussels is highly dependent on the availability of suitable host fish, the integration of fisheries management in rivers with known mussel populations should also be part of conservation plans. For freshwater mussel populations that are known or suspected to be limited by host availability, e.g. U. crassus (Douda et al., 2012; Taeubert et al., 2012a; Stoeckl et al., 2015), the abundance of key host fish species should be actively supported, even if they are considered to be of low economic value (Taeubert et al., 2012a,b).

Despite ongoing international discussions on freshwater mussel research, current conservation approaches are typically directed towards solving local problems. Whilst conservation actions necessarily need to work at the regional scale, it would be highly beneficial if strategic planning for conservation followed a more standardized approach. This requires better international collaboration in the development of tools for the mapping of mussel distributions, and quantifying density and recruitment status. Conservation prioritization should include socio-economic arguments concerning the value of aquatic biodiversity (see also Geist, 2010, 2011). By way of example, experts from across Europe have recently collaborated on the development of a European GEN (Comité Européen de Normalisation) standard that can serve as a guideline and aid the conservation management of $M$. margaritifera. Similar actions for all other 15 species could be very helpful. The declining rates of European freshwater mussels and the increasing threats to them, along with the targets of NATURA 2000 and the European Water Framework Directive, provide strong arguments for immediate action. This multi-author review by freshwater mussel specialists from all over Europe indicates that there is a critical mass of experts that needs to be more strongly engaged in future conservation planning.

\section{GONGLUSIONS}

(1) Currently, 16 species are recognized in European Unionida: two species of Margaritiferidae and 14 species of Unionidae. Most basins in northern, central, and eastern Europe have a relatively homogeneous species composition containing mostly up to six different species. Southern Europe has an overall lower species richness, but several 
species with spatially restricted geographical distributions are found in this area. Information on freshwater mussels in Europe is unevenly distributed with considerable differences in data quality and quantity among countries and species.

(2) Freshwater mussels are an important component of aquatic ecosystems. Changes in their diversity and population structure are being driven by habitat loss and fragmentation, overexploitation, pollution, loss of host fishes, introduction of non-native species, water abstraction and climate change. Resultant declines may have important repercussions in ecosystem functions and services. While we have considerable understanding of the fundamental ecological requirements of some species, such as $M$. margaritifera, we know very little about most recognized European species especially $U$. gibbus and $M$. bonellii. In addition, great variability in knowledge exists across different European regions; some central European countries have been well studied but almost no data are available for south-eastern European countries such as Albania, Macedonia, and Greece. Therefore, more studies should be conducted in order to fill these gaps, which may enhance our ability to apply effective management measures.

(3) As a first step, a systematic understanding of the limiting factors in the life cycle of every species is crucial, since even closely related species may have different ecological requirements. For species for which suitability of host fishes is unclear or unknown (e.g. U. gibbus and M. bonellii) or for which detailed information concerning habitat preferences is scarce (e.g. U. tumidus and P. complanata), these factors must be investigated. In addition to the required knowledge of life history and habitat requirements of mussels and their fish hosts, a continuous update on taxonomy (including genetics) and distribution data considering ESUs and conservation units is required. Ideally, such data should be generated in a harmonized, cross-European approach instead of the focus on national conservation management that is currently practiced. This could ultimately lead to priority setting among and within species on a European scale, which would make conservation more effective.

(4) Despite dramatic declines and extinction risk existing for several European freshwater mussel species, there are reasons to be optimistic. For example, water quality has improved greatly in recent decades, allowing mussels to return to several rivers, ponds and lakes. Media coverage has brought attention to the conservation status of this faunal group and so more people recognize these animals as an important conservation target. Finally, the number of European scientists studying freshwater mussels has increased greatly in recent decades. As a result, more information about ecological aspects and new ways to conserve these species are emerging. Efforts to conserve native freshwater mussel diversity on a larger scale would benefit from the formulation of a European action plan, or strategy, to consolidate the energies of academics, natural resource agencies, and the general public.

\section{AGKNOWLEDGEMENTS}

The authors appreciate the extensive work of Wendell Haag and two anonymous reviewers that improved the quality of the manuscript; Arthur Bogan and David Strayer for their assistance and careful thoughts; Marco Paulo Magalhães for help with the GIS maps; Imre Potyó for the photo of Pseudanodonta complanata; the people who took part in the Belarusian data collection especially I. A. Rudakovskiy and V. M. Samoilenko (Belarusian State University), and G. M. Tischikov and I. G. Tischikov (Republican GidroMeteoCenter of Belarus); Marco Bodon and Simone Cianfanelli for valuable information on Italian populations; all the people who provided us with the data included in the French INPN database; Zdravko Hubenov, Dimitar Kozuharov, Lyubomir Kenderov and Ivan Botev for the help with the Bulgarian data collection; and I.N. Bolotov, O.V. Aksenova, I.V. Vikhrev, A. A. Makhrov, P. E. Aspholm for help with the collection and analysis of the Russian data.

Financial support was provided by: The Portuguese Foundation for Science and Technology (FCT) and COMPETE funds, project 'CONBI' (Contract: PTDC/ AAC-AMB/117688/2010) and project 'ECO-IAS' (Contract: PTDC/AAC-AMB/116685/2010); The Bavarian State Ministry of the Environment and Consumer Protection through the Bavarian Mussel Coordination Office; The Federal Government of Upper Austria (Department of Nature Conservation), by the Environmental Councilor (Manfred Haimbuchner) and by the European Union; Ministry of Natural Resources and Environmental Protection Republic of Belarus, Belarusian Committee of Ecology grant 288/73 from the Belarussian State University grant 444/50 and from the Ministry of Education and Science Republic of Belarus grant 657/65; The Ministry of Science, Education and Sports of the Republic of Croatia (119-1193080-1231), Hrvatske vode and State Institute for Nature Protection; The Czech Science Foundation (13-05872S) and ESF/MŠMT (CZ.1.07/2.3.00/30.0040); Biotope Consultancy, grants from Muséum National d'Histoire Naturelle à Paris, ATM Barcode and Agence Nationale de la Recherche '6eme extinction'; Polish Ministry of Science and Higher Education grant NCN No. NN304328836; The Russian Foundation for Basic Research, RFBR (grant no. 15-04-05638, 14-04-98801_a) and The Ural Branch of RAS (no.15-12-5-3), President of the Russian Federation (grant no. MD-6465.2014.5).

\section{REFERENCES}

\footnotetext{
References marked with asterisk have been cited within the supporting information. Abraszewska-Kowalczyk, A. (2002). Unionid bivalves of the Pilica river catchment area. Folia Malacologica 10, 99-173.

Albrecht, C., Bodon, M., Cianfanelli, S., Giusti, F. \& Manganelli, G. (2011). Microcondylaea bonellii. IUCN red list of threatened species. Version 2015.2. Available at http://www.iucnredlist.org/ Accessed 30.06.2015.

Aldridge, D. C. (1999). The morphology, growth and reproduction of Unionidae (Bivalvia) in a Fenland waterway. Fournal of Molluscan Studies 65, 47-60.
} 
Aldidide, D. C. (2000). The impacts of dredging and weed cutting on a population of freshwater mussels (Bivalvia: Unionidae). Biological Conservation 95, 247-257.

Aldridge, D. C. (2004). Conservation of freshwater unionid mussels in Britain. Fournal of Conchology, Special Publication 3, 81-90.

Aldridge, D. G., Elliott, P. \& Moggridge, G. D. (2004). The recent and rapid spread of the zebra mussel (Dreissena polymorpha) in Great Britain. Biological Conservation 119, 253-261.

Aldridge, D. C., FAyle, T. M. \& JAckson, N. (2007). Freshwater mussel abundance predicts biodiversity in UK lowland rivers. Aquatic Conservation: Marine and Freshwater Ecosystems 17, 554-564.

Aldridge, D. C., Ho, S. \& Froufe, E. (2014). The Ponto-Caspian quagga mussel, Dreissena rostriformis bugensis (Andrusov, 1897), invades Great Britain. Aquatic Invasions 9, 529-535.

Aldridge, D. C. \& Horne, D. C. (1998). Fossil glochidia (Bivalvia, Unionidae): identification and value in palaeoenvironmental reconstructions. Fournal of Micropalaeontology 17, 179-182.

Aldridge, D. G. \& McIvor, A. L. (2003). Gill evacuation and release of glochidia by Unio pictorum and Unio tumidus (Bivalvia: Unionidae) under thermal and hypoxic stress. Fournal of Molluscan Studies 69, 55-59.

Álvarez, R. M. (1998). The Margaritifera auricularia mother-of-pearl industry and environmental management in Aragon. Temas de Antropología Aragonesa 8, 113-212 (in Spanish).

Araujo, R. (2011a). Potomida littoralis (Cuvier, 1798). In Atlas and Red Book of Threatened Invertebrates Spain (eds J. R. Verdú, C. Numa and E. Galante), pp. 1036-1051. Dirección General de Medio Natural y Política Forestal, Ministerio de Medio Ambiente, Medio Rural y Marino, Madrid (in Spanish).

Araujo, R. (2011b). Unio delphinus. IUCN red list of threatened species. Version 2015.2. Available at http://www.iucnredlist.org/. Accessed 30.06.2015.

Araujo, R. (2011 c). Unio gibbus. IUCN red list of threatened species. Version 2015.2. Available at http://www.iucnredlist.org/ Accessed 30.06.2015.

Araujo, R. $(2011 d)$. Unio mancus. IUCN red list of threatened species. Version 2015.2. Available at http://www.iucnredlist.org/. Accessed 30.06.2015.

Araujo, R. (2011e). Unio tumidiformis. IUCN red list of threatened species. Version 2015.2. Available at http://www.iucnredlist.org/. Accessed 30.06.2015.

Araujo, R., Bragado, D. \& Ramos, M. A. (2000). Occurrence of glochidia of the endangered Margaritifera auricularia (Spengler, 1793) and other mussel species (Bivalvia: Unionida) in drift and on fishes in an ancient channel of the Ebro River. Archiv für Hydrobiologie 148, 147-160.

Araujo, R., Bragado, D. \& Ramos, M. A. (2001). Identification of the river blenny, Salaria fluviatilis, as a host to the glochidia of Margaritifera auricularia. Fournal of Molluscan Studies 67, 128-129.

Araujo, R., Cámara, N. \& Ramos, M. A. (2002). Glochidium metamorphosis in the endangered freshwater mussel Margaritifera auricularia (Spengler, 1793): a histological and scanning electron microscopy study. Fournal of Morphology 254, 259-265.

Araujo, R. \& DE Jong, Y. (2015). Fauna Europaea: Mollusca-Bivalvia. Biodiversity Data fournal 3, E5211.

Araujo, R., Gómez, I. \& Machordom, A. (2005). The identity and biology of Unio mancus Lamarck, 1819 (=U. elongatulus) (Bivalvia: Unionidae) in the Iberian Peninsula. Foumal of Molluscan Studies 71, 25-31.

Araujo, R., Quirós, M. \& Ramos, M. A. (2003). Laboratory propagation and culturing of juveniles of the endangered freshwater mussel Margaritifera auricularia (Spengler, 1793). Fournal of Conchology 38, 53-60.

Araujo, R. \& Ramos, M. A. (1998). Description of the glochidium of Margaritifera auricularia (Spengler, 1793) (Bivalvia, Unionidae). Philosophical Transactions of the Royal Society of London, Series B: Biological Sciences 353, 1553-1559.

Araujo, R. \& Ramos, M. A. (2000). Status and conservation of the relict giant European freshwater pearl mussel Margaritifera auricularia (Spengler, 1793). Biological Conservation 96, 233-239.

Araujo, R. \& Ramos, M. A. (2001). Action Plan for Margaritifera margaritifera. In Convention on the Conservation of European Wildlife and Natural Habitats (Bern Convention), Nature and Environment 117, pp. 29-66. Council of Europe Publishing, Strasbourg.

Araujo, R., Reis, J., Machordom, A., Toledo, C., Madeira, M. J., Gómez, I., Velasco, J. C., Morales, J., Barea, J. M., Ondina, P. \& Ayala, I. (2009a). The naiads of the Iberian Peninsula. Iberus 27, 7-72 (in Spanish).

Araujo, R., Toledo, C. \& Machordom, A. (2009b). Redescription of Unio gibbus Spengler, 1793, a west palaearctic freshwater mussel with hookless glochidia. Malacologia 51, 131-141.

Araujo, R., Toledo, C., Van Damme, D., Ghamizi, M. \& Machordom, A. (2009c). Margaritifera marocana (Pallary, 1918): a valid species inhabiting Moroccan rivers. Fournal of Molluscan Studies 75, 95-101.

Augspurger, T., Dwyer, F. J., Ingersoll, G. G. \& Kane, G. M. (2007). Advances and opportunities in assessing contaminant sensitivity of freshwater mussel (Unionidae) early life stages. Environmental Toxicology and Chemistry 26, 2025-2028.

Balevičius, A. (1992). Red Data Book of Lithuania. Ministry of Environment, Vilnius (in Lithuanian).

BAuer, G. (1987). Reproductive strategy of the freshwater pearl mussel Margaritifera margaritifera. Fournal of Animal Ecology 56, 691-704.
BAuer, G. (1988). Threats to the freshwater pearl mussel Margaritifera margaritifera L. in central Europe. Biological Conservation 45, 239-253.

Bauer, G. (1991). Plasticity in life history traits of the freshwater pearl mussel. Consequences for the danger of extinction and for conservation measures. In Species Conservation: A Population-Biology Approach (eds A. Seitz and V. Loeschcke), pp. 103-120. Birkhäuser-Verlag, Basel.

BAUER, G. (2001). Life-history variation on different taxonomic levels of naiads In Ecology and Evolution of the Freshwater Mussels Unionoida (eds G. BAUER and K WÄCHTLER), pp. 83-91. Springer-Verlag, Heidelberg.

Bauer, G., Hochwald, S. \& Silkenat, W. (1991). Spatial distribution of freshwater mussels: the role of host fish and metabolic rate. Freshwater Biology 26, 377-386.

BEGGEL, S. \& GEIST, J. (2015). Acute effects of salinity exposure on glochidia viability and host infection of the freshwater mussel Anodonta anatina (Linnaeus, 1758). Science of the Total Environment 502, 659-665.

Benejam, L., Angermeier, P. L., Munne, A. \& García-Berthou, E. (2010). Assessing effects of water abstraction on fish assemblages in Mediterranean streams. Freshwater Biology 55, 628-642.

Beran, L. (1998). Aquatic molluscs of the Czech Republic. In Methodology of the Czech Union for Nature Conservation No.17. ZO ČSOP, Vlašim (in Czech).

Bespalaya, Y. V., Bolotov, I. N \& Makhrov, A. A. (2007). State of the population of the European pearl mussel Margaritifera margaritifera (L.) (Mollusca, Margaritiferidae) at the northeastern boundary of its range (Solza river, White Sea Basin). Russian fournal of Ecology 38, 204-211.

Bespalaya, Y. V., Bolotov, I. N., Makhrov, A. A. \& Vikhrev, I. V. (2012). Historical geography of pearl fishing in rivers of the southern White Sea region (Arkhangelsk Oblast). Regional Research of Russia 2, 172-181.

Binot-Hafke, M., Balzer, S., Becker, N., Gruttke, H., Haupt, H., Hofbauer, N., Ludwig, G., Matzke-Hajek, G. \& Strauch, M. (2011). Red List of Endangered Aanimals, Plants and Fungi Germany, Invertebrates (Part 1) (Volume 3). Bundesamt für Naturschutz, Bonn-Bad Godesberg (in German).

Bódis, E., Tóth, B. \& Sousa, R. (2014a). Impact of Dreissena fouling on the physiological condition of native and invasive bivalves: interspecific and temporal variations. Biological Invasions 16, 1373-1386.

Bódis, E., Tóth, B. \& Sousa, R. (2014b). Massive mortality of invasive bivalves as a potential resource subsidy for the adjacent terrestrial food web. Hydrobiologia 735, $253-262$.

Bogan, A. E. \& RoE, K. J. (2008). Freshwater bivalve (Unioniformes) diversity, systematics, and evolution: status and future directions. Fournal of the North American Benthological Society 27, 349-369.

Bolotov, I. N., Bespalaya, Y. V., Makhrov, A. A., Aspholm, P. E., Aksenoy, A. S., Gofarov, M. Y., Dvoryankin, G. A., Usacheva, O. V., Vikhrev, I V., Sokolova, S. E., Pashinin, A. A. \& Davydov, A. N. (2012). Influence of historical exploitation and recovery of biological resources on contemporary status of Margaritifera margaritifera L. and Salmo salar L. populations in Northwestern Russia. Biology Bulletin Reviewes 2, 460-478.

Bolotov, I. N., Makhrov, A. A., Bespalaya, Y. V., Vikhrev, I. V., Aksenova, O. V., Aspholm, P. E., Gofarov, M. Y., Ostrovskit, A. N., Popov, I. Y. Pal'tser, I. S., Rudzite, M., Rudzitis, M., Voroshilova, I. S. \& Sokolova, S. E. (2013). Results of testing the comparatory method: the curvature of the shell valve frontal section is inappropriate as a systematic character for the freshwater pearl mussel of the genus Margaritifera. Biology Bulletin 40, 221-231.

Bringolf, R. B., Cope, W. G., Eads, C. B., Lazaro, P. R., Barnhart, M. C. \& SHEA, D. (2007). Acute and chronic toxicity of technical-grade pesticides to glochidia and juveniles of freshwater mussels (Unionidae). Environmental Toxicology and Chemistry 26, 2086-2093.

Burlakova, L. E., Karatayev, A. Y., Karatayev, V. A., May, M. E., Bennett, D. L. \& CoOK, M. J. (2011). Endemic species: contribution to community uniqueness, effect of habitat alteration, and conservation priorities. Biological Conservation 144, $155-165$.

Byrne, A., Moorkens, E. A., Anderson, R., Killeen, I. J. \& Regan, E. C. (2009). Ireland Red List No. 2. Non-Marine Molluscs. National Parks and Wildlife Service, Department of the Environment, Heritage and Local Government, Dublin.

Cañedo-Argüelles, M., Kefford, B. J., Piscart, C., Prat, N., Schäfer, R. B. \& Schulz, C. J. (2013). Salinisation of rivers: an urgent ecological issue. Environmental Pollution 173, 157-167.

Castagnolo, L. (1977). Reproductive life cycle of Anodonta cygnea L. and Unio elongatulu. Pfeif. in Po di Tolle. Rivista di Idrobiologia 16, 1-14 (in Italian).

Chesney, H. C. G., Oliver, P. G. \& Davis, G. M. (1993). Margaritifera durrovensis Phillips, 1928: taxonomic status, ecology and conservation. Journal of Conchology 34, 267-299

ClaEs, M. (1987). Studies on the developmental biology of the pond mussel Anodonta cygnea. Master Thesis: Universität Hannover (in German).

Connon, R., Geist, J. \& Werner, I. (2012). Effect-based tools for monitoring and predicting the ecotoxicological effects of chemicals in the aquatic environment Sensors 12, 12741-12771.

Cosgrove, P. J. \& Hastie, L. C. (2001). Conservation of threatened freshwater pearl mussel populations: river management, mussel translocation and conflict resolution. Biological Conservation 99, 183-190. 
Crespo, D., Dolbeth, M., Leston, S., Sousa, R. \& Pardal, M. Â. (2015). Distribution of Corbicula fluminea (Müller, 1774) in the invaded range: a geographic approach with notes on species traits variability. Biological Invasions 17, 2087-2101.

Cuttelod, A., Seddon, M. \& Neubert, E. (2011). European Red List of Non-Marine Molluscs. Publications Office of the European Union.

DAISIE (2009). European invasive alien species gateway. Available at http:// www.europe-aliens.org/. Accessed 30.06.2015.

Danilov-Danilian, V. I. (2001). Red Data Book of the Russian federation: Animals. AST and Astrel Publishers, Moscow.

*Darriba, D., Taboada, G. L., Doallo, R. \& Posada, D. (2012). jModelTest 2: more models, new heuristics and parallel computing. Nature Methods 9, 772.

Degerman, E., Alexanderson, S., Bergengren, J., Henrikson, L., Johansson, B.-E., Larsen, B. M. \& Söderberg, H. (2009). Restoration of Freshwater Pearl Mussel Streams. World Wildlife Fund, Solna.

Denic, M. \& GEIST, J. (2015). Linking stream sediment deposition and aquatic habitat quality in pearl mussel streams: implications for conservation. River Research and Applications 31, 943-952.

Denic, M., Stoeckl, K., Gum, B. \& Geist, J. (2014). Physicochemical assessment of Unio crassus habitat quality in a small upland stream and implications for conservation. Hydrobiologia 735, 111-122.

Denic, M., Taeubert, J.-E. \& Geist, J. (2015). Trophic relationships between the larvae of two freshwater mussels and their fish hosts. Invertebrate Biology 134, $129-135$.

Diez, J. M., D’antonio, C. M., Dukes, J. S., Grosholz, E. D., Olden, J. D., Sorte, G. J. B., Blumenthal, D. M., Bradley, B. A., Early, R., Ibáñez, I., Jones, S. J., Lawler, J. L. \& Miller, L. P. (2012). Will extreme climatic events facilitate biological invasions? Frontiers in Ecology and the Environment 10, 249-257.

DomagaŁa, J. (1998). Histological analysis of gonads of female Anodonta anatina (L.) (Bivalvia: Unionidae) from March till October. Folia Malacologica 6, 1-4.

DoudA, K. (2010). Effects of nitrate nitrogen pollution on Central European unionid bivalves revealed by distributional data and acute toxicity testing. Aquatic Conservation: Marine and Freshwater Ecosystems 20, 189-197.

DoudA, K., HorkÝ, P. \& Bílý, M. (2012). Host limitation of the thick-shelled river mussel: identifying the threats to declining affiliate species. Animal Conservation 15, $536-544$.

Douda, K., Lopes-lima, M., Hinzmann, M., Machado, J., Varandas, S., Teixeira, A. \& Sousa, R. (2013). Biotic homogenization as a threat to native affiliate species: fish introductions dilute freshwater mussel's host resources. Diversity and Distributions 19, 933-942.

Drensky, P. (1947). Synopsis and distribution of freshwater Mollusca in Bulgaria. Annuaire de l'Universite de Sofia, Faculte Physico-Mathematique 43, 33-54 (in Bulgarian).

Dudgeon, D., Arthington, A. H., Gessner, M. O., Kawabata, Z., Knowler, D., Lévêque, G., Naiman, R. J., Prieur-Richard, A. H., Soto, D. \& Stiassny, M. L.J. (2006). Freshwater biodiversity: importance, threats, status, and conservation challenges. Biological Reviewes 81, 163-182.

Dunca, E., Sönerberg, H. \& Norrgrann, O. (2011). Shell growth and age determination in the freshwater pearl mussel Margaritifera margaritifera in Sweden: natural versus limed streams. Ferrantia $64,48-58$.

EC (1979). Convention on the Conservation of European Wildlife and Natural Habitats. 19. IX.1979. Council of Europe, Bern.

EC (1992). Council of Europe Directive 92/43/EEC of 21 May 1992 on the conservation of natural habitats and of wild fauna and flora. Brussels.

Falkner, G., Bank, R. \& Von Proschwitz, T. (2001). Checklist of the non-marine molluscan species-group taxa of the states of Northern, Atlantic and Central Europe (GLECOM Area I). Heldia 4, 1-76.

Farkač, J., KRÁL, D. \& ŠKorpík, M. (2005). Czech Republic Red List (Invertebrates). AOPK C̆R, Prague.

Fehér, Z., Majoros, G. \& VArga, A. (2004). A scoring method for the assessment of rarity and conservation value of the Hungarian freshwater molluscs. Heldia $\mathbf{6}$, $127-140$.

Fleischauer-Rössing, S. (1990). Studies on the autecology of Unio tumidus Philipsson and Unio pictorum Linnaeus (Bivalvia), with special consideration of the early post-parasitic phase. PhD Thesis: Universität Hannover (in German).

Fleit, E. \& Lakatos, G. (2003). Accumulative heavy metal patterns in the sediment and biotic compartments of the Tisza watershed. Toxicology Letters 140-141, 323-332.

Frank, H. \& Gerstmann, S. (2007). Declining populations of freshwater pearl mussels (Margaritifera margaritifera) are burdened with heavy metals and DDT/DDE. Ambio $36,571-574$.

Froufe, E., Sobral, C., Teixeira, A., Sousa, R., Varandas, S., Aldridge, D. C. \& Lopes-Lima, M. (2014). Genetic diversity of the pan-European freshwater mussel Anodonta anatina (Bivalvia: Unionoida) based on CO1: new phylogenetic insights and implications. Aquatic Conservation: Marine and Freshwater Ecosystems 24, $561-574$.

Gallardo, B. \& Aldridge, D. C. (2013). Evaluating the combined threat of climate change and biological invasions on endangered species. Biological Conservation 160, $225-233$.
Galloway, J. N., Townsend, A. R., Erisman, J. W., Bekunda, M., Cai, Z., Freney, J. R., Martinelli, L. A., Seitzinger, S. P. \& Sutton, M. A. (2008). Transformation of the nitrogen cycle: recent trends, questions, and potential solutions. Science 320, 889-892.

García-Berthou, E. \& Moreno-Amich, R. (2008). Fish ecology and conservation in Lake Banyoles (Spain): the neglected problem of exotic species. In Management and Ecology of Lake and Reservoir Fisheries (ed. I. G. Cowx), pp. 223-231. Blackwell Science, Fishing News Books, Oxford.

Gärdenfors, U. (2010). Red List of Swedish Species. Artdatabanken, SLU, Uppsala (in Swedish)

Gascho Landis, A. M., Mosley, T. L., HaAg, W. R. \& Stoeckel, J. A. (2012). Effects of temperature and photoperiod on lure display and glochidial release in a freshwater mussel. Freshwater Science 31, 775-786.

Geist, J. (2010). Strategies for the conservation of endangered freshwater pearl mussels (Margaritifera margaritifera L.): a synthesis of conservation genetics and ecology. Hydrobiologia 644, 69-88.

GEIST, J. (2011). Integrative freshwater ecology and biodiversity conservation. Ecological Indicators 11, 1507-1516.

GEIST, J. (2014). Trends and directions in water quality and habitat management in the context of the European water framework directive. Fisheries 39, 219-220.

GeIst, J. (2015). Seven steps towards improving freshwater conservation. Aquatic Conservation: Marine and Freshwater Ecosystems 25, 447-453.

Geist, J. \& Auerswald, K. (2007). Physicochemical stream bed characteristics and recruitment of the freshwater pearl mussel (Margaritifera margaritifera). Freshwater Biology 52, 2299-2316.

Geist, J., Geismar, J. \& Kuehn, R. (2010a). Isolation and characterization of the first microsatellite markers for the endangered swan mussel Anodonta cygnea L. (Bivalvia: Unionoidea). Conservation Genetics 11, 1103-1106.

Geist, J., Söderberg, H., Karlberg, A. \& Kuehn, R. (2010b). Drainage-independent genetic structure and high genetic diversity of endangered freshwater pearl mussels (Margaritifera margaritifera) in northern Europe. Conservation Genetics 11, 1339-1350.

GeIst, J. \& KueHn, R. (2005). Genetic diversity and differentiation of central European freshwater pearl mussel (Margaritifera margaritifera L.) populations: implications for conservation and management. Molecular Ecology 14, 425-439.

Geist, J. \& Kuehn, R. (2008). Host-parasite interactions in oligotrophic stream ecosystems: the roles of life history strategy and ecological niche. Molecular Ecology 17, 997-1008.

Geist, J., Porkka, M. \& Kuehn, R. (2006). The status of host fish populations and fish species richness in European freshwater pearl mussel (Margaritifera margaritifera) streams. Aquatic Conservation: Marine and Freshwater Ecosystems 16, 251-266.

Germain, L. (1931). Fluvial and terrestrial molluscs. In Faune de France (Volume 22, ed. L. Germain). Fédération Française des Sociétés de Sciences Naturelles, Paris (in French).

Gessner, J., Williot, P., Rochard, E., Freyhof, J. \& Kottelat, M. (2010). Acipenser sturio. IUCN red list of threatened species. Version 2015.2. Available at http://www.iucnredlist.org/. Accessed 30.06.2015.

*Giribet, G., Okusu, A., Lindgren, A. R., Huff, S. W., Schrodl, M. \& Nishiguchi, M. K. (2006). Evidence for a clade composed of molluscs with serially repeated structures: monoplacophorans are related to chitons. Proceedings of the National Academy of Sciences of the United States of America 103, 7723-7728.

GŁowaciński, Z. \& Nowacki, J. (2004). Polish Red Data Book. Invertebrates. Akademia Rolnicza im. A. Cieszkowskiego and Instytut Ochrony Przyrody PAN, Poland (in Polish).

Gómez, I. \& Araujo, R. (2008). Channels and ditches as the last shelter for freshwater mussels: the case of Margaritifera auricularia and other naiads inhabiting the mid Ebro River Basin, Spain. Aquatic Conservation: Marine and Freshwater Ecosystems 18, $658-670$.

Graf, D. L. (2007). Palearctic freshwater mussel (Mollusca: Bivalvia: Unionoida) diversity and the Comparatory Method as a species concept. Proceedings of the Academy of Natural Sciences of Philadelphia 156, 71-88.

Graf, D. L. (2010). Funeral for the Nouvelle École-iana generic names introduced for freshwater mussels (Mollusca: Bivalvia: Unionoida). Proceedings of the Academy of Natural Sciences of Philadelphia 159, 1-24.

Graf, D. L. \& Cummings, K. S. (2006). Palaeoheterodont diversity (Mollusca: Trigonioida + Unionoida): what we know and what we wish we knew about freshwater mussel evolution. Zoological fournal of the Linnean Society 148, 343-394.

Graf, D. L. \& Cummings, K. S. (2007). Review of the systematics and global diversity of freshwater mussel species (Bivalvia: Unionoida). Fournal of Molluscan Studies 73, $291-314$.

Graf, D. L. \& Cummings, K. S. (2015). The freshwater mussels (Unionoida) of the world (and other less consequential bivalves). MUSSEL Project. Available at http:// mussel-project.uwsp.edu/. Accessed 30.06.2015.

Grande, C., Araujo, R. \& Ramos, M. A. (2001). The gonads of Margaritifera auricularia (Spengler, 1793) and M. margaritifera (Linnaeus, 1758) (Bivalvia: Unionoidea). Fournal of Molluscan Studies 67, 27-35. 
Grizzetti, B., Bouraoui, F., Billeen, G., Van Grinsven, H., Cardooso, A. C., Thieu, V., Garnier, J., Curtis, C., Howarth, R. \& Johnes, P. (2011). Nitrogen as a threat to European water quality. In The European Nitrogen Assessment (eds M. A. Sutton, C. M. Howard, J. W. Erisman, G. Billen, A. Bleeker, P. Grennfelt, H. V. Grinsven and B. Grizzetti), pp. 379-404. Cambridge University Press, Cambridge.

*Guindon, S. \& Gascuel, O. (2003). A simple, fast, and accurate algorithm to estimate large phylogenies by maximum likelihood. Systematic Biology 52, 696-704.

GuM, B., LANGE, M. \& GeIST, J. (2011). A critical reflection on the success of rearing and culturing juvenile freshwater mussels with a focus on the endangered freshwater pearl mussel (Margaritifera margaritifera L.). Aquatic Conservation: Marine and Freshwater Ecosystems 21, 743-751.

Gutiérrez, J. L., Jones, C. G., Strayer, D. L. \& Iribarne, O. O. (2003). Mollusks as ecosystem engineers: the role of shell production in aquatic habitats. Oikos 101, 79-90.

HAag, W. R. (2012). North American Freshwater Mussels: Natural History, Ecology, and Conservation. Cambridge University Press, Cambridge.

HAAG, W. R. \& WARren, M. L. Jr. (1997). Host fishes and reproductive biology of 6 freshwater mussel species from the Mobile Basin, USA. Fournal of the North American Benthological Society 16,576-585.

HAAG, W. R. \& WARren, M. L. Jr. (2003). Host fishes and infection strategies of freshwater mussel in large Mobile Basin streams, USA. Fournal of the North American Benthological Society 22, 78-91

HaAG, W. R. \& Williams, J. D. (2014). Biodiversity on the brink: an assessment of conservation strategies for North American freshwater mussels. Hydrobiologia 735, $45-60$.

HaAs, F. (1910). Pseudunio, a new genus for Unio sinuatus Lam. Nachrichtsblatt der Deutschen Malakozoologischen Gesellschaft 42, 181-183 (in German).

HAAs, F. (1940). A tentative classification of the palearctic unionids. Zoological Series of Field Museum of Natural History 24, 115-141.

HaAs, F. (1969). Superfamilia Unionacea. In Das Tierreich (Volume 88, ed. W. Hennig). De Gruyter, Berlin (in German).

*Hall, T. A. (1999). BioEdit: a user-friendly biological sequence alignment editor and analysis. Department of Microbiology, North Carolina State University.

Hartmann, J., Beggel, S., Auerswald, K., Stoeckle, B. \& Geist, J. (xxxx). Establishing mussel behavior as a biomarker in ecotoxicology. Aquatic Toxicology (doi: 10.1016/j.aquatox.2015.06.014) (in press).

Hastie, L. C. (2006). Determination of mortality in exploited freshwater pearl mussel (Margaritifera margaritifera) populations. Fisheries Research 80, 305-311.

Hastie, L. C., Boon, P. J., Young, M. R. \& Way, S. (2001). The effects of a major flood on an endangered freshwater mussel population. Biological Conservation 98, $107-115$

*Haukioja, E. \& Hakala, T. (1978). Life-history evolution in Anodonta piscinalis (Molusca, Pelecypoda). Oecologia 35, 253-266.

Heinricher, J. R. \& Layzer, J. B. (1999). Reproduction by individuals of a nonreproducing population of Megalonaias nervosa (Mollusca: Unionidae) following translocation. The American Midland Naturalist 141, 140-148.

Hermoso, V., Clavero, M., Blanco-Garrido, F. \& Prenda, J. (2011). Invasive species and habitat degradation in Iberian streams: an analysis of their role in freshwater fish diversity loss. Ecological Applications 21, 175-188.

Hermoso, V., Filipe, A. F., Segurado, P. \& Beja, P. (2015). Effectiveness of a large reserve network in protecting freshwater biodiversity: a test for the Iberian peninsula. Freshwater Biology 60, 698-710.

Hinzmann, M., Lopes-Lima, M., Teixeira, A., Varandas, S., Sousa, R., Lopes, A., Froufe, E. \& Machado, J. (2013). Reproductive cycle and strategy of Anodonta anatina (L., 1758): notes on hermaphroditism. Fournal of Experimental Zoology 319A. $378-390$

*Hoeh, W. R., Black, M. B., Gustafson, R., Bogan, A. E., Lutz, R. A. \& VRijenhoek, R. C. (1998). Testing alternative hypotheses of Neotrigonia (Bivalvia: Trigonioida) phylogenetic relationships using cytochrome c oxidase subunit I DNA sequences. Malacologia 40, 267-278.

Hoen, W. R., Bogan, A. E., Cummings, K. S. \& Guttman, S. I. (2002). Evolutionary relationships among the higher taxa of freshwater mussels (Bivalvia: Unionoida): inferences on phylogeny and character evolution from analyses of DNA sequence data. Malacological Review 31, 123-141.

HüBY, B. (1988). The development biology of the river mussel Pseudanodonta complanata. PhD Thesis: Institut für Zoologie der Tierärztlichen Hochschule, Hannover (in German)

Huff, S. W., Campbell, D., Gustafson, D. L., Lydeard, C., Altaba, C. R. \& GIRIBET, G. (2004). Investigations into the phylogenetic relationships of freshwater pearl mussels (Bivalvia: Margaritiferidae) based on molecular data: implications for their taxonomy and biogeography. Foumal of Molluscan Studies 70, 379-388.

Jokela, J. \& Palokangas, P. (1993). Reproductive tactics in Anodonta clams: parental host recognition. Animal Behaviour 46, 618-620.

Jokela, J., Valtonen, E. T. \& Lappalainen, M. (1991). Development of glochidia of Anodonta piscinalis and their infection of fish in a small lake in northern Finland. Archio fur Hydrobiologie 120, 345-355.
Jung, M., Scheder, C., Gumpinger, C. \& Waringer, J. (2013). Habitat traits, population structure and host specificity of the freshwater pearl mussel Margaritifera margaritifera Linnaeus 1758 in the River Waldaist (Upper Austria). Biologia 68, 922-931.

KålÅs, J. A., Viken, Å., Henriksen, S. \& SkJelseth, S. (2010). Nonwegian Red List of Species. Norwegian Biodiversity Information Centre.

Källersjö, M., Von Proschwitz, T., Lundberg, S., Eldnäs, P. \& Erséus, C. (2005). Evaluation of ITS rDNA as a complement to mitochondrial gene sequences for phylogenetic studies in freshwater mussels: an example using Unionidae from north-west Europe. Zoologica Scripta 34, 415-424.

Kantor, Y. I., Vinarski, M. V., Schileyko, A. A. \& Sysoev, A. V. (2010). Catalogue of the continental mollusks of Russia and adjacent territories. Version 2.3.1. Available at http://www.ruthenica.com. Accessed 30.06.2015.

Karlsson, S., Larsen, B. M. \& Hindar, K. (2014). Host-dependent genetic variation in freshwater pearl mussel (Margaritifera margaritifera L.). Hydrobiologia $\mathbf{7 3 5}$, $179-190$.

Khalloufi, N., Toledo, C., Machordom, A., Boumaïza, M. \& Araujo, R. (2011). The unionids of Tunisia: taxonomy and phylogenetic relationships, with redescription of Unio ravoisieri Deshayes, 1847 and U. durieui Deshayes, 1847. Fournal of Molluscan Studies 77, 103-115.

Killeen, I. \& Aldridge, D. (2011). Anodonta cygnea. IUCN red list of threatened species. Version 2015.2. Available at http://www.iucnredlist.org/. Accessed 30.06.2015.

Killeen, I., Aldridge, D. \& Oliver, G. (2004). Freshwater bivalves of Britain and Ireland. National Museum of Wales Occasional Publication 82, 1-114.

Korniushin, A. V. (2002). On the species diversity of freshwater bivalve mollusks in Ukraine and the strategy of their conservation. Vestnik Zoologii 36, 9-23 (in Russian)

Laenko, T. M. (2006). The Red Book of the Republic of Belarus. Ministry of Natural Resources and Environmental Protection of the Republic of Belarus, Minsk (in Belarusian)

Laenko, T. M. (2012). Fauna of Freshwater Molluscs of Belarus. Belarusskaya Nauka Publisher, Minsk.

Lajtner, J. \& Crnčan, P. (2011). Distribution of the invasive bivalve Sinanodonta woodiana (Lea, 1834) in Croatia. Aquatic Invasions 6, S119-S124.

Lima, P., Monteiro, S. M., Sousa, M. \& Machado, J. (2012). A histological study of oogenesis in the freshwater mussel Anodonta cygnea (Linnaeus, 1758) in Mira Lagoon, Portugal. Malacologia 55, 251-261.

Limburg, K. E. \& Waldman, J. R. (2009). Dramatic declines in North Atlantic diadromous fishes. Bioscience 59, 955-965.

Lois, S., Ondina, P., Outeiro, A., Amaro, R. \& San Miguel, E. (2014). The north-west of the Iberian Peninsula is crucial for conservation of Margaritifera margaritifera (L.) in Europe. Aquatic Conservation: Marine and Freshwater Ecosystems 24, $35-47$.

Lopes-Lima, M. (2014). Anodonta anatina. IUCN red list of threatened species. Version 2015.2. Available at http://www.iucnredlist.org/. Accessed 30.06.2015.

Lopes-Lima, M., Kebapç, U., VAn Damme, D. (2014a). Unio crassus. IUCN red list of threatened species. Version 2015.2. Available at http://www.iucnredlist.org/. Accessed 30.06.2015.

Lopes-Lima, M., Prié, V. \& Seddon, M. B. (2014b). Potomida littoralis. IUGN red list of threatened species. Version 2015.2. Available at http://www.iucnredlist.org/ Accessed 30.06.2015.

Lopes-Lima, M., Teixeira, A., Froufe, E., Lopes, A., Varandas, S. \& Sousa, R. $(2014 c)$. Biology and conservation of freshwater bivalves: past, present and future perspectives. Hydrobiologia 735, 1-13.

Lopez, M. A., Altaba, C. R., Rouault, T. \& Gisbert, E. (2007). The European sturgeon Acipenser sturio is a suitable host for the glochidia of the freshwater pearl mussel Margaritifera auricularia. Fournal of Molluscan Studies 73, 207-209.

Lydeard, C., Cowie, R. H., Ponder, W. F., Bogan, A. E., Bouchet, P., Clark, S. A., Cummings, K. S., Frest, T. J., Gargominy, O., Herbert, D. G., Hershler, R., Perez, K. E., Roth, B., Seddon, M., Strong, E. E. \& Thompson, F. G. (2004). The global decline of nonmarine mollusks. BioScience $\mathbf{5 4}$ $321-330$

Machordom, A., Araujo, R., Erpenbeck, D. \& Ramos, M. Á. (2003). Phylogeography and conservation genetics of endangered European Margaritiferidae (Bivalvia: Unionoidea). Biological fournal of the Linnean Society 78, 235-252.

Makhrov, A., Bespalaya, J., Bolotov, I., Vikhrev, I., Gofarov, M., Alekseeva, Y. \& Zotin, A. (2014). Historical geography of pearl harvesting and current status of populations of freshwater pearl mussel Margaritifera margaritifera (L.) in the western part of Northern European Russia. Hydrobiologia 735, 149-159.

*Mason-Gamer, R. J. \& Kellogg, E. A. (1996). Testing for phylogenetic conflict among molecular data sets in the tribe Triticeae (Gramineae). Systematic Biology 45, $524-545$.

McIvor, A. L. \& Aldridge, D. C. (2007). The reproductive biology of the depressed river mussel, Pseudanodonta complanata (Bivalvia: Unionidae), with implications for its conservation. Fournal of Molluscan Studies 73, 259-266.

Melnychenko, R. K., Janovich, L. N. \& Korniushin, A. V. (2001). Peculiarities of ecology and morphology of Pseudanodonta (Bivalvia, Unionidae) in the fauna of Ukraine. Vestnik Zoologii 35, 61-70 (in Russian). 
Millán, M. M., Estrela, M. J. \& Miró, J. (2005). Rainfall components: variability and spatial distribution in a Mediterranean area (Valencia Region). Fournal of Climate 18, 2682-2705.

Moorkens, E. A. \& Killeen, I. J. (2009). Database of association with habitat and environmental variables for non-shelled slugs and bivalves of Britain and Ireland. In Irish Wildlife Manuals (Volume 41, eds E. A. Moorkens and I. J. KILleEN). National Parks and Wildlife Service, Department of the Environment, Heritage and Local Government, Dublin.

Morales, J. J., Negro, A. I., Lizana, M., Martínez, A. \& Palacios, J. (2004). Preliminary study of the endangered populations of pearl mussel Margaritifera margaritifera (L.) in the River Tera (north-west Spain): habitat analysis and management considerations. Aquatic Conservation: Marine and Freshwater Ecosystems 14, 587-596.

Мотте, G. (2012). Life nature project Nature/B/8590 Final report 2012, art 17. Belgium.

Mouthon, J. \& Daufresne, M. (2006). Effects of the 2003 heatwave and climatic warming on mollusc communities of the Saône: a large lowland river and of its two main tributaries (France). Global Change Biology 12, 441-449.

Mueller, M., Pander, J. \& Geist, J. (2011). The effects of weirs on structural stream habitat and biological communities. Fournal of Applied Ecology 48, $1450-1461$.

NAGEL, K.-O. (2004). Observations on the reproductive period of the freshwater mussel Potomida littoralis (Unionidae). Iberus 22, 1-8.

Nagel, K.-O. \& Badino, G. (2001). Population genetics and systematics of European Unionoidea. In Ecology and Evolution of the Freshwater Mussels Unionoida (eds G. BAUER and K. WÄCHTLER), pp. 51-80. Springer-Verlag, Heidelberg.

Nagel, K.-O., Badino, G. \& Alessandria, B. (1996). Population genetics of European Anodontinae (Bivalvia: Unionidae). Gournal of Molluscan Studies 62, $343-357$.

Nagel, K.-O., Badino, G. \& Celebrano, G. (1998). Systematics of European naiades (Bivalvia: Margaritiferidae and Unionidae): a review and some new aspects. Malacological Review 31, 83-104.

Nagel, K.-O. \& Castagnolo, L. (1991). Fish hosts for the glochidium of Unio mancus. Rivista di Idrobiologia 30, 339-346.

Nagel, K.-O., Castagnolo, L., Cencetti, E. \& Moro, G. A. (2007). Notes on reproduction, growth and habitat of Microcondylaea bonellii (Mollusca: Bivalvia: Unionidae) in the torrente Versa (Italy). Mollusca 25, 41-49.

Negus, C. L. (1966). A quantitative study of growth and production of unionid mussels in the River Thames at Reading. Fournal of Animal Ecology 35, 513-532.

Niemeyer, B. (1993). Comparative studies on the bionomic strategy of the freshwater mussels Anodonta cygnea $L$. and Anodonta anatina $L$. PhD Thesis: Universität Hannover (in German).

Nienhuis, J. A. (2003). The rediscovery of Spengler's freshwater pearl mussel Pseudunio auricularius (Spengler, 1793) (Bivalvia, Unionoidea, Margaritiferidae) in two river systems in France, with an analysis of some factors causing its decline. Basteria 67, $67-86$.

Ortmann, A. E. (1911). The classification of the European Naiades. The Nautilus 25, $5-7$.

Österling, M. E., Arvidsson, B. L. \& Greenberg, L. A. (2010). Habitat degradation and the decline of the threatened mussel Margaritifera margaritifera: influence of turbidity and sedimentation on the mussel and its host. Fournal of Applied Ecology 47, 759-768.

Österling, M. E. \& LARSEN, B. M. (2013). Impact of origin and condition of host fish (Salmo trutta) on parasitic larvae of Margaritifera margaritifera. Aquatic Conservation: Marine and Freshwater Ecosystems 23, 564-570.

Ostrovsky, A. N. \& Popov, I. Y. (2011). Rediscovery of the largest population of the freshwater pearl mussel (Margaritifera margaritifera) in the Leningrad oblast (North-West Russia). Aquatic Conservation: Marine and Freshwater Ecosystems 21, 113-121.

Oulasvirta, P. (2011). Distribution and status of the freshwater pearl mussel Margaritifera margaritifera in northern Fennoscandia. Toxicological and Environmental Chemistry 93, 1713-1730.

Ożgo, M. \& Abraszewska, A. (2009). The importance of peat excavation water bodies for biodiversity and conservation: a case of the three Unionidae (Bivalvia) mussel species. Polish fournal of Ecology 57, 793-798.

*Palumbi, S., Martin, A., Romano, S., Mcmillan, W., Stick, L. \& Grabowski, G. (2002). The simple fools guide to PCR. Version 2, Honolulu.

PANDER, J. \& GEIST, J. (2013). Ecological indicators for stream restoration success. Ecological Indicators 30, 106-118.

PATZner, R. A. \& MüLler, D. (2001). Effects of eutrophication on unionids. In Ecology and Evolution of the Freshwater Mussels Unionoida (eds G. BAUER and K. WÄCHTLER), pp. 327-335. Springer-Verlag, Heidelberg.

Pekrarinen, M. (1993). Reproduction and condition of unionid mussels in the Vantaa River, South Finland. Archiv für Hydrobiologie 127, 357-375.

Piechocki, A. (1999). Reproductive biology of Unio pictorum (Linnaeus) and U. tumidus PHILIPSSON in the Pilica River (Central Poland). Heldia 4, 53-60.

Prí́, V. (2010). Margaritifera auricularia. IUCN red list of threatened species. Version 2015.2. Available at http://www.iucnredlist.org/. Accessed 30.06.2015.
Prié, V., Molina, Q. \& Gamboa, B. (2014). French naiad (Bivalvia: Margaritiferidae, Unionidae) species distribution models: prediction maps as tools for conservation. Hydrobiologia 735, 81-94.

Prié, V. \& Puillandre, N. (2014). Molecular phylogeny, taxonomy, and distribution of French Unio species (Bivalvia, Unionidae). Hydrobiologia 735, 95-110.

Prié, V., Puillandre, N. \& Bouchet, P. (2012). Bad taxonomy can kill: molecular reevaluation of Unio mancus Lamarck, 1819 (Bivalvia: Unionidae) and its accepted subspecies. Knowledge and Management of Aquatic Ecosystems 405, 08p1-08p18.

Pusch, M., Siefert, J. \& Walz, N. (2001). Filtration and respiration rates of two unionid species and their impact on water quality of a lowland river. In Ecology and Evolution of the Freshwater Mussels Unionoida (eds G. BAUER and K. WÄCHTLER), pp. 317-326. Springer-Verlag, Heidelberg.

Pynnönen, K. (1995). Effect of $\mathrm{pH}$, hardness and maternal pre-exposure on the toxicity of $\mathrm{Cd}, \mathrm{Cu}$ and $\mathrm{Zn}$ to the glochidial larvae of a freshwater clam Anodonta cygnea. Water Research 29, 247-254.

*Rambaut, A. \& Drummond, A. J. (2007). Tracer v1.4. Available at http://beast bio.ed.ac.uk/Tracer Accessed 30.06.2015

Rassi, P., Hyvärinen, E., Juslén, A. \& Mannerkoski, I. (2010). Red List of Finnish Species. Ministry of the Environment and Finnish Environment Institute, Helsinki (in Finnish).

REIS, J. (2003). The fresh water pearl mussel Margaritifera margaritifera (L.) (Bivalvia, Unionoida) rediscovered in Portugal and threats to its survival. Biological Conservation 114, $447-452$.

ReIs, J. \& Araujo, R. (2009). Redescription of Unio tumidiformis Castro, 1885 (Bivalvia, Unionidae), an endemism from the south-western Iberian Peninsula. Fournal of Natural History 43, 1929-1945.

Reis, J., Collares-Pereira, M. J. \& Araujo, R. (2014). Host specificity and metamorphosis of the glochidium of the freshwater mussel Unio tumidiformis (Bivalvia: Unionidae). Folia Parasitologica 61, 81-89.

Reis, J., Machordom, A. \& Araujo, R. (2013). Morphological and molecular diversity of unionidae (Mollusca, Bivalvia) from Portugal. Graellsia 69, 17-36.

Reischütz, A. \& Reischütz, L. P. (2007). Austria red list of molluscs. In Red List of Endangered Animals of Austria (part 2; eds K. P. ZuLKA), pp. 363-433. Böhlau Verlag, Wien (in German).

Rizhinashvili, A. L. (2009). Determination of maximum lifespan of Bivalves as exemplified by Unio-like mussels (Bivalvia, Unionidae). Doklady Biological Sciences 424, 3-6 (in Russian).

*Ronquist, F. \& Huelsenbeck, J. P. (2003). MrBayes 3: Bayesian phylogenetic inference under mixed models. Bioinformatics 19, 1572-1574.

Rudzīte, M., Dreijers, E., Ozolina-Moll, L., Parele, E., Pilāte, D., Rudzītis, M. \& Stalažs, A. (2010). A Guide to the Molluscs of Latvia. LU Akadēmiskais apgāds, Rīga.

Rüetschi, J., Stucki, P., Mülleer, P., Vicentini, H. \& Claude, F. (2011). Red List: Molluscs (snails and bivalves): Switzerland Threatened Species Status in 2010. Office Fédéral de l'Environnement, Berne, et Centre Suisse de Cartographie de la Faune, Neuchâtel (in French).

SAARINEN, M. \& TASKINEN, J. (2003). Burrowing and crawling behaviour of three species of Unionidea in Finland. Fournal of Molluscan Studies 69, 81-86.

*Sambrook, J., Fritsch, E. F. \& Maniatis, T. (1989). Molecular Cloning: A Laboratory Manual. Cold Spring Harbour Press, New York.

San Miguel, E. S., Monserrat, S., Fernández, C., Amaro, R., Hermida, M., Ondina, P. \& Altaba, C. R. (2004). Growth models and longevity of freshwater pearl mussels (Margaritifera margaritifera) in Spain. Canadian Fournal of Zoology 82, $1370-1379$.

Santos, R. M. B., Sanches Fernandes, L. F., Varandas, S. G. P., Pereira, M. G., Sousa, R., Teixeira, A., Lopes-Lima, M., Cortes, R. M. V. \& Pacheco, F. A. L. (2015). Impacts of climate change and land-use scenarios on Margaritifera margaritifera, an environmental indicator and endangered species. Science of the Total Environment 511, 477-488.

SÁrkÁNY-KISS, A. (2003). Past and present status of the aquatic mollusk fauna in Transylvanian rivers. Ecological interpretation of qualitative and quantitative dynamics, proposals. In Transylvania Rivers in the Natural State (ed. L. UJvárosi), pp. 107-150. Sapientia Könyvek, Természettudomány, Kolozsvár (in Hungarian).

Scheder, C., Gumpinger, C. \& Csar, D. (2011). Application of a five-stage field key for the larval development of the freshwater pearl mussel (Margaritifera margaritifera Linné, 1758) under different temperature conditions - a tool for the approximation of the optimum time for host fish infection in captive breeding. Ferrantia 64, $13-22$.

Seddon, M. B., Killeen, I. J. \& Fowles, A. P. (2014). A Review of the Non-Marine Mollusca of Great Britain: Species. Countryside Council for Wales, Bangor.

Skidmore, R., Leach, C., Hoffman, J., Amos, W. \& Aldridge, D. (2010). Conservation genetics of the endangered depressed river mussel, Pseudanodonta complanata, using amplified fragment length polymorphism (AFLP) markers. Aquatic Conservation: Marine and Freshwater Ecosystems 20, 560-567. 
Smith, D. G. (2001). Systematics and distribution of the recent Margaritiferidae. In Ecology and Evolution of the Freshwater Mussels Unionoida (eds G. BAUER and K. WÄCHTLER), pp. 33-49. Springer-Verlag, Heidelberg.

Sousa, R., Amorim, A., Froufe, E., Varandas, S., Teixeira, A. \& Lopes-Lima, M. (2015). Conservation status of the freshwater pearl mussel Margaritifera margaritifera in Portugal. Limnologica 50, 4-10.

Sousa, R., Amorim, A., Sobral, C., Froufe, E., Varandas, S., Teixeira, A. \& Lopes-Lima, M. (2013). Ecological status of a Margaritifera margaritifera (Linnaeus, 1758) population at the southern edge of its distribution (River Paiva, Portugal). Environmental Management 52, 1230-1238.

Sousa, R., Dias, S., Guilhermino, L. \& Antunes, C. (2008). Minho River tidal freshwater wetlands: threats to faunal biodiversity. Aquatic Biology 3, $237-250$

Sousa, R., Novais, A., Costa, R. \& Strayer, D. (2014). Invasive bivalves in fresh waters: impacts from individuals to ecosystems and possible control strategies. Hydrobiologia 735, 233-251

Sousa, R., Pilotto, F. \& Aldridge, D. C. (2011). Fouling of European freshwater bivalves (Unionidae) by the invasive zebra mussel (Dreissena polymorpha). Freshwater Biology 56, 867-876.

Sousa, R., Varandas, S., Cortes, R., Teixeira, A., Lopes-Lima, M., Machado, J. \& Guilhermino, L. (2012). Massive die-offs of freshwater bivalves as resource pulses. Annales de Limnologie-International fournal of Limnology 48, 105-112.

Spooner, D. E., Frost, P. C., Hillebrand, H., Arts, M. T., Puckrin, O. \& Xenopoulos, M. A. (2013). Nutrient loading associated with agriculture land use dampens the importance of consumer-mediated niche construction. Ecology Letters 16, 1115-1125.

Spuris, Z. (1998). Red Data Book of Latvia, Rare and Threatened Species of Plants and Animals, Invertebrates (Volume 4). LU Biologijas institūts, Riga (in Latvian).

ŠTEFFEK, J. (1994). Current status of the molluscs of Slovakia in relation to their exposure to danger. Biologia Series B 49,651-655.

Sternecker, K., Cowley, D. E. \& Geist, J. (2013). Factors influencing the success of salmonid egg development in river substratum. Ecology of Freshwater Fish 22, $322-333$.

STERnecker, K. \& Geist, J. (2010). The effects of stream substratum composition on the emergence of salmonid fry. Ecology of Freshwater Fish 19, 537-544.

Stoeckl, K., Taeubert, J.-E. \& GeIst, J. (2015). Fish species composition and host fish density in streams of the thick-shelled river mussel (Unio crassus) - implications for conservation. Aquatic Conservation: Marine and Freshwater Ecosystems 25, 276-287.

Strayer, D. L. (2008). Freshwater Mussel ecology: A Multifactor Approach to Distribution and Abundance. University of California Press, London.

Strayer, D. L., Caraco, N. F., Cole, J. J., Findlay, S. \& Pace, M. L. (1999). Transformation of freshwater ecosystems by bivalves. BioScience 49, 19-27.

Strayer, D. L., Downing, J. A., Haag, W. R., King, T. L., Layzer, J. B., Newton, T. J. \& Nichols, S. J. (2004). Changing perspectives on pearly mussels, North America's most imperiled animals. BioScience 54, 429-439.

Strayer, D. L. \& Malcom, H. M. (2007). Effects of zebra mussels (Dreissena polymorpha) on native bivalves: the beginning of the end or the end of the beginning? Fournal of North American Benthological Society 26, 111-122.

Strayer, D. L. \& Malcom, H. M. (2012). Causes of recruitment failure in freshwater mussel populations in southeastern New York. Ecological Applications 22, $1780-1790$.

Taeubert, J.-E., Denic, M., Gum, B., Lange, M. \& Geist, J. (2010). Suitability of different salmonid strains as hosts for the endangered freshwater pearl mussel (Margaritifera margaritifera). Aquatic Conservation: Marine and Freshwater Ecosystems 20 , $728-734$

TAeubert, J.-E., El-Nobi, G. \& Geist, J. (2014). Effects of water temperature on the larval parasitic stage of the thick-shelled river mussel (Unio crassus). Aquatic Conservation: Marine and Freshwater Ecosystems 24, 231-237.

Taeubert, J.-E., Gum, B. \& Geist, J. (2012a). Host-specificity of the endangered thick-shelled river mussel (Unio crassus, Philipsson 1788) and implications for conservation. Aquatic Conservation: Marine and Freshwater Ecosystems 22, 36-46.

TAeubert, J.-E., GuM, B. \& Geist, J. (2013). Variable development and excystment of freshwater pearl mussel (Margaritifera margaritifera L.) at constant temperature. Limnologica 43, 319-322.

Taeubert, J.-E., Martinez, A. M. P., Gum, B. \& Geist, J. (2012b). The relationship between endangered thick-shelled river mussel (Unio crassus) and its host fishes. Biological Conservation 155, 94-103.

Tankersley, R. \& Dimock, R. V. (1993). The effect of larval brooding on the respiratory physiology of the freshwater unionid mussel Pyganodon cataracta. American Midland Naturalist 130, 146-163.

Taskinen, J., Berg, P., Saarinen-Valta, M., Välilä, S., Mäenpää, E., Myllynen, K. \& Pakkala, J. (2011). Effect of pH, iron and aluminum on survival of early life history stages of the endangered freshwater pearl mussel, Margaritifera margaritifera. Toxicological and Environmental Chemistry 93, $1764-1777$.

Taskinen, J., Mäkelä, T. \& Valtonen, E. T. (1997). Exploitation of Anodonta piscinalis (Bivalvia) by trematodes: parasite tactics and host longevity. Annales Zoologici Fennici 34, 37-46.
Taskinen, J. \& Valtonen, E. T. (1995). Age-, size- and sex-specific infection of Anodonta piscinalis (Bivalvia, Unionidae) with Rhipidocotyle fennica (Digenea, Bucephalidae) and its influence on host reproduction. Canadian Fournal of Zoology 73, 887-897.

TudoranceA, C. (1972). Studies on Unionidae populations from the Crapina-Jijila complex of pools (Danube zone liable to inundation). Hydrobiologia 39, $527-561$.

Van Damme, D. (2011a). Pseudanodonta complanata. IUCN red list of threatened species. Version 2015.2. Available at http://www.iucnredlist.org/. Accessed 30.06.2015.

Van Damme, D. (2011b). Unio pictorum. IUGN red list of threatened species. Version 2015.2. Available at http://www.iucnredlist.org/. Accessed 30.06.2015.

Van Damme, D. (2011c). Unio tumidus. IUCN red list of threatened species. Version 2015.2. Available at http://www.iucnredlist.org/. Accessed 30.06.2015.

Varandas, S., Lopes-Lima, M., Teixeira, A., Hinzmann, M., Reis, J., Cortes, R., Machado, J. \& Sousa, R. (2013). Ecology of southern European pearl mussels (Margaritifera margaritifera): first record of two new populations on the rivers Terva and Beça (Portugal). Aquatic Conservation: Marine and Freshwater Ecosystems 23, $374-389$.

Vaughn, C. C. \& Hakenkamp, C. C. (2001). The functional role of burrowing bivalves in freshwater ecosystems. Freshwater Biology 46, 1431-1446.

Vaughn, C. C. \& TAYlor, C. M. (1999). Impoundments and the decline of freshwater mussels: a case study of an extinction gradient. Conservation Biology 13, 912-920.

VAughn, C. C. \& TAYlor, C. M. (2000). Macroecology of a host-parasite relationship. Ecography 23, 11-20.

Verdú, J. Y. G. \& Galante, E. E. (2006). Spanish Red Book of Invertebrates. Dirección General Biodiversidad, Ministerio de Medio Ambiente, Madrid (in Spanish).

Vicentini, H. (2005). Unusual spurting behaviour of the freshwater mussel Unio crassus. Fournal of Molluscan Studies 71, 409-410.

Vicentini, H. \& Pfändler, U. (2001). The river mussel Unio crassus (Philipsson 1788) in Seegraben, Canton of Schaffhausen. Mitteilungen der Naturforschenden Gesellschaft Schaffhausen 46, 85-100 (in German).

Von Proschwitz, T., Lundberg, S. \& Bergengren, J. (2006). A Guide to the Swedish Freshwater Mussels. Länsstyrelsen i Jönköpings län, Naturhistoriska riksmuseet, Göteborgs Naturhistoriska Museum, Sweden (in Swedish).

Wächtler, K., Dreher-Mansur, M. C. \& Richter, T. (2001). Larval types and early postlarval biology in naiads (Unionoida). In Ecology and Evolution of the Freshwater Mussels Unionoida (eds G. Bauer and K. WÄChtLER), pp. 93-125. Springer-Verlag, Heidelberg.

*Walker, J. M., Bogan, A. E., Bonfiglio, E. A., Campbell, D. C., Christian, A. D., Curole, J. P., Harris, J. L., Wojtecki, R. J. \& Hoeh, W. R. (2007). Primers or amplifying the hypervariable, male-transmitted COII-COI junction region in amblemine freshwater mussels (Bivalvia: Unionoidea: Ambleminae). Molecular Ecology Notes 7, 489-491.

*Walker, J. M., Curole, J. P., Wade, D. E., Chapman, E. G., Bogan, A. E. \& Watters, G. T. (2006). Taxonomic distribution and phylogenetic utility of gender-associated mitochondrial genomes in the Unionoida (Bivalvia). Malacologia 48, 265-282.

Watters, G. T. (1996). Small dams as barriers to freshwater mussels (Bivalvia, Unionoida) and their hosts. Biological Conservation 75, 79-85.

Weber, E. (2005). Population size and structure of three mussel species (Bivalvia: Unionidae) in a northeastern German river with special regard to influences of environmental factors. Hydrobiologia 537, 169-183.

Whelan, N. V., Geneva, A. J. \& GRAF, D. L. (2011). Molecular phylogenetic analysis of tropical freshwater mussels (Mollusca: Bivalvia: Unionoida) resolves the position of Coelatura and supports a monophyletic Unionidae. Molecular Phylogenetics and Evolution 61, 504-514.

Williams, J. D., Warren, M. L. Jr., Cummings, K. S., Harris, J. L. \& Neves, R. J. 1993). Conservation status of freshwater mussels of the United States and Canada. Fisheries 18, 6-22.

Wood, E. M. (1974). Development and morphology of the glochidium larva of Anodonta cygnea (Mollusca: Bivalvia). Fournal of Zoology 173, 1-13.

YounG, M. R. (1991). Conserving the freshwater pearl mussel (Margaritifera margaritifera L.) in the British Isles and continental Europe. Aquatic Conservation: Marine and Freshwater Ecosystems 1, 73-77.

Young, M. R., Cosgrove, P. J. \& Hastie, L. C. (2001). The extent of, and causes for, the decline of a highly threatened naiad: Margaritifera margaritifera. In Ecology and Evolution of the Freshwater Mussels Unionoida (eds G. BAUER and K. WÄCHTLER), pp. 337-357. Springer-Verlag, Heidelberg.

Zahner-Meike, E. \& Hanson, J. M. (2001). Effect of muskrat predation on naiads. In Ecology and Evolution of the Freshwater Mussels Unionoida (eds G. BAUER and K. WÄCHTLER), pp. 163-184. Springer-Verlag, Heidelberg.

ZAJAC, K. \& ZAJAC, T. (2011). The role of active individual movement in habitat selection in the endangered freshwater mussel Unio crassus Philipsson 1788. Fournal of Conchology 40, 446-461.

Zajac, K., Zajac, T., Adamski, P., Bielański, W., Ćmiel, A. \& Lipińska, A (2013). How to establish a new population of Unio crassus? A case study in the Biała River. Açoreana, Supplement 8, 212-213. 
Zhadin, V. I. (1952). Mollusks of Fresh and Brackish Waters of the USSR. Academy of Sciences of the USSR, Israeli Program for Scientific Translations, Jerusalem.

Zieritz, A. \& Aldridge, D. G. (2011). Sexual, habitat-constrained and parasite-induced dimorphism in the shell of a freshwater mussel (Anodonta anatina, Unionidae). Joumal of Morphology 272, 1365-1375.

Zieritz, A., Gum, B., Kuehn, R. \& Geist, J. (2012). Identifying freshwater mussels (Unionoida) and parasitic glochidia larvae from host fish gills: a molecular key to the North and Central European species. Ecology \& Evolution 2, $740-750$.

Zieritz, A., Hoffman, J. I., Amos, W. \& Aldridge, D. C. (2010). Phenotypic plasticity and genetic isolation-by-distance in the freshwater mussel Unio pictorum (Mollusca: Unionoida). Evolutionary Ecology 24, 923-938.

Ziuganov, V., Zotin, A., Nezlin, L. \& Tretiakov, V. (1994). The Freshwater Pearl Mussels and Their Relationships with Salmonid Fish. VNIRO Publishing, Moscow.

\section{SUPPORTING INFORMATION}

Additional supporting information may be found in the online version of this article.

Appendix S1. Genetic sequences table and methodology.

Appendix S2. Distribution data bibliography.

Appendix S3. Biological traits bibliography.

Appendix S4. Principal habitats bibliography.

Appendix S5. Conservation and protection status bibliography.

(Received 31 January 2015; revised 4 November 2015; accepted 9 November 2015; published online 4 January 2016) 